\title{
How Long Can the Unsustainable U.S. Current Account Deficit Be Sustained?
}

\author{
Carol Bertaut, Steve Kamin, and Charles Thomas*
}

May 30, 2008

\begin{abstract}
This paper addresses three questions about the prospects for the U.S. current account deficit. Is it sustainable in the long term? If not, how long will it take for measures of external debt and debt service to reach levels that could prompt some pullback by global investors? And if and when such levels are breached, how readily would asset prices respond and the current account start to narrow?

To address these questions, we start with projections of a detailed partial-equilibrium model of the U.S. balance of payments. Based on plausible assumptions of the key drivers of the U.S. external balance, they indicate that the current account deficit will resume widening and the negative NIIP/GDP ratio will continue to expand. However, our projections suggest that even by the year 2020, the negative NIIP/GDP ratio will be no higher than it is in several industrial economies today, and U.S. net investment income payments will remain very low. The share of U.S. claims in foreigners' portfolios will likely rise, but not to an obviously worrisome extent. All told, it seems likely it would take many years for the U.S. debt to cumulate to a level that would test global investors' willingness to extend financing.

Finally, we explore the historical responsiveness of asset prices and the current account in industrial economies to measures of external imbalances and debt. We find little evidence that, as countries' net indebtedness rises, the developments needed to correct the current accountincluding changes in growth rates, asset prices, or exchange rates - materialize all that rapidly. We would emphasize that these findings do not imply that U.S. current account adjustment is necessarily many years away, as any number of factors could trigger such adjustment. Our point is rather that international balance sheet considerations likely are not sufficient, by themselves, to require external adjustment any time soon.
\end{abstract}

*The authors are economists in the International Finance Division of the Federal Reserve Board. They can be reached at carol.bertaut@frrb.gov, steven.kamin@frb.gov , and charles.thomas@frb.gov. This paper has benefitted from comments by Trevor Reeve and participants at the Current Account Sustainability in Major Economies (II) conference at the University of Wisconsin, especially our discussant Jeffrey Frankel. The views in this paper are solely the responsibility of the authors and should not be interpreted as reflecting the views of the Board of Governors of the Federal Reserve System or of any other person associated with the Federal Reserve System. Jim Albertus, Sean Fahle and Dao Nguyen provided excellent research assistance. 


\section{Introduction and Summary}

Several years ago, as the U.S. current account deficit was expanding to record levels, observers increasingly began to focus on the unsustainability of the U.S. external imbalances, as well as the possibility that the subsequent correction would be abrupt and disorderly. ${ }^{1}$ Since peaking at 6.6 percent of GDP in the third quarter of 2006, however, the current account deficit has begun shrinking as a result of declines in the foreign exchange value of the dollar, slower U.S. GDP growth, and continued strong expansion abroad; the deficit dipped to 4.9 percent in the fourth quarter of 2007. With the reduction in the deficit and the depreciation of the dollar, which in real multilateral terms is now about 25 percent below its peak level in February 2002, concerns about a disorderly correction appear to have become less prominent. This may in part reflect a growing conviction that a correction of the current account is likely to be orderly rather than disruptive. ${ }^{2}$ It may also reflect a view that, with recent declines in the dollar and in the deficit, no further correction of the U.S. current account may be necessary.

In this paper, we address three simple questions: Is the U.S. current account now sustainable on a long-term basis? If not, how long might it take for measures of U.S. external indebtedness to expand beyond levels that global investors are willing to finance? And finally, if and when such levels are breached, how rapidly might a correction in asset prices and the current account ensue?

We start, in Section II, by discussing the most common metric for assessing current account sustainability, the stability of an economy's net debt as a share of GDP; such stability is necessary if net interest payments to foreigners are not to rise without limit as a share of income.

\footnotetext{
${ }^{1}$ See, among others, Edwards (2005), Eichengreen (2004), Mann (1999, 2002, 2003), Mussa (2004), Obstfeld and Rogoff (2004), Roubini and Setzer (2004), and Truman (2004).

${ }^{2}$ Freund (2005), Croke, Kamin, and Leduc (2006), Gagnon (2005), and Debelle and Galati (2005), among others, present evidence suggesting that current account corrections in industrial economies have generally been benign.
} 
We go on in Section III to describe projections of U.S. external balance variables and measure them against the sustainability criterion described above. The projections are based on simulations of a detailed model of the U.S. balance of payments, taking as exogenous the key drivers of the U.S. trade and current accounts: GDP growth in the United States and abroad, inflation rates, interest rates, oil prices, and the level of the real multilateral dollar. We find that, based on our model simulations, beyond the near term, the current account deficit likely will begin widening again and U.S. external debt will rise steadily.

However, just because the current account is unsustainable in the long term does not mean that a correction is imminent. Theory provides no guidance as to how large the external debt must become before developments are triggered that would narrow the U.S. current account deficit. Our baseline projection suggests that the U.S. net external debt will grow from around 20 percent of GDP at present to around 60 percent of GDP by 2020 . Is that a lot or a little? To answer this question, we look to the current pattern of external liabilities among industrial countries, and we find a number of countries whose external debt ratios currently are 60 percent or higher.

The net debt/GDP ratio, while a common and useful summary measure of an economy's international balance-sheet situation, is not a perfect or unique indicator of a country's creditworthiness. Accordingly, in Section IV, we consider a second metric of current account sustainability: the exposure of investors to U.S. assets in terms of the share of U.S. securities in foreign portfolios. If the financing of the current account deficit means that this exposure is rising without limit, that, too, would suggest that the current account is unsustainable. We find no evidence that, to date, the exposure of foreign investors to U.S. assets has been rising. Calculations based on our projections of the U.S. balance of payments (described above) suggest that this exposure will increase going forward, but not necessarily to a worrisome extent. 
All told, the evidence we present in Sections III and IV suggests that, even in the absence of further changes in the driving variables, it would likely be many years before indicators of the U.S. international balance sheet breached any significant thresholds of creditworthiness and investor exposure. Yet, if such thresholds were breached, do we know how rapidly forces would be set in motion to narrow the current account deficit and restrain the growth of external debt? To address this question, Section $\mathrm{V}$ examines the extent to which, historically, higher levels of external debt or related imbalances have led to changes in an economy's access to financing. We first examine the effect of external debt on two variables that closely reflect the behavior of global investors: interest rates and exchange rates. Estimating panel regressions for a sample of industrial countries, we find that higher levels of debt push up interest rates in a country by only a very small extent, and exert no discernable effect on exchange rates. We then reproduce recent results by Gruber and Kamin (2008), who find that in panel regressions to explain the current account balance, the lagged value of the net international investment position (NIIP) invariably has a positive and significant coefficient; this suggests that higher levels of debt lead to larger, not smaller, current account deficits. Section VI summarizes our findings and advances some tentative conclusions.

\section{Assessing Current Account Sustainability}

\section{II.1 The NIIP/GDP criterion}

The net international investment position (NIIP) represents the sum of all claims by U.S. residents on foreign residents less the claims of foreigners on the United States. The NIIP is a key determinant (along with rates of return) of U.S. net investment income: the sum of receipts on foreign assets owned by U.S residents net of payments on foreign claims on U.S. residents. Therefore, most analysts underscore that a necessary condition for current account sustainability 
is that the NIIP/GDP ratio be stable (Mann, 1999, 2002, 2003, Mussa, 2004, Cline, 2005, Edwards, 2005). Otherwise, if the (negative) NIIP/GDP ratio were to rise without limit, the ratio of net investment payments to GDP would rise as well, and would eventually exceed GDP.

Unrestrained increases in the (negative) NIIP/GDP ratio beyond some threshold should set in train a number of developments that would narrow the current account deficit and restrain the growth of external debt: U.S. residents would reduce their spending as their wealth declined and they experienced an erosion of the amount of disposable income remaining after servicing their debt. And foreigners would sell off U.S. assets as they became concerned about our ability to repay debts, weakening the dollar and thus again leading to smaller deficits.

The stability of the NIIP/GDP ratio required for current account sustainability, in turn, imposes limits on the current account deficit. To see this, note that for the ratio of the NIIP to GDP to remain stable over time, the proportionate change in the NIIP must equal the proportionate rise in nominal GDP:

$$
\left(\mathrm{NIIP}_{\mathrm{t}}-\mathrm{NIIP}_{\mathrm{t}-1}\right) / \mathrm{NIIP}_{\mathrm{t}-1}=\left(\mathrm{GDP}_{\mathrm{t}}-\mathrm{GDP}_{\mathrm{t}-1}\right) / \mathrm{GDP}_{\mathrm{t}-1}
$$

Leaving aside any valuation adjustments, the annual change in the NIIP is equal to the current account balance:

$$
\text { NIIP }_{t}-\text { NIIP }_{t-1}=\text { Current Account } t
$$

Therefore the proportionate change in the NIIP is equal to the ratio of the current account to the lagged NIIP; this, in turn, approximately equals the current account/GDP ratio divided by the NIIP/GDP ratio:

$$
\begin{aligned}
\left(\mathrm{NIIP}_{\mathrm{t}}-\mathrm{NIIP}_{\mathrm{t}-1}\right) / \mathrm{NIIP}_{\mathrm{t}-1} & =\left(\text { Current Account } / \mathrm{NIIP}_{\mathrm{t}-1}\right) \\
& \approx\left(\text { Current Account } t / \mathrm{GDP}_{\mathrm{t}}\right) /\left(\mathrm{NIIP}_{\mathrm{t}} / \mathrm{GDP}_{\mathrm{t}}\right)
\end{aligned}
$$


Accordingly, for the ratio of the NIIP to GDP to remain stable over time, the current account/GDP ratio divided by the NIIP/GDP ratio must equal the proportionate rise in nominal GDP:

(Current Account $\left./ \mathrm{GDP}_{\mathrm{t}}\right) /\left(\mathrm{NIIP}_{\mathrm{t}} / \mathrm{GDP}_{\mathrm{t}}\right) \approx\left(\mathrm{GDP}_{\mathrm{t}}-\mathrm{GDP}_{\mathrm{t}-1}\right) / \mathrm{GDP}_{\mathrm{t}}$

In 2007, the current account deficit was about 5 percent of GDP and the NIIP was about 18 percent of GDP. This implies, all else held constant, that the NIIP would rise (become more negative) at a pace of 28 percent annually, much faster than the prospective rate of increase of nominal GDP of 4.4 percent (see Section III). Were the current account deficit to remain at 5 percent of GDP, the NIIP/GDP ratio would stabilize once it reached -114 percent. $^{3}$ This is because at that level of the NIIP, the proportionate rise in the NIIP-5 percent/114 percent-is equal to the prospective 4.4 percent rise in nominal GDP. How large a negative NIIP/GDP ratio is sustainable? Nobody knows, but some relevant considerations are discussed in Section III.4.

\section{II.2 Qualifications to the NIIP as a measure of external sustainability}

The NIIP does not fully summarize the sustainability of the external position. As will be discussed further below, depending upon the rate of return, the same NIIP may be associated with very different net investment income flows. Several additional considerations also affect the interpretation of the NIIP as a measure of creditworthiness and sustainability.

First, changes in the valuation of assets may affect the NIIP without affecting the economy's underlying capacity to service the external position. For example, all else equal, a rise in U.S. stock prices will raise the value of foreign holdings of U.S. assets and thus cause the NIIP to become more negative. However, this does not necessarily mean that the U.S. external

\footnotetext{
${ }^{3}$ This discussion leaves open the question of what level of the trade balance would be needed to achieve the level of the current account required to stabilize the NIIP/GDP ratio. One rule of thumb is that current account stability requires the trade balance to be equal to zero; then, the current account equals net income payments on the NIIP, the NIIP grows at the rate of interest, and, if GDP grows at the rate of interest as well, the NIIP/GDP ratio is stabilized.
} 
position has become more difficult to finance. On the contrary, the higher stock prices may reflect increases in U.S. income and productivity, raising our capacity to make foreign payments; moreover, higher stock prices mean we can finance the same current account deficit through the sale of fewer (but pricier) equities to foreigners.

An extreme example of the impact of equity valuations on the NIIP is Finland, where a substantial share of its external liabilities consists of foreign holdings of stock in Nokia. As shown in the top panel of Exhibit 1, the surge in the NIIP to nearly -170 percent of GDP in 1999 was driven by a parallel surge in the price of Nokia stock, and when that stock declined, so, too, did the size of Finland's negative NIIP.

Second, and as a related point, one should not confuse the NIIP with the net wealth of an economy's residents. Net wealth is comprised of total assets owned by residents, both domestic and foreign, less foreigners' claims on those residents. The bottom panel of Exhibit 1 compares the net wealth of U.S. residents to the NIIP (expressed as a liability position) and total gross claims on U.S. residents, including foreign direct investment in the United States. (It is important to note that in this measure of net wealth the foreign claims, or net liabilities, have already been netted out.) As the chart illustrates, relative to net wealth both the U.S. net debt position and the gross claims of foreigners remain relatively small. ${ }^{4}$ Presumably, a country's ability to repay external debt will depend not only on its GDP, but also on its total wealth, just as a homeowner's ability to repay his mortgage depends not just on his income, but on the value of his assets including, but not limited to, his house. Accordingly, increases in net external debt accompanied by even larger increases in the value of domestic assets should not lead to correction of the current account deficit: there should not be declines in creditworthiness leading

\footnotetext{
${ }^{4}$ See, also, Xafa (2007).
} 
to a pullback for global investors, nor should the rising debt lead to spending restraint by U.S. residents as long as total wealth is rising.

Finally, the aggregate NIIP may be only loosely related to the credit risk that foreign investors face. In principle, the creditworthiness of a borrower is determined by, among other things, the total debt the borrower has issued. For most international borrowers in an industrial economy, however, foreigners represent only a small portion of their creditor base, with most liabilities being to domestic residents. Therefore, the fact that foreign claims on the United States are rising does not necessarily mean that U.S. indebtedness is rising relative to its ability to repay. The diversity and distribution of creditworthiness across borrowers in a given economy is likely to influence the credit risks faced by foreign investors to a greater degree than the overall foreign indebtedness of the economy. (As discussed in more detail in Section III.5, the riskiness of U.S. external debt is reduced by the fact that the major debtor is the U.S.

government.) This is reinforced by the fact that in most industrial countries, it is not possible to treat foreign creditors differently from domestic creditors.

\section{Simulations of the U.S. balance of payments}

With these qualifications in mind, we now consider projections of the U.S. balance of payments to determine whether the key criterion for current account sustainability-the stability of the NIIP/GDP ratio-is likely to be met. For this exercise, we use the Federal Reserve Board's partial-equilibrium model of the balance of payments, which is described briefly below. (A more complete description is provided at the end of this paper.)

Before proceeding, we address the desirability of using a partial equilibrium model— which assumes the key macroeconomic drivers of the current account to be exogenous - to assess current account sustainability. In principle, the new generation of forward-looking 
dynamic general equilibrium models might be better suited for longer run macroeconomic projections. However, in these models, trade deficits and external debt represent equilibrium responses to shocks, and asset prices and deficits start to correct long before economies reach any putative debt limits. (See, for example, Erceg, Guerrieri, and Gust, 2006) Conversely, much of the debate over U.S. external sustainability assumes that U.S. indebtedness may expand until it reaches certain limits, after which correction may be triggered. In this context, it makes sense to use a partial equilibrium model, which does not assume spending adjusts endogenously in response to future financing constraints, to forecast the paths of external imbalances and debt under plausible assumptions about output growth and prices, and then to assess whether those paths are sustainable. Moreover, the USIT partial-equilibrium model described below treats the U.S. balance of payments in considerably more detail than any general equilibrium model currently in use, and such detail is essential to assessing current account sustainability.

\section{III.1 The USIT model}

The USIT (U.S. International Transactions) model consists of 491 equations including 26 econometrically estimated behavioral equations, with the rest being identities and other computational equations. The model takes as exogenous projections for the central determinants of the U.S. external accounts, including: U.S. and foreign real GDP growth, U.S. and foreign inflation rates, U.S. interest rates, oil prices, and the foreign exchange value of the dollar. Based on these inputs, it then projects U.S. external balance variables in four broad categories: (1) trade flows, (2) non-trade components of the current account (especially investment income), (3) financing flows, and (4) the investment positions comprising the NIIP. Salient aspects of the modeling strategy and parameters are as follows: 


\section{(1) $\underline{\text { Trade sector }}$}

- Import prices for most major categories are projected based on the level of the dollar, foreign CPIs, and the U.S. CPI; the rate of passthrough from changes in the dollar to changes in merchandise import prices is quite low, about 1/3. Export prices depend on measures of U.S. production costs and final prices.

- Real imports for most major categories depend on both the prices of imports relative to U.S. prices-with an elasticity of about unity-and on U.S. GDP. Real exports for most major categories depend on the price of exports relative to exchange-rate-converted foreign CPIs-also with an elasticity of about unity-and on a trade-weighted aggregate of foreign GDPs. Importantly, these equations incorporate the Houthakker-Magee asymmetry in income elasticities: the elasticity of real imports with respect to U.S. GDP is about 1.75 on average, exceeding the elasticity of real exports with respect to foreign GDP, of about 1.25 on average. ${ }^{5}$

- Both the quantity and price of oil imports are modeled separately, with the former based on trends in U.S. production and consumption of oil, and the latter based on current and prospective market developments.

\section{(2) Non-trade components of the current account balance}

- Investment income is projected by applying income rates of return to different categories of U.S. external claims and liabilities.

- Assumptions on U.S. interest rates are used to project income rates on portfolio (equity, bond and deposit) positions. Skipping ahead slightly to Exhibit 2, the rates of income on U.S. private portfolio assets and liabilities have been roughly similar in recent years and are projected to remain so, at a level close to the projected U.S. short-term rate of interest, going forward. The income return on Government liabilities has been somewhat higher (closer to the long-term rate of interest) and is projected to remain somewhat higher than the private rates of return.

- The income rate of return on foreign direct investment in the United States depends on the U.S. output gap. The rate of return on U.S. direct investment abroad depends on the foreign output gap and the relative price of oil.

- Historically, income rates on U.S. direct investment abroad have exceeded that on foreign direct investment in the United States. Although this gap has narrowed over the past decade, it remains large and we project it to remain large in the future. ${ }^{6}$

\footnotetext{
${ }^{5}$ The theoretical basis for the Houthakker-Magee asymmetry remains ambiguous and the subject of controversy among trade modelers. Even so, the estimated coefficients in our trade models continue to exhibit the HouthakkerMagee asymmetry for goods trade. For services trade, in contrast, the income elasticity for exports exceeds that for imports. However, as goods trade exceeds services trade, the income elasticity for total imports exceeds that of total exports.

${ }^{6}$ A number of explanations have been advanced for the asymmetry of rates of return on direct investment, including
} 
- Transfers are projected exogenously, based on recent trends.

\section{(3) Financing Flows}

- Once the current account balance is projected, this pins down the amount of net financing flows into (out of) the U.S. economy. However, two additional facets of these flows must be specified. First, financial flows must be allocated among the various categories: direct investment and portfolio investment. Second, a given amount of net financing may be associated with any number of combinations of gross financing flows. For example, an $\$ 800$ billion net inflow may be achieved by $\$ 800$ billion in gross inflows from abroad, combined with 0 outflows; or it could be achieved by $\$ 1,600$ billion in gross inflows and $\$ 800$ billion in gross outflows.

- Gross direct investment flows to/from the United States depend on GDP growth in the recipient country.

- Foreign flows into U.S. government assets and U.S. government flows into foreign assets are projected at their recent trends.

- This leaves net private portfolio flows to balance the current account/financial account identity. The gross flows are constructed so as to produce growth rates in the stock of claims and liabilities that most closely match recent history while still having the implied net flows meet the net financing requirement. ${ }^{7}$

\section{(4) Investment positions}

- For each category of investment (direct investment, private portfolio, government portfolio, etc.), the gross asset or liabilities position in a given year will be equal to the position in the preceding year plus (a) financial flows (positive or negative) in that category during the year, and (b) valuation changes in the position.

- For all the simulation exercises, we report the direct investment positions and the NIIP using the current cost measure of direct investment. ${ }^{8}$

- In the simulation projections presented here, we include valuation changes to the direct investment positions alone, not the portfolio positions. The valuation changes for the

greater efficiency of U.S. firms, better project selection by U.S. firms, younger and thus less mature investments for foreign firms in the United States, greater competitive pressures in the U.S. market, or differences in tax treatment. (See Higgins, Klitgaard, and Tille, 2005.) None of these factors seem likely to disappear in the near term.

${ }^{7}$ This is accomplished by starting out with trend extrapolations of gross inflows and outflows. If more financing is needed, gross inflows are adjusted up and outflows are adjusted down symmetrically; the reverse occurs if less financing is needed.

${ }^{8}$ This is BEA's preferred measure as it avoids many methodological issues associated with estimating the stock market value of non-traded equity positions. In addition, for our simulations, using the current cost measure means our estimates do not depend on our assumptions about future stock market movements. 
direct investment positions reflect changes in exchange rates and in domestic prices of the assets (land, machinery, structures, etc.) comprising the position.

\section{III.2 Key assumptions for the projection}

The most important assumptions underlying the baseline balance-of-payments projection are shown on the first page of exhibit 2.

- The real multilateral exchange value of the dollar is held constant at its level at the beginning of 2008.

- For U.S. real GDP growth, rates in 2008 and 2009 are based on OECD projections, while longer-term growth rates of 2.4 percent are based on the OECD assessment of U.S. potential GDP growth in 2009 (OECD, 2008). In between the near term and farther out, growth jumps temporarily to restore the actual level of GDP to potential, after which growth subsides to its potential rate and the output gap remains at zero.

- GDP growth in the foreign industrial economies is projected in the same manner, based on OECD (2008). GDP growth in developing countries is based on the IMF's World Economic Outlook projections for 2008, on the average growth rate from 1997-2007 for further out, and also incorporates a transitional period to restore levels of GDP to their potential levels.

- For 2008 and 2009, U.S. long- and short-term interest rates are based on OECD (2008). Beyond a transitional period, long-term rates are set equal to the projected growth of nominal GDP: real growth of 2.4 percent plus inflation of 2 percent, based on the OECD 2009 projection. Short-term rates are set 1 percentage point below long-term rates.

- The price of imported oil is set flat at its value at the beginning of this year. Note that imported oil is comprised of a mix of different grades, and its price is accordingly lower than that of West Texas Intermediate, whose price approached $\$ 100$ per barrel around that time.

\section{III.3 Model projections}

The baseline projection

As indicated in the second page of Exhibit 2, after some initial wiggles, real exports grow at a pace of nearly 5 percent over most of the projection period. Real imports, reflecting their higher elasticity with respect to GDP, grow a touch faster than 5 percent. In consequence, the trade balance widens gradually as a share of GDP, reaching about 51/2 percent by 2020 . The nonoil trade deficit expands at a faster pace, as the volume of oil imports rises more slowly than 
other types of imports, consistent with trend declines in the oil-intensity of U.S. GDP. ${ }^{9}$ The current account balance also declines gradually as a share of GDP, reflecting not only the widening trade deficit, but also a (long-expected) shift in the balance on investment income from positive to negative as the NIIP gets more negative; net investment income and the current account deficit would deteriorate even faster were it not for the asymmetry in the rates of return on foreign direct investment. Finally, reflecting all of these developments, the NIIP/GDP ratio deteriorates steadily over the projection period, reaching over -60 percent of GDP by 2020 .

Because of their importance for net investment income and thus the current account balance, the third page of Exhibit 2 provides more detail on the composition of projected gross investment positions and on the rates of return on these positions. The bottom panel indicates that the high rates of return on direct investment claims that we are assuming is well in line with past history, while the rate of return on direct investment liabilities is, if anything, generous by historical standards. The similarity in our projection of rates of return on portfolio claims and liabilities is also supported by history. The top panel shows that increases in U.S. direct investment claims, which have the potential to significantly improve the net investment income balance owing to their high rate of return, do not appear out of line with the evolution of other categories.

We draw four central conclusions from this projection. First, based on the standard criterion-stability of the NIIP/GDP ratio-the U.S. current account balance is not sustainable in the long term. The NIIP/GDP ratio deteriorates by more than 40 percentage points of GDP by 2020 , or very roughly 4 percentage points per year. But, second, even if the current account is unsustainable, it is probably less unsustainable than would have been the case had we started the

\footnotetext{
${ }^{9}$ The saw-toothed pattern of the trade balance is caused by a residual seasonal pattern (even after seasonal adjustment by BEA) in oil imports.
} 
projection back in, say, 2000; at that time, as indicated in the first page of Exhibit 2, the real value of the dollar was considerably higher, and U.S. and foreign growth seemed more similar. Moreover, and third, it is doubtful that, by 2020 , the U.S. balance of payments will be entering any "danger zone" where external adjustment will be urgently required. Although the level of the net debt appears quite elevated (this will be discussed further below), net investment income payments still represent a paltry $1 / 2$ percentage point of GDP. This debt burden implies only a minimal drag on spending, nor would it wave a red flag to investors concerned about the creditworthiness of the U.S. economy. Fourth and finally, even if investors took more signal from the NIIP/GDP ratio than from the net investment income balance, it would take quite a few years before the net debt rose above 60 percent of GDP.

As in all forecasts, our projections depend crucially on the extrapolation of past relationships and parameters into the future. We would note that two of our most important such extrapolations have opposite effects on the outlook. On the one hand, our assumption that the Houthakker-Magee asymmetry in income elasticities will persist leads to forecasts of larger current account deficits and net debt than if we assumed this asymmetry to erode. ${ }^{10}$ On the other, our projection that the return on U.S. direct investment abroad will continue to exceed that on foreign direct investment in the United States leads to smaller deficits and debt than if the gap in rates of return were to start closing. All told, we are comfortable that these risks to our forecast offset each other to a reasonable extent, but we acknowledge that the outlook is quite uncertain.

\footnotetext{
${ }^{10}$ In fact, although our elasticities for individual trade components remain constant going forward, the income elasticity asymmetry for overall trade narrows in our projection. This is because the share of services in overall trade rises, and the income elasticity asymmetry for services trade (in contrast to goods trade) favors U.S. exports.
} 


\section{Comparison with other projections}

Compared with some previous exercises in projecting the U.S. balance of payments, our baseline projection pushes considerably farther into the future the date at which the U.S. external debt becomes a concern. For example, writing nearly a decade ago, Mann (1999) projected that with an unchanged exchange rate and standard growth assumptions, the U.S. current account deficit would reach 8 percent of GDP by 2010 and the NIIP/GDP ratio would reach -64 percent of GDP. With updated assumptions, Mann (2004) projected the current account deficit would reach roughly 13 percent of GDP by 2010. Cline (2005) projected that by 2010, the current account deficit would reach 71/4 percent of GDP and the NIIP/GDP ratio would reach 50 percent.

Comparing model simulations is difficult, but several factors likely contribute to the more benign outlook in our projections compared with Mann $(1999,2004)$ and Cline $(2005)$ : the dollar has fallen further from the levels assumed in their projections; a combination of valuation changes and data revisions have boosted the starting point for our projections of net investment income; and valuation changes and data revisions have boosted the starting point for our projections of the NIIP.

Two other projections might be mentioned, although they are more difficult to compare with ours. Higgins, Klitgaard, and Tille (2005) construct a scenario in which the NIIP/GDP reaches -65 percent of GDP in 2015 and -89 percent of GDP by 2025; this represents faster deterioration than in our projections, but it is based on the assumption that the current account deficit is fixed at 6 percent of GDP, a higher deficit than we project for most of the projection period. By contrast, Kitchen (2007) develops a projection in which the NIIP/GDP ratio reaches only -39 percent of GDP by 2015 — compared with about -50 percent of GDP in our baselinebut this projection assumes dollar depreciation of over 1 percent annually. Notably, Kitchen's analysis, like ours, assumes a persistent rate of return differential favoring U.S. direct investment 
abroad, and thus he also projects a very small deficit on net investment income, notwithstanding a still-substantial net external debt.

\section{Alternative projections}

We believe the baseline projection described above to be plausible, but certainly the confidence interval around future projections must be very large indeed. Accordingly, in this section we present several alternative projections to illustrate the range of uncertainty, shown in Exhibit 3.

In the first alternative projection, the rate of foreign GDP growth is increased by about $1 / 2$ percentage point, so that it grows about 4 percent annually. As shown by the magenta lines, the trade and current account deficits flatten out and then start narrowing; the net investment income balance is much improved, as higher foreign growth leads to more high-earning U.S. direct investment abroad; and the NIIP/GDP ratio deteriorates more slowly. Hence, with this relatively small alternation of assumptions, the present configuration of asset prices, growth rates, and exchange rates would likely be sustainable in the long term.

In the second alternative projection, the rate of foreign GDP growth is lowered by about $1 / 2$ percentage point and U.S. GDP growth is boosted about $1 / 2$ percentage point, so that they both grow at about 3 percent annually. As denoted by the green lines, under this scenario, the current account deficit widens to more than 8 percent of GDP by 2020, the NIIP/GDP ratio deteriorates beyond -70 percent, while the balance on net investment income now declines to about -1 percent of GDP. These outcomes are less sustainable than those in the baseline projection, but nevertheless, the debt-service ratio remains benign.

In the third alternative projection, shown by the red lines, oil prices rise at 5 percent annually. In this scenario, the trade deficit widens to nearly 8 percent and the NIIP/GDP ratio also deteriorates beyond 70 percent of GDP by 2020. But surprisingly, the balance on net 
investment income is nearly zero, much better than in the baseline. Higher oil prices boost the profits of U.S.-based oil companies, leading to higher receipts on direct investment abroad. All told, therefore, the higher oil prices have mixed implications for sustainability.

Finally, we consider a scenario - the blue lines — in which the dollar declines by 1 percent annually going forward and, as investors demand a higher return to compensate, U.S. interest rates rise by 1 percentage point as well. In this scenario, which might be regarded as quite gradual correction, the trade deficit is considerably reduced relative to baseline. This positive effect on external balance is partly offset by the higher payments required on U.S. portfolio liabilities, so that the net investment income deficit is larger than in the baseline. However, on balance the current account deficit is narrower than in the baseline projection and the NIIP/GDP ratio slightly less negative as well.

To sum up, the risks to our projection are both on the upside and the downside, and we believe the baseline represents a plausible modal scenario.

\section{Ex post historical simulation}

Obviously, beyond uncertainty about the exogenous variables in our simulations, another source of error in our projections is parameter uncertainty. To at least partially address this concern, Exhibit 4 presents the results of a simulation of the model starting in the fourth quarter of 1994 and ending in the fourth quarter of 2007. The exogenous variables are set to their actual historical values — denoted by the black lines — while the endogenous variables are simulated dynamically and shown in red.

The model does a surprisingly good job of tracking movements in the trade and current account balances. Simulated rates of return on direct and portfolio investment track history less well, but still follow the broad contours of the historical data, as does the predicted path of net investment income. The predicted ratio of the NIIP to GDP generally follows the actual path 
until 2003 or so, after which the predicted path continues to deteriorate while the actual NIIP/GDP ratio becomes less negative. However, much of the rise (to less negative values) of the actual NIIP/GDP ratio reflected revisions to the data which uncovered more U.S. assets abroad, and this could not be anticipated by the model.

All told, the ex post historical simulation provides some comfort that our model can give us useful insights into the outlook for the U.S. external balance.

\section{III.4 How negative a NIIP is worrisome?}

Theory tells us that a sustainable current account requires a stable NIIP/GDP ratio, and, accordingly, our baseline projection suggests that the U.S. current account is not sustainable in the long run. However, theory provides no guidance as to how large the negative NIIP/GDP ratio, or the ratio of net investment income payments to GDP, could become before triggering an adjustment that narrows the current account deficit. Accordingly, it is not clear whether the roughly -60 percent of GDP that the NIIP reaches in the baseline scenario is worrisome, or whether the current account deficit would be forced to adjust much before or much after it reached that point.

To address this question, we look at the experience of other industrial countries. The top panel of Exhibit 5 presents NIIP/GDP ratios for 19 industrial economies in 2006, the latest year for which these data are available for a broad array of countries. The exhibit makes clear that the current level of the NIIP/GDP ratio for the United States, about 20 percent, is well within normal bounds. More importantly, about five countries had negative NIIP/GDP ratios in the neighborhood of 60 percent or higher: New Zealand, Greece, Portugal, Australia, and Spain. Note that in baseline scenario on Exhibit 2, the U.S. NIIP does not reach 60 percent until 2019.

The bottom panel of Exhibit 5 presents data on the ratio of net investment income to GDP for a similar group of industrial economies. A couple of countries-Ireland and New 
Zealand-have negative net investment income balances of 5 percent of GDP or more, while several more have balances in the $-1 \frac{1}{2}$ to $-2 \frac{1}{2}$ percent range. Under the baseline scenario, the U.S. net investment income balance does not reach -1/2 percent of GDP until 2019.

In considering sustainability, the NIIP and net investment income are compared to GDP because GDP is a measure of a country's ability to service its debt. Exhibit 5a re-computes the data shown in Exhibit 5, presenting ratios of the NIIP and net investment income to an alternative measure of debt-repayment capacity, exports of goods and services. Because of the United States' relatively low share of exports in GDP, the country's negative NIIP/exports ratio in 2006 becomes somewhat larger relative to other countries, but remains smaller than that of the five countries (listed above) with negative NIIP/GDP ratios exceeding 60 percent. According to the baseline projection described above, the U.S. NIIP/exports ratio expands to -440 percent by 2020. This is a little larger than the $2006 \mathrm{debt} / \mathrm{export}$ ratios for the most highly indebted countries shown in Exhibit 5a. However, in the baseline projection, the U.S. negative net investment income balance as a share of exports remains smaller than 5 percent, which is considerably below many of the ratios shown on Exhibit 5a. Moreover, given that a country can reduce imports or expand exports as needed to repay external debt, we feel the NIIP/GDP and net investment income/GDP ratios shown in Exhibit 5 are probably better proxies for debtrepayment capacity.

Returning to those measures, Exhibit 6 plots the net investment income balances against net international investment positions. The scatterplot makes clear that, for the most part, economies with larger (more positive) NIIPs enjoy larger (more positive) net investment income balances. Because rates of return differ across countries, and across assets and liabilities as well, the linkage between NIIPs and net investment income balances is not perfect. This limited correlation is demonstrated most clearly by Ireland: Although its NIIP/GDP ratio is not 
unusually negative, its sizable direct investment liabilities pay a higher return than the debt instruments which constitute most of its assets. In consequence, it has an unusually large net investment income deficit. ${ }^{11}$

To get some sense of the limits of U.S. external indebtedness, a more relevant set of comparisons may involve international investment positions of economies at the time that they begin to experience current account adjustment. The top panel of Exhibit 7 presents the NIIP/GDP ratio at the onset of current account adjustment; the adjustment years are the same ones identified in research by Croke, Kamin, and Leduc (2006), and data are available for 15 of the 23 episodes identified. The chart makes clear that there is a very wide range of NIIP/GDP ratios associated with current account adjustment-in fact, a few countries even had positive NIIPs. Therefore, it is likely that many adjustments were triggered well before NIIPs reached some notional limit, and for reasons other than the NIIP per se. Even so, in three of the 15 episodes shown the NIIP/GDP ratios rose above 40 percent before adjustment occurred, roughly double the current U.S. level.

The bottom panel of Exhibit 7 presents analogous data on the ratio of net investment income to GDP during current account adjustment episodes. Again, a considerable dispersion of net investment balances is apparent. Moreover, in 9 of the 22 episodes, the negative net investment income ratio exceeded 3 percent, a level that, in our baseline projection, the United States does not come close to reaching in the next 12 years.

The possible limits to the NIIP and the net investment position thus appear to depend on country-specific factors. Exhibit 7a plots again the NIIP/GDP ratio and the investment income to GDP ratio at the year of current account adjustment (the solid bars) as well as the averages of

\footnotetext{
${ }^{11}$ Some may wonder why the United States, which is well known to have rates of return on external assets in excess of those on external liabilities, appears so unremarkable and close to the trend line in the scatterplot. The reason is simply that many of the industrial economies shown share this favorable rate-of-return asymmetry.
} 
these measures for these countries in years prior to adjustment (the shaded bars). This analysis indicates that for many countries, current account adjustment occurred when these ratios reached levels that were notably more negative than over their previous history. However, it is also clear from the lower panel that many countries had a history of net investment income payments averaging 2 percent or more of GDP without current account adjustment. In Section V, we will revisit the question of whether, historically, higher levels of net debt have been associated with higher likelihoods of subsequent external adjustment.

\section{III.5 Is the United States special?}

In this section, we showed that the U.S. current account balance remains unsustainable, in the sense that given plausible future paths for GDP growth, interest rates, and oil prices, as well as an unchanged path of the exchange rate, the NIIP/GDP ratio will likely become increasingly negative. However, a comparison with the experiences of other industrial countries suggests that, even as far away as 2020 , the U.S. net external debt will still be no larger than it is today for five industrial economies, and the servicing burden on that debt will be relatively minor. These considerations suggest that no adjustment will be required in the near term, at least as a consequence of international balance sheet considerations.

But how relevant is the experience of other industrial economies for the United States?

In fact, some arguments suggest that measures of external indebtedness could become even greater for the United States than for other industrial economies before adjustment was needed. An increasingly prevalent view holds that because the United States offers especially broad, deep, and liquid financial markets, along with strong investor protects, global investors find U.S. assets unusually attractive, accept lower rates of return on U.S. assets than those of other countries, and would be willing to finance the deficit for a long period (Clarida, 2005, Cooper, 2005, Hubbard, 2005, 2006, Gourinchas and Rey, 2007, Forbes, 2008). However, Curcuru, 
Dvorak, and Warnock (2008) cast doubt on the view that U.S. rates of return on its portfolio liabilities are significantly below those on its assets, and Gruber and Kamin (2008) also present evidence undermining the view that U.S. assets are special.

But even if U.S. assets in aggregate hold no special attraction for global investors, above and beyond their standard return and risk characteristics, a second consideration suggests that the U.S. may be able to expand its debt to an unusual extent. Among the different categories of U.S. debtors, a key international borrower is, of course, the federal government. At the end of 2007, foreign holdings of U.S. Treasuries and agency debt amount to about $\$ 3.8$ trillion, accounting for 22 percent of total U.S. foreign liabilities. ${ }^{12}$ Given the U.S. government's commitment to the quality of its debt and its access to effective taxation, this likely makes U.S. external debt, overall, more creditworthy than if it had been issued primarily by U.S. households. Equity and direct investment holdings made up an additional 29 percent of U.S. foreign liabilities. Such instruments involve no credit risk, and their valuation depends far more on the profitability of the U.S. capital stock than the extent to which that stock is owned by foreigners.

The composition of U.S. assets and liabilities may also help boost the sustainable size of the United States' net debt. As is often remarked, because the United States' foreign-currency denominated assets well exceed its foreign-currency denominated liabilities, a decline in the dollar tends to reduce the net debt. This makes U.S. debt-servicing less vulnerable to dollar depreciation, and hence probably raises the level of sustainable debt.

A number of other considerations, however, suggest that the United States may have a diminished scope to issue external debt compared with other countries. First, some of the highly indebted economies shown in Exhibit 5 may themselves represent special cases: Given their

\footnotetext{
${ }^{12}$ Foreign investors held an estimated 57 percent of long-term marketable Treasury debt outstanding and over 21 percent of U.S. government agency debt outstanding.
} 
abundant resources, it may be sensible for Australia and New Zealand to import substantial capital and repay slowly over a long time horizon. Similarly, the large deficits and debts of Portugal, Spain, and Greece may be an artifact of their integration into EU and the euro area.

Second, put simply, the United States is the largest economy in the world, and heavy issuance of liabilities could saturate global demand. This consideration is addressed in Section IV below.

\section{Measures of Investor Exposure to U.S. Assets}

The NIIP/GDP ratio is primarily a signal, albeit a highly imperfect one, of the weight of an economy's debt service obligations; when the NIIP/GDP ratio reaches a certain size, investors may decide to limit their acquisition of the economy's assets, fearing that larger NIIPs may not be serviceable. In addition to concerns about creditworthiness, however, investors may also seek to limit their exposure to an economy because that exposure threatens to breach a certain share of their portfolio. ${ }^{13}$ The NIIP/GDP ratio is not a very useful measure of this type of exposure, that is, of the weight of U.S. assets in foreign portfolios. In this section, we address several more direct measures of the exposure of investors to U.S. assets.

IV.1 Recent measures of foreigners'exposure to U.S. assets

Exhibit 8 plots the share of U.S. equities and bonds in the global market capitalization of those instruments. This measure draws no distinction between U.S. and foreign investors, and merely gauges whether persistent U.S. current account deficits have been associated with more rapid issuance of equity and bond liabilities than is occurring in other economies. In fact, the

\footnotetext{
13 Mann (1999, 2002, and 2003) and Cline (2005), among others, also draw a distinction between creditworthinessand exposure-based criteria for sustainability, and present calculations based on these concepts. Concerns about creditworthiness and exposure are not necessarily unrelated. In a portfolio balance model, investors allocate their wealth to different assets, based on expected returns and uncertainties about those returns. Therefore, the more creditworthy an asset is considered to be, the higher the share in wealth allocated to that asset.
} 
data show little net rise since the late 1990s in the U.S. share of global market capitalization for these instruments, likely reflecting two factors. First, financial deepening is progressing rapidly abroad, and increased securities issuance has led to ratios of market capitalization to GDP abroad that approach those of the United States. ${ }^{14}$ Second, declines in stock prices, on balance, since 2000 and declines in the dollar since 2002 have also kept exposures to U.S. assets in terms of the shares held in check.

An alternative approach to gauging the exposure of investors to U.S. assets is to measure the share of U.S. assets in foreign portfolios. Exhibit 9 compares, for the limited number of countries and years for which survey data are available, the change over time in (1) the aggregate share of holdings of U.S. equities and bonds in overall holdings by foreigners of these instruments (the blue bars), and (2) the aggregate share of overall holdings by foreigners of these instruments comprised of claims on residents outside their own countries (the red bars). ${ }^{15}$ Note that overall holdings include not only a country's cross-border holdings of equities or bonds, but also its holdings of its own domestic equities or bonds. A number of observations can be made. First, the share of U.S. equities and bonds in the aggregate portfolios of foreigners has not risen much since 1997, and most or all of that increase took place between 1997 and $2001 .^{16}$ Second,

\footnotetext{
${ }^{14}$ Balakrishnan, Bayoumi, and Tulin (2007) find that declining home bias and financial deepening account for most of the financing of the recent large U.S. current account deficits, rather than increases in the share of U.S. assets in foreign portfolios.

${ }^{15}$ Data on foreign holdings of U.S. and other external securities are derived from the IMF's Coordinated Portfolio Investment Surveys (CPIS). Because the CPIS captures non-reserve holdings only, we impute an amount for holdings of both U.S. and other external securities held as reserves using data from the IMF SEFER and COFER surveys. Most industrial countries and a number of emerging-market countries now participate in the CPIS. In terms of major holders of U.S. securities, they exclude investments held in some major custodial centers, by most Middle East oil exporters, and by China. Holdings of U.S. securities accounted for by CPIS countries in 2006 represent about 70 percent of total U.S. securities held by foreign investors. See Bertaut, Griever, and Tryon (2006) for a discussion of the methodology for imputing reserve holdings, and for a more complete discussion of the comparability between holdings of U.S. securities as measured by the CPIS and by U.S. liability surveys. Data on holdings of domestic securities are derived from national source financial balance sheet accounts where available, and otherwise from estimates of domestic equity and bond market capitalization.
}

${ }^{16}$ The 1997 and 2001 figures are not strictly comparable because more countries participated in the 2001 CPIS than in the 1997 CPIS. However, the difference in coverage is less critical for comparing relative shares than absolute 
compared to the share of U.S. assets in portfolios abroad, the share of all external (to them) assets in portfolios abroad has risen by as much or more. This relationship may be seen more easily in Exhibit 10, which indicates the share of U.S. equities and bonds in the external portfolios of foreigners. (In these calculations, holdings of a given country's domestic securities are subtracted from its overall holdings to arrive at its external holdings.) The shares of both U.S. equities and bonds in these portfolios rose between 1997 and 2001, but have declined or been little changed since 2001 .

Exhibit 11 assesses the extent to which foreigners are "underweight" in U.S. assets, and compares that to the extent that they are underweight in external assets more generally. ${ }^{17}$ Foreigners are considered to be appropriately weighted (in terms of a standard portfolio allocation model) in U.S. equities, for example, if the share of U.S. equities in their total equity portfolio-the blue bars in Exhibit 9-is equal to the share of U.S. equities outstanding in global equity capitalization-as shown in Exhibit 8. We thus compute foreigners' relative portfolio weights in U.S. assets (plotted against the vertical axis) by dividing the share of U.S. securities in the total portfolio of foreigners by the size of the U.S. market relative to the world market:

$$
\begin{gathered}
\text { Share in US securities }=\frac{\text { foreign holdings of US securities }}{\text { foreign holdings of all securities }} \\
\text { Weight in US securities }=\frac{\text { Sharein US securities }}{\text { US Market Cap }}
\end{gathered}
$$

holdings, and indeed the increase in shares held between the two years owes largely to the increases registered by countries that were participants in both years.

${ }^{17}$ See Bertaut and Griever (2004), for a fuller elaboration of this approach. 
A relative portfolio weight of 1 implies appropriate weighting of U.S. assets in foreigners' portfolios, while a relative weight less than 1 implies an underweighting of U.S. assets.

A similar calculation is undertaken for the foreigners' relative portfolio weight in all external securities, where for any given country outside the United States, "external" refers to all countries external to that country (including the United States). ${ }^{18}$ A value of this calculation (plotted against the horizontal axis) less than 1 implies that foreigners are underweight in assets outside their own country and overweight in domestic securities-that is, they exhibit home bias.

Observations on the dashed 45-degree line would indicate that foreigners are equally underweight U.S. and other external assets. The data indicate that foreign investors are both underweight in U.S. assets and in external assets more generally - that is, they exhibit home bias. In 1997, the bias against U.S. assets appeared to be considerably greater than the bias against other countries' assets. Since then, foreigners appear to have reduced their bias against U.S. and other countries' equities about equally. The same appears true for foreign holdings of U.S. and other external bonds between 2001 and 2006; between 1997 and 2001, they appear to have reduced their bias against U.S. bonds by somewhat more. Although foreigners' home bias has declined over this period, foreigners remain more underweight in U.S. securities than they do in external securities in general.

The bottom line from Exhibits 8 - 11 is that, in spite of the expansion of U.S. external liabilities since the mid-1990s, neither the shares nor the relative weights of U.S. assets in foreigners' portfolios have increased to any meaningful extent. This somewhat surprising result is, in part, a reflection of the decline in the dollar since 2002, which has reduced the value of

\footnotetext{
${ }^{18}$ In this analysis, we consider intra-euro area holdings of other euro-area country securities as domestic securities.
} 
holdings of dollar-denominated instruments relative to those denominated in other currencies. However, this result also reflects the increases of asset holdings abroad more generally, of which increased holdings of U.S. assets are just a part. All told, there is no evidence that an overhang of excessive foreign exposure to U.S. assets is developing which would require further adjustments in the U.S. current account balance or in U.S. asset prices to correct.

IV.2 Prospective future movements in foreigners' exposure to U.S. assets

Even if the exposure of foreigners to U.S. assets, relative to a number of benchmarks, does not appear to have increased much over the past decade, it is possible that the financing of continued current account deficits would push this exposure to more worrisome levels in the future. With the projected increase in the NIIP in our baseline projection described above, foreign investors will of necessity acquire many additional U.S. assets. How large a share of their portfolio foreign investors are willing to acquire is an open question. It depends importantly on factors beyond the evolution of the U.S. NIIP, including the growth of securities issuance in foreign economies and thus the share of U.S. securities in global market capitalization.

To devise an estimate of the potential magnitude of the effects of the projected increase in the NIIP on foreign portfolios, we perform the following exercise: We assume that both U.S. and foreign total market capitalization (reflecting equities and bonds combined) grow at their respective rates of nominal GDP, thus keeping their market cap/GDP ratios constant. As described in Section III, the USIT model simulations project gross portfolio flows into and out of the United States so that the resulting net financing is sufficient to meet the balance of payments requirements while also keeping the growth in the gross positions as close as possible to their 
recent historical rates. ${ }^{19}$ Thus, the total portfolio of foreign investors is projected to grow along with foreign market cap (minus the amount acquired by U.S. investors), plus estimated increased holdings of U.S. securities. Finally, we perform an alternative calculation in which the projections for financial flows into and out of the United States remain the same, but both U.S. and foreign market cap grow at the same rate (equal to the average of foreign and U.S. growth), so that U.S. market cap stays constant as a share of global market cap.

As illustrated in Exhibits 12A-12D, the results of this projection exercise generally point to increases in the share and relative weight of U.S. assets in foreigners' portfolios, but it is not clear those increases would be worrisome. Panel A shows projections for total U.S. market cap as a share of global market cap. (This panel is comparable to the share concept in Exhibit 8, but combines equity and bond capitalization.) Under the baseline assumption, total U.S. market cap declines to about 32 percent of global market cap by 2020, reflecting the slower projected growth of U.S. nominal GDP and thus of U.S. market cap, compared with foreign GDP and market cap. In the alternative simulation, the U.S. share of market cap stays constant, by design.

Panel B shows that if foreigners acquire U.S. assets sufficient to accommodate the rise in the NIIP, the share of U.S. market cap held by foreigners rises from around 20 percent currently to near 40 percent in either simulation.

Panel C shows the evolution of U.S. securities as a share of the total portfolio of foreigners (comparable to the blue bars in Exhibit 9) and panel D shows the corresponding evolution of the relative portfolio weights in U.S. securities (comparable to the relative portfolio weights in U.S. securities shown in Exhibit 11). Under either simulation, the share increases to

\footnotetext{
${ }^{19}$ Specifically, we assume that as foreigners acquire additional non-direct investment claims on the United States, the share of these claims that are securities (as opposed to bank deposits, trade credits, etc.) will mirror their current share in non-direct investment claims. Similarly, as U.S. residents acquire additional non-direct investment claims on foreigners, the share of these claims that are in the form of securities will mirror their current share.
} 
around 20 percent by 2020 , and the corresponding estimated relative weight of U.S. securities in foreigners' portfolios increases to $55-60$ percent. ${ }^{20}$ This increase in the relative weight is substantial, but even so, a relative weight of .55 implies that foreigners would remain underweight in U.S. assets. Moreover, although we cannot perform a similar projection of the relative weight of external securities in foreigners' portfolios, presumably that weight would also be rising substantially, assuming the trends documented in Exhibit 11 continue. ${ }^{21}$

\section{How Responsive are Asset Prices to International Balance Sheet Indicators?}

To make an assessment of how imminent is a correction in the current account balance, one must know the answers to three questions. First, what is the likely future evolution of the current account balance, debt service, and external debt ratios? We took a stab at answering this question with the simulations illustrated in Exhibits 2 - 4, and 12. Second, what are likely benchmarks for external debt indicators, beyond which external adjustment becomes more probably? We surveyed data on the external debt profiles of other industrial economies to make some tentative judgment as to upper range of reasonable levels of external indebtedness.

Third and finally, as external indebtedness rises, what is the probable effect of this rise on interest rates, exchange rates, and, ultimately, the current account balance? For example, once the negative NIIP/GDP ratio breaches some threshold of sustainability, how rapidly do investors

\footnotetext{
${ }^{20}$ The starting figures for 2006 -a 12 percent share of U.S. assets in total portfolios corresponding to a U.S. portfolio weight of about .28-are slightly larger than the shares and weights in exhibits 9-11 because for this exercise, we base total foreign holdings of U.S. securities on the more comprehensive liabilities estimates that underlie the NIIP calculations, and thus we are are able to include all foreign holdings of U.S. securities, including those held by countries not participating in the CPIS surveys, notably international financial centers, Middle East oil exporters, and China. Note also that the average shares and weights will more closely resemble the bond shares and weights in the exhibits because the majority of foreign holdings are in the form of U.S. bonds.

${ }^{21}$ We are not able to project how changes in foreigners' shares and weights held in total external securities compare with the projected changes in shares and weights held in U.S. securities. Although we are able to forecast total foreign (non-U.S.) market cap held by foreigner investors, we have no way of allocating what fraction of that foreign market cap reflects foreigner investors' home country securities and what fraction reflects holdings of other foreign securities.
} 
pull back from a country's assets, thus boosting interest rates, pushing down the currency, and inducing current account adjustment? As an initial rough cut at answering this question, we describe below regressions of interest rates and exchange rates on measures of international balance sheet positions, as well as a range of macroeconomic control variables. We also refer to econometric estimates by Gruber and Kamin (2008) of the effect of the NIIP/GDP ratio on current account balances.

\section{V.1 Long-term interest rates}

Were increases in external debt to lead to concerns about a country's creditworthiness and to a pullback by global investors, one should observe an increase in a country's domestic interest rates. To examine this possibility, we estimate panel regressions using annual data for 22 industrial countries over the period 1975 to $2006 .^{22}$ The dependent variable is the nominal longterm (usually 10-year) yield on government benchmark bonds. A set of control variables includes the overnight money market interest rate, the four-quarter rate of CPI inflation, the fourquarter rate of real GDP growth, the standard deviation of the quarterly change in the long-term nominal interest rate over the preceding 12 quarters, the ratio of the structural (full-employment) fiscal balance to GDP, and two annual lags of the dependent variable.

The first column of Table 1 presents the results of this equation, estimated including only the control variables. The results are, for the most part, consistent with expectations. Increases in money market interest rates, inflation, and real GDP growth all boost nominal long-term bond yields by a statistically significant extent. Also as one would expect, increases in the volatility of interest rates boost yields and increases in the fiscal balance reduce yields, although these effects are not statistically significant.

\footnotetext{
22 The specification is similar to that employed in Gruber and Kamin (2008), who, in turn, based their equation on that in Warnock and Warnock (2006).
} 
The next column of the table adds year and country fixed effects, as well as a dummy variable that becomes one in 1999, with the creation of the euro area. The coefficients on the control variables are, for the most part, little changed.

The next four columns add, separately, to this equation four different measures of external balance, all lagged one year: the NIIP/GDP ratio, the ratio of net investment income (NIINCOME) to GDP, the current account (CAB)/GDP ratio, and the share of a countries' gross external liabilities in the gross external assets of foreigners (Ext. Liab.). The remaining columns present results of equations that include all four of these external balance measures together, but with different combinations of year and country fixed effects.

By and large, there is little evidence that the external balance measures examined here are associated with a significant effect on long-term yields. To the extent that any of these variables has a consistent and nearly significant effect of the expected sign, it is the NIIP/GDP ratio. At its largest, the coefficient on this term is -.005, implying that a 100 percent of GDP negative NIIP would be associated with an increase in the long-term nominal interest rate of 50 basis points-this is a discernable, but not especially large, increment. The current U.S. NIIP of about 20 percent of GDP implies a boost to the interest rate of a fifth of that, of only 10 basis points. (This is a much smaller effect than estimated by Lane and Milesi-Ferretti, 2001, using a more limited set of control variables.)

In interpreting the coefficients on the external balance variables, a prominent identification problem should be acknowledged. In principle, countries with highly developed financial systems and strong investor protections should attract foreign investors. As noted earlier, a number of analysts suggest that the particular attractiveness of U.S. assets helps to explain the large U.S. current account deficits. (See, among others, Blanchard, Giavazzi, and Sa, 2005, Clarida, 2005, Cooper, 2005, Hubbard, 2005, 2006, and Forbes, 2008.) These large capital 
inflows, in turn, ought to lower U.S. long-term yields. Accordingly, a priori, it is not clear whether large external debts should be associated with higher interest rates, because they raise concerns among investors, or lower interest rates, because the large debts reflect strong investor interest.

However, the estimates shown in columns 2-6 and 9-10 should, to a large extent, control for the simultaneity problem described above, as they include country fixed effects. Any special attractiveness of a country's assets is likely to be persistent, to affect bond yields for extended periods, and thus to be picked up in the coefficient on the country effect. Some evidence in support of this view is provided by the fact that in columns 7 and 8 , where no country fixed effects are included, the coefficient on the NIIP/GDP ratio is much smaller than in columns 9 and 10, where country fixed effects have been included. This suggests that the country fixed effects are, indeed, helping to control for the simultaneity problem.

\section{V.2 Exchange rates}

Another sign that investors are pulling back from financing a country's current account deficit is, of course, a depreciation of the exchange rate. Therefore, if higher levels of external debt and debt-service are systematically associated with a higher probability of external adjustment, they should also be associated with subsequent exchange rate depreciations. To assess whether this is, indeed, the case, we re-estimated the panel equations shown in Table 1, but substituted measures of the real exchange rate in place of nominal long-term interest rates. We use the CPI-deflated multilateral exchange rate published in the IMF's International Financial Statistics. ${ }^{23}$ (An increase indicates appreciation.)

In Table 2, the dependent variable is the percent deviation of the real exchange rate from its country-specific sample mean. The coefficient on the money market interest rate is positive

\footnotetext{
${ }^{23}$ These regressions are estimated for the same 22 industrial countries over the sample 1978-2006.
} 
and significant, while that on the inflation rate is about the same magnitude but negative and significant; together, these results confirm our expectation that increases in the real interest rate should positively affect the real exchange rate. None of the other control variables have a significant coefficient of the expected sign-this is perhaps not surprising, as exchange rate models are notoriously hard to estimate. The measured effects of the external balance variables are a mixed bag as well. The NIIP and net investment income generally have a positive effect on the real exchange rate as expected, but the effect is inconsistent in terms of sign and significance. Higher current account balances lead to lower exchange rates and larger external liabilities lead to higher exchange rates, the opposite of what we'd expect.

Finally, Table 3 re-estimates these equations, with the dependent variable specified as the percent change in the real exchange rate from the previous year. Now, the current account balance appears to be positively associated with the real exchange rate, but the coefficients on the other variables remain insignificant or of the wrong sign. ${ }^{24}$

\section{V.3 Current account balances}

Should the external debt of a country become large enough so as to raise serious concerns about its creditworthiness, ultimately developments must ensue which would lead to reduction of the current account deficit. But is there any evidence that higher levels of external debt lead to subsequent current account adjustments? Table 4 reproduces econometric results from Gruber and Kamin (2008). They estimate a panel regression, using data for a wide range of industrial and developing countries over the period 1982-2006, to explain the ratio of the current account balance of GDP. The regression estimates shown include standard determinants of current

\footnotetext{
${ }^{24}$ Gagnon (1996) finds evidence that net foreign assets scaled by trade flows are significantly associated with real exchange rates for a panel ending in 1995. In a multi-country probit study of industrial economies, Wright and Gagnon (2006) find that larger current account deficits are significantly associated with sharp real currency depreciations, but the magnitude of the effect is quite small. Other variables do not exert significant, robust effects on the probability of a sharp real depreciation.
} 
account balances drawn from the literature, and, for the most part, coefficients are as expected: larger current account balances (e.g., surpluses) are associated with higher per capita income, higher fiscal balances, lower age dependency ratios, higher net exports of oil, and, in the last two columns, higher indexes of governance. (Better governance is presumed to attract investment and thus lower the current account balance.)

Notably, the coefficient on a country's net foreign assets (i.e., the NIIP), is positive and significant. ${ }^{25}$ This is the opposite result that would obtain if more negative NIIPs led to smaller current account deficits. It may be that higher levels of net foreign asset increase the current account balance by raising net investment income, or it may be that the NIIP captures persistent elements of the current account balance that are not captured by the other explanatory variables. In any event, however, the result suggests that, at least in historical experience, it is difficult to find a systematic relationship between levels of external indebtedness and patterns of current account adjustment. Moreover, the result shown in Table 4 is not specific to the research of Gruber and Kamin (2008); Chinn and Prasad (2003) and Chinn and Ito (2007), as well as Gruber and Kamin (2007), also estimate positive coefficients on the NIIP.

Notably, Lane and Milesi-Ferretti (2002) find that although the NIIP/GDP ratio is not correlated with the trade balance, an adjusted measure that takes into account growth rates of GDP and interest rates is, indeed, correlated negatively, consistent with some stabilizing effects of the NIIP. However, Lane and Milesi-Ferretti (2001) look at the error-correction properties of the NIIP and find deviations of the NIIP from equilibrium are closed only slowly.

\footnotetext{
${ }^{25}$ The data are averaged into periods of 4 or 5 years. The net foreign assets variable is measured as its value in the preceding period.
} 


\section{V.4 Summing up}

In this section, we examined the extent to which, historically, deteriorations of external balance positions have been associated with pullbacks by global investors, as indicated by higher interest rates, more depreciated exchange rates, or increases in current account balances. All told, we found that greater external debt was associated with only small increases in interest rates and mixed effects on exchange rates. Of course, modeling financial market prices is notoriously difficult, so it may not be surprising that we found little evidence of strong linkages among indebtedness, interest rates and exchange rates. By the same token, however, the direst predictions that continued large U.S. current account deficits will lead to financial crisis remain unsubstantiated.

Evidence on the effect of external debt on the current account balances was also mixed, with Gruber and Kamin (2008) and other studies finding that greater net debt is associated with larger current account deficits, but Lane and Milesi-Ferretti $(2001,2002)$ finding evidence of some, albeit slow, stabilizing effects of the NIIP. This suggests that even if increases in net debt eventually lead to current account correction, that effect may take time to materialize.

\section{Conclusion}

In this paper, we addressed three questions about the prospects for the large U.S. current account deficit. Is it sustainable in the long term? If not, how long will it take for measures of external debt and debt service to reach levels that could prompt some pullback by global investors? And if and when such levels are breached, how readily would asset prices respond and the current account start to narrow?

To address these questions, we started with projections of a detailed partial-equilibrium model of the U.S. balance of payments. Assuming plausible settings of macroeconomic 
indicators in the United States and abroad, as well as a flat real dollar, our projections indicate that the current account deficit will resume widening and the negative NIIP/GDP ratio will continue to expand. This suggests that the configuration of macroeconomic settings underlying the current account balance at present is not sustainable in the long term. Nevertheless, compared with earlier years when the dollar was much higher, the current account balance is likely somewhat less unsustainable at present.

Moreover, compared with other industrial economies, current levels of the U.S. debt and debt service are relatively modest, and foreign exposure to U.S. assets has been moving down rather than up. Our projections suggest that even by the year 2020, the negative NIIP/GDP ratio will be no higher than it is in five industrial economies today, and U.S. net investment income payments will remain below 1 percent of GDP. Absent changes in the dollar and consequent valuation adjustments, the share of U.S. claims in foreigners' portfolios will likely rise over the next decade, but not to an obviously worrisome extent. All told, it seems likely it would take more than a decade for U.S. indebtedness to reach any limits of global investors' willingness to extend financing.

Finally, we explored the historical responsiveness of asset prices and the current account in a wide range of industrial economies to increases in different measures of net indebtedness and external imbalances. We discerned only a very small effect of external indebtedness on interest rates, and no clear and concerted effects on exchange rates. Similarly, increases in net external indebtedness appear to have exerted no systematic effect on subsequent levels of the current account balance. Accordingly, it is not clear that, even were the U.S. net debt to approach limits to its sustainability, the developments needed to correct the current accountchanges in growth rates, assets prices, exchange rates, and the like —-would materialize all that rapidly. 
We would emphasize that these findings do not imply that U.S. current account adjustment is necessarily many years away. Many factors could trigger such adjustment, including, inter alia, a surge in foreign growth, declines in U.S. growth, or intensified concerns about U.S. current account sustainability. In fact, judging by the developments of the last several years, we may already be in the middle of an adjustment episode. Our point is rather that international balance sheet considerations likely are not sufficient, by themselves, to require external adjustment any time soon. 


\section{References}

Balakrishnan, Ravi, Tamin Bayoumi, and Volodymyr Tulin (2007), "Globalization, Gluts, Innovation, or Irrationality: What Explains the Easy Financing of the U.S. Current Account Deficit," IMF Working Paper WP/07/160.

Bertaut, Carol and William Griever (2004), "Recent Developments in Cross-Border Investment in Securities," Board of Governors of the Federal Reserve System, Federal Reserve Bulletin, Winter.

Bertaut, Carol, William Griever, and Ralph Tryon(2006), "Understanding U.S. Cross-Border Securities Data," Board of Governors of the Federal Reserve System, Federal Reserve Bulletin, May.

Blanchard, O., Giavazzi, F., and Sa, F. (2005), “The U.S. current account and the dollar," NBER Working Paper No. 11137.

Chinn, M.D. and Ito, H. (2007), "Current account balances, financial development, and institutions: assaying the world 'savings glut'," Journal of International Money and Finance 26, 546-569.

Chinn, M.D. and Prasad, E.S. (2003), "Medium-term determinants of current accounts in industrial and developing countries: an empirical exploration," Journal of International Economics 59, 47-76.

Clarida, Richard H. (2005), "Japan, China, and the U.S. Current Account Deficit," Cato Journal 25, 111-114.

Cline, William R. (2005), The United States as a Debtor Nation, Institute for International Economics, Washington, D.C.

Cooper, R.N. (2005), “Living with Global Imbalances: A Contrarian View,” Institute for International Economics Policy Brief PB05-3, November.

Croke, Hilary, Steven Kamin, and Sylvain Leduc (2006), "An Assessment of the Disorderly Adjustment Hypothesis for Industrial Economies," International Finance, vol. 9, No. 1, pp. 3761 .

Curcuru, Stephanie, Tomas Dvorak, and Francis Warnock (2008), The Stability of Large External Imbalances: The Role of Returns Differentials," Quarterly Journal of Economics, forthcoming.

Debelle, Guy and Gabriele Galati (2005), "Current Account Adjustment and Capital Flows,” BIS Working Paper 169.

Edwards, Sebastian (2005), "Is the U.S. Current Account Deficit Sustainable? If Not, How Costly Is Adjustment Likely to Be?," Brookings Papers on Economic Activity, 1:2005, pp. 211228.

Eichengreen, Barry (2004), "Why the Dollar's Fall is Not to be Welcomed," Financial Times, December 20.

Erceg, Christopher, Luca Guerrieri, and Christopher Gust (2006), "SIGMA: A New Open Economy Model for Policy Analysis," International Journal of Central Banking, vol. 2, March, pp. 1-50. 
Forbes, Kristin (2008), "Why Do Foreigners Invest in the United States?" NBER Working Paper No. 13908, April.

Freund, Caroline (2005), "Current Account Adjustment in Industrial Countries," Journal of International Money and Finance.

Gagnon, Joseph E. (1996), "Net Foreign Assets and Equilibrium Exchange Rates: Panel Evidence," Board of Governors of the Federal Reserve System, International Finance Discussion Papers No. 574.

(2005), "Currency Crashes and Bond Yields in Industrial Countries," Board of Governors of the Federal Reserve System, International Finance Discussion Papers No. 837, August.

Gourinchas, Pierre-Olivier, and Helene Rey (2007), "From World Banker to World Venture Capitalist: US External Adjustment and the Exorbitat Priviledge," in Richard Clarida, ed., G7 Current Account Imbalances: Sustainability and Adjustment. University of Chicago Press, pp. 11-66.

Gruber, J.W., Kamin, S.B. (2007), "Explaining the Global Pattern of Current Account Imbalances," Journal of International Money and Finance 26, 500-522.

Gruber, Joseph and Steven Kamin (2008), "Do Differences in Financial Development Explain the Global Pattern of Current Account Imbalances?" Board of Governors of the Federal Reserve System, International Finance Discussion Papers No. 923, March.

Higgins, Mathew, Thomas Klitgaard, and Cedric Tille (2005), "The Income Implications of Rising International Liabilities," Federal Reserve Bank of New York, Current Issues in Economics and Finance, December.

Hubbard, R.G. (2005), “A Paradox of Interest,” Wall Street Journal, June 23.

Hubbard, R.G. (2006), “The U.S. current account deficit and public policy," Journal of Policy Modeling 28, 665-671.

Kitchen, John (2007), "Sharecroppers or Shrewd Capitalists? Projections of the US Current Account, International Income Flows, and Net International Debt," Review of International Economics, vol. 15, no. 5.

Lane, Philip R. and Gian Maria Milesi-Ferretti (2001), "Long-Term Capital Movements," IMF Working Paper WP/01/107, August.

Lane, Philip R. and Gian Maria Milesi-Ferretti (2002), "External Wealth, the Trade Balance, and the Real Exchange Rate," European Economic Review 46, pp. 1049-1071.

Mann, Catherine (1999), Is the U.S. Trade Deficit Sustainable? Institute for International Economics, Washington, D.C.

(2002), "Perspectives on the U.S. Current Account Deficit and Sustainability," Journal of Economic Perspectives, Vol. 16, No. 3, Summer, pp. 131-152.

(2003), "How Long the Strong Dollar?" in C. Fred Bergsten and John Williamson, eds., Dollar Overvaluation and the World Economy, Institute for International Economics, Washington, D.C. 
(2004), "Managing Exchange Rates: Achievement of Global Re-balancing or Evidence of Global Co-dependency," Business Economics, July.

Mussa, Michael (2004), "Exchange Rate Adjustments Needed to Reduce Global Payments Imbalances," in C. Fred Bergsten and John Williamson, eds., Dollar Adjusment: How Far? Against Whom?, Institute for International Economics, Washington, D.C., 113-138.

Mussa, Michael (2005), "Sustaining Global Growth while Reducing External Imbalances," in C. Fred Bergsten, ed., The United States and the World Economy, Institute for International Economics, Washington, D.C.

Obstfeld, Maurice and Kenneth Rogoff (2004), "The Unsustainable US Current Account Position Revisited," NBER Working Paper 10869.

Roubini, Nouriel and Brad Setser (2004), "The US as a Net Debtor: The Sustainability of US External Imbalances," manuscript.

Truman, Edwin (2004), "Budget and External Deficits: Same Family But Not Twins," prepared for the Federal Reserve Bank of Boston Annual Research Conference, June.

Warnock, Francis E. and Veronica Cacdac Warnock (2006), "International Capital Flows and U.S. Interest Rates," NBER Working Paper 12560, October.

Wright, Jonathan H. and Joseph E. Gagnon (2006), "Predicting Sharp Depreciations in Industrial Country Exchange Rates," Board of Governors of the Federal Reserve System, International Finance Discussion Papers No. 881, November.

Xafa, Miranda (2007), "Global Imbalances and Financial Stability," International Monetary Fund Working Paper WP/07/11, May. 


\section{Key Equations in the U.S. International Transactions (USIT) Model}

\section{TRADE IN GOODS AND SERVICES}

1. Core export volume:

$$
X_{\text {core }} / P_{\text {Xcore }}=f\left(Y_{f},\left(P_{\text {Xcore }} / E_{f / \$} \cdot P_{f c p i}\right)_{\text {Lag } 11}\right)
$$

2. Core import volume:

$$
M_{\text {core }} / P_{\text {Mcore }}=f\left(Y_{\text {Lag } 1},\left(P_{\text {Mcore }} / P_{\text {gdp }}\right)_{\text {Lag } 7}\right)
$$

3. Oil import volume:

$$
M_{\text {oil }} / P_{\text {Moil }}=C_{\text {oil }}+\Delta I_{\text {oil }}+X_{\text {oil }}-Q_{\text {oil }}
$$

(Exogenous for this study)

$$
C_{o i l}=f\left(Y,\left(P_{o i l} / P_{g d p}\right)_{\text {Lag } 80}, H D D, P_{n g} / P_{o i l}\right)
$$

4. Core export price:

$$
P_{\text {Xcore }}=f(P D)
$$

5. Core import price:

$$
P_{\text {Mcore }}=f\left(\left(P_{f}\right)_{\text {Lag } 1},\left(E_{f / \$}\right)_{\text {Lag } 1}, P C_{\text {Lag } 3}\right)
$$

6. Primary commodity price:

$$
P C=f\left(Y_{\text {world }},\left(P_{c p i} / P_{f c p i} / E_{f / \$}\right)_{\text {Lag } 7}, T\right)
$$

7. Services receipts:

$$
X_{\text {serv }} / P_{X s e r v}=f\left(Y_{f},\left(P_{X s e r v} / E_{f / \$} \cdot P_{f c p i}\right)_{\text {Lag } 7}\right)
$$

8. Services payments:

$$
M_{\text {serv }} / P_{\text {Mserv }}=f\left(Y,\left(P_{\text {Mserv }} / P_{g d p}\right)_{\text {Lag } 3}\right)
$$

9. Services receipts price:

$$
P_{\text {Xerv }}=f\left(P_{\text {serv }},\left(P_{f c p i} / E_{f / \$}\right)_{\text {Lag } 1}, P_{\text {Moil }}\right)
$$

10. Services payments price:

$$
P_{\text {Mserv }}=f\left(P_{f c p i} / E_{f / \$}, P_{g d p}\right)
$$

Note: exports and imports of computers and semiconductors are exogenous for both volumes and prices $\left(X_{\text {comp }}, X_{\text {semi }}, M_{\text {comp }}, M_{\text {semi }}, P_{X c o m p}, P_{X s e m i}, P_{\text {Mcomp }}, P_{\text {Msemi }}\right)$. Import, volume and price of natural gas are also exogenous.

11. Exports:

12. Imports:

13. Trade balance:

$$
X=X_{\text {core }}+X_{\text {comp }}+X_{\text {semi }}+X_{\text {serv }}
$$

$$
M=M_{\text {core }}+M_{\text {oil }}+M_{\text {comp }}+M_{\text {semi }}+M_{\text {serv }}+M_{n g}
$$

$T B=X-M$ 
14. Direct investment income receipts:

15. Direct investment income payments:

16. Portfolio investment income receipts: ${ }^{\dagger}$

(Private and government modeled separately)

17. Portfolio investment income payments: ${ }^{\dagger}$

(Private and government modeled separately)

18. Net investment income:

\section{CURRENT ACCOUNT}

18. Current account balance:

\section{FINANACIAL FLOWS}

19. Direct investment outflows:

20. Direct investment inflows:

21. Portfolio investment outflows: ${ }^{\dagger}$

22. Portfolio investment inflows: ${ }^{\dagger}$

23. Financial Account Balance:

24. Balance of payments identity:

$$
\begin{aligned}
& R_{d i}=f\left(Y G A P_{f}, P_{\text {Moil }} / P_{g d p}, \Delta E_{f / \$}\right) \\
& X_{d i}=R_{d i} \cdot\left(A_{d i}\right)_{\text {Lag } 1} \\
& R_{f d i}=f(Y G A P) \\
& M_{d i}=R_{f d i} \cdot\left(A_{f d i}\right)_{\text {Lag } 1} \\
& R_{\text {port }}=f\left(R_{\text {tbill }}, R_{\text {tbond } 10},\left(R_{\text {port }}\right)_{\text {lag } 1}\right) \\
& X_{\text {port }}=R_{\text {port }} \cdot\left(A_{\text {port }}\right)_{\text {Lag } 1}
\end{aligned}
$$

$$
R_{\text {fport }}=f\left(R_{\text {tbill }}, R_{\text {tbond } 10},\left(R_{\text {fport }}\right)_{\text {lag } 1}\right)
$$$$
M_{\text {port }}=R_{\text {fport }} \cdot\left(A_{f \text { port }}\right)_{\text {Lag } 1}
$$

$N I I=X_{d i}+X_{p o r t}-M_{d i}-M_{p o r t}$

$$
F C_{d i}=f\left(\Delta Y_{f}, P_{f c p i} / E_{f / \$},\left(A_{d i}\right)_{L a g 1}\right)
$$

$$
F L_{d i}=f\left(\Delta Y, P_{c p i},\left(A_{f d i}\right)_{L a g 1}\right)
$$

$F C_{\text {port }}=f\left(C A B, F A B, S D, K A B\left(A_{\text {port }}\right)_{\text {Lag } 1}, T\right)$

$$
F L_{\text {port }}=f\left(C A B, F A B, S D, K A B,\left(A_{\text {fport }}\right)_{\text {Lag } 1}, T\right)
$$

$F A B=F C_{d i}+F C_{\text {port }}-F L_{d i}-F L_{\text {port }}+F N_{\text {deriv }}$

VALUATION ADJUSTMENTS (with DI at current cost)

25. On Direct Investment Claims:

$$
V A_{d i}=f\left(\left(A_{d i}\right)_{l a g 1}, \Delta E_{f / \$}, \Delta P_{f c p i}\right)
$$

26. On Direct Investment Liabilities:

$$
V A_{f d i}=f\left(\left(A_{f d i}\right)_{l a g 1}, \Delta P_{n r i d}\right)
$$




\section{INVESTMENT POSITIONS}

27. Direct Investment Claims:

28. Direct Investment Liabilities:

29. Portfolio Claims: ${ }^{\dagger}$

30. Portfolio Liabilities: ${ }^{\dagger}$

31. Net International Investment Position:

$$
A_{d i}=\left(A_{d i}\right)_{l a g 1}+F C_{d i}+V A_{d i}+V A O_{d i}
$$

$$
A_{f d i}=\left(A_{f d i}\right)_{l a g 1}+F L_{d i}+V A_{f d i}+V A O_{f d i}
$$$$
A_{\text {port }}=\left(A_{\text {port }}\right)_{\text {lag } 1}+F C_{\text {port }}+V A_{\text {port }}
$$$$
A_{\text {fport }}=\left(A_{f p o r t}\right)_{\text {lag } 1}+F L_{\text {port }}+V A_{\text {fport }}
$$

$$
N I I P=A_{d i}+A_{\text {port }}-A_{\text {fdi }}-A_{\text {fport }}
$$

${ }^{\dagger}$ Private portfolio claims on foreigners and U.S. government claims on foreigners are modeled separately. For portfolio liabilities, foreign claims on the U.S. private sector are modeled separately from claims on the U.S. government.

\section{DEFINITION OF VARIABLES}

$\begin{array}{ll}\mathrm{A}_{\text {port }} & \text { Stock of U.S. portfolio assets abroad } \\ \mathrm{CAB} & \text { Current account balance } \\ \mathrm{C}_{\text {oil }} & \text { Oil consumption } \\ \mathrm{E}_{\mathrm{f} / \mathrm{S}} & \text { Nominal exchange rate (foreign currency per U.S. dollar) } \\ \mathrm{FC}_{\mathrm{di}} & \text { Direct investment outflows } \\ \mathrm{FL}_{\mathrm{di}} & \text { Direct investment inflows } \\ \mathrm{FC}_{\text {port }} & \text { Portfolio claims flows } \\ \mathrm{FL}_{\text {port }} & \text { Portfolio liabilities flows } \\ \mathrm{FN}_{\text {deriv }} & \text { Net derivatives flows } \\ \mathrm{NII} & \text { Net investment income } \\ \mathrm{I}_{\text {oil }} & \text { Inventories of oil } \\ \mathrm{M} & \text { Imports of goods and services } \\ \mathrm{M}_{\text {comp }} & \text { Imports of computers } \\ \mathrm{M}_{\text {core }} & \text { Imports of core goods (non-oil goods excluding computers and semiconductors) } \\ \mathrm{M}_{\mathrm{di}} & \text { Direct investment income payments } \\ \mathrm{M}_{\text {ng }} & \text { Imports of natural gas } \\ \mathrm{M}_{\text {oil }} & \text { Imports of oil } \\ \mathrm{M}_{\text {port }} & \text { Portfolio investment income payments } \\ \mathrm{M}_{\text {semi }} & \text { Imports of semiconductors } \\ \mathrm{M}_{\text {serv }} & \text { Imports of services } \\ \mathrm{NT} & \text { Net unilateral transfers and other income paid to foreigners } \\ \mathrm{PC} & \text { Non-fuel primary commodity prices } \\ \mathrm{P}_{\text {cpi }} & \text { CPI price index } \\ \mathrm{PD} & \text { Export weighted aggregate of various domestic goods prices } \\ \mathrm{P}_{\text {fcpi }} & \text { Foreign CPI } \\ \mathrm{P}_{\text {gdp }} & \text { GDP implicit price deflator } \\ \mathrm{P}_{\text {Mcomp }} & \text { Import price of computers } \\ \mathrm{P}_{\text {Mcore }} & \text { Import price of core goods } \\ \mathrm{P}_{\text {Moil }} & \text { Import price of oil } \\ \mathrm{P}_{\text {Msemi }} & \text { Import price of semiconductors } \\ \mathrm{P}_{\text {Mserv }} & \text { Import price of services } \\ \mathrm{P}_{\text {ng }} & \text { Price of natural gas } \\ & \\ & \end{array}$




\begin{tabular}{|c|c|}
\hline $\mathrm{P}_{\text {nrid }}$ & Nonresidential investment deflator \\
\hline $\mathrm{P}_{\text {oil }}$ & PPI price of oil \\
\hline$P_{\text {serv }}$ & PCE price of services \\
\hline $\mathrm{P}_{\mathrm{Xcomp}}$ & Export price of computers \\
\hline $\mathrm{P}_{\text {Xcore }}$ & Export price of core goods \\
\hline $\mathrm{P}_{\text {Xsemi }}$ & Export price of semiconductors \\
\hline $\mathrm{P}_{\text {Xserv }}$ & Export price of services \\
\hline$Q_{\text {oil }}$ & Domestic oil production \\
\hline $\mathrm{R}_{\mathrm{di}}$ & Rate of return on U.S. direct investment assets abroad \\
\hline $\mathrm{R}_{\mathrm{fdi}}$ & Rate of return on foreign direct assets in the United States \\
\hline $\mathrm{R}_{\text {fport }}$ & Rate of return on foreign portfolio assets in the United States \\
\hline $\mathrm{R}_{\text {port }}$ & Rate of return on U.S. portfolio assets abroad \\
\hline $\mathrm{R}_{\mathrm{tbill}}$ & U.S. 30-day T-bill interest rate \\
\hline $\mathrm{R}_{\text {tbond10 }}$ & U.S. 10 year T-bond interest rate \\
\hline $\mathrm{SD}$ & Statistical discrepancy in the U.S. balance of payments \\
\hline $\mathrm{T}$ & Time trend \\
\hline TB & Trade balance in goods and services \\
\hline TR & Index of U.S. tariff rates \\
\hline $\mathrm{VA}_{\mathrm{di}}$ & Price and exchange rate valuation adjustment for DI claims \\
\hline $\mathrm{VA}_{\mathrm{fdi}}$ & Price valuation adjustment for DI liabilities \\
\hline $\mathrm{VAO}_{\mathrm{di}}$ & Other valuation adjustments for DI claims \\
\hline $\mathrm{VAO}_{\text {fdi }}$ & Other valuation adjustments for DI liabilities \\
\hline $\mathrm{VA}_{\text {port }}$ & Total valuation adjustment for portfolio claims \\
\hline $\mathrm{VA}_{\text {fport }}$ & Total valuation adjustment for portfolio liabilities \\
\hline $\mathrm{X}$ & Exports of goods and services \\
\hline $\mathrm{X}_{\text {comp }}$ & Exports of computers \\
\hline $\mathrm{X}_{\text {core }}$ & Exports of core goods (goods excluding computers and semiconductors) \\
\hline$X_{\mathrm{di}}$ & Direct investment income receipts \\
\hline $\mathrm{X}_{\mathrm{oil}}$ & Exports of oil \\
\hline$X_{\text {port }}$ & Portfolio investment income receipts \\
\hline $\mathrm{X}_{\text {semi }}$ & Exports of semiconductors \\
\hline$X_{\text {serv }}$ & Exports of services \\
\hline Y & Real GDP \\
\hline $\mathrm{Y}_{\mathrm{f}}$ & Foreign real GDP \\
\hline YGAP & Output gap \\
\hline $\mathrm{YGAP}_{\mathrm{f}}$ & Foreign output gap \\
\hline$Y_{\text {world }}$ & \\
\hline
\end{tabular}


Finland's NIIP and Nokia Price

U.S. Dollars Per Share
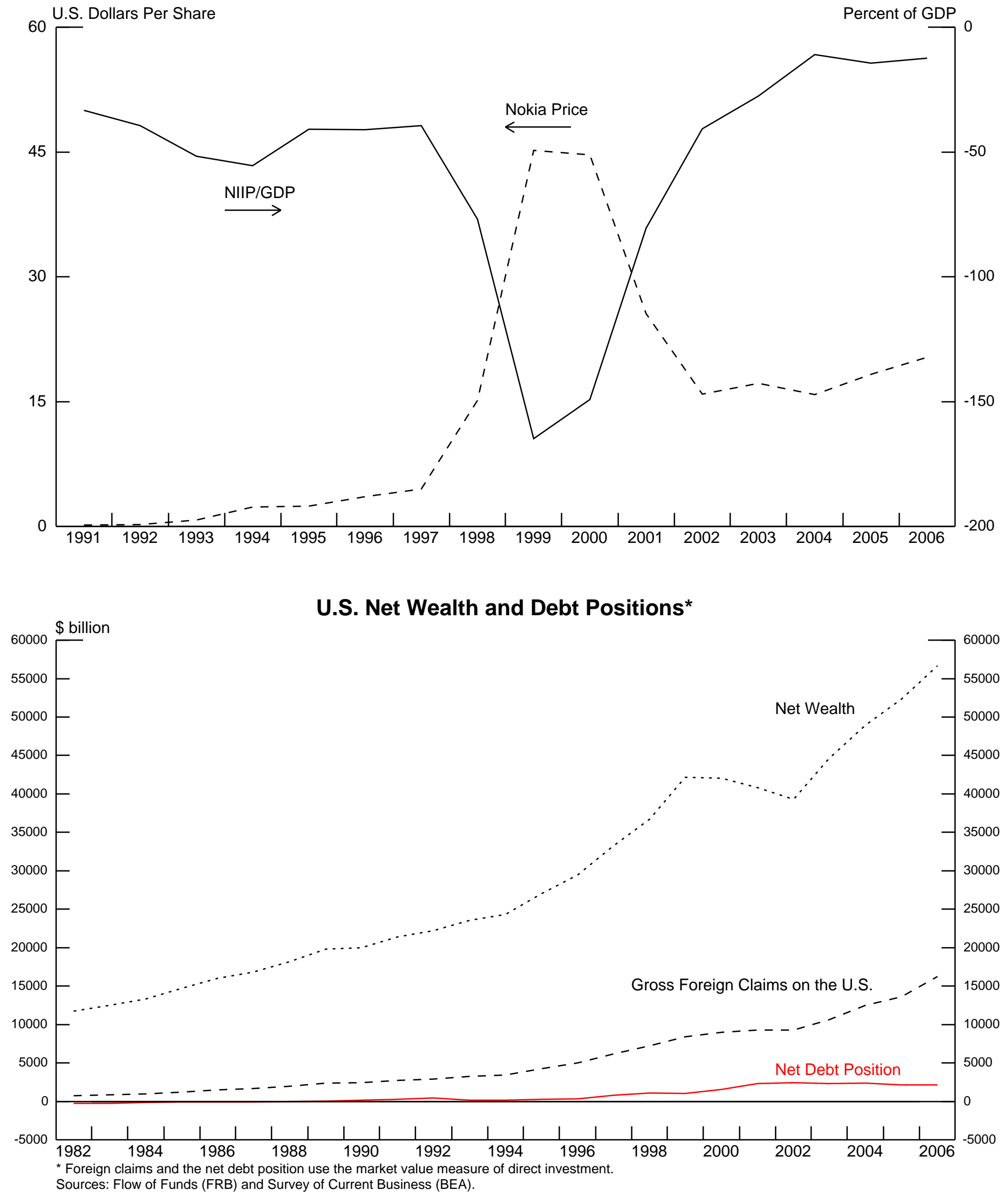


\section{Extended Baseline Projection}

\section{Real Exchange Rate}

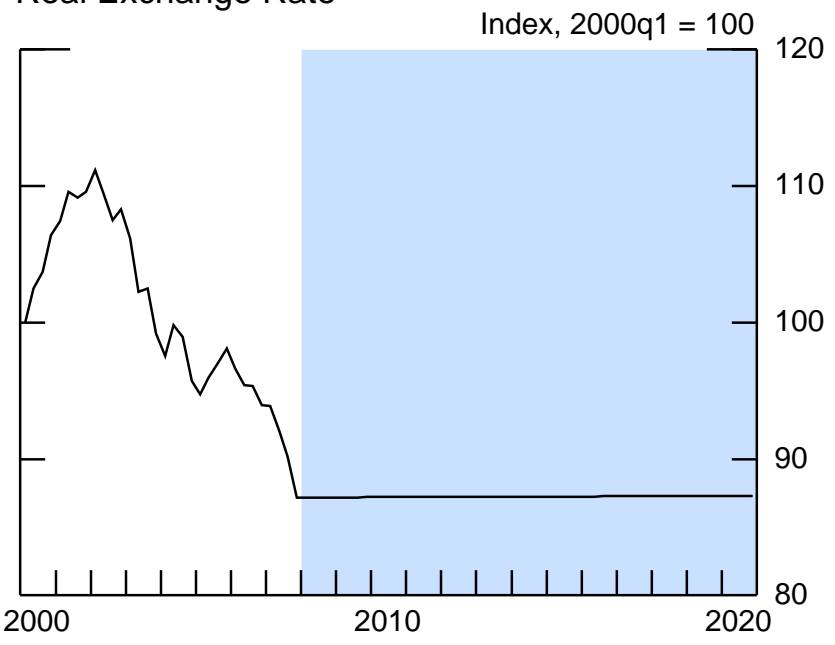

Oil Import Price

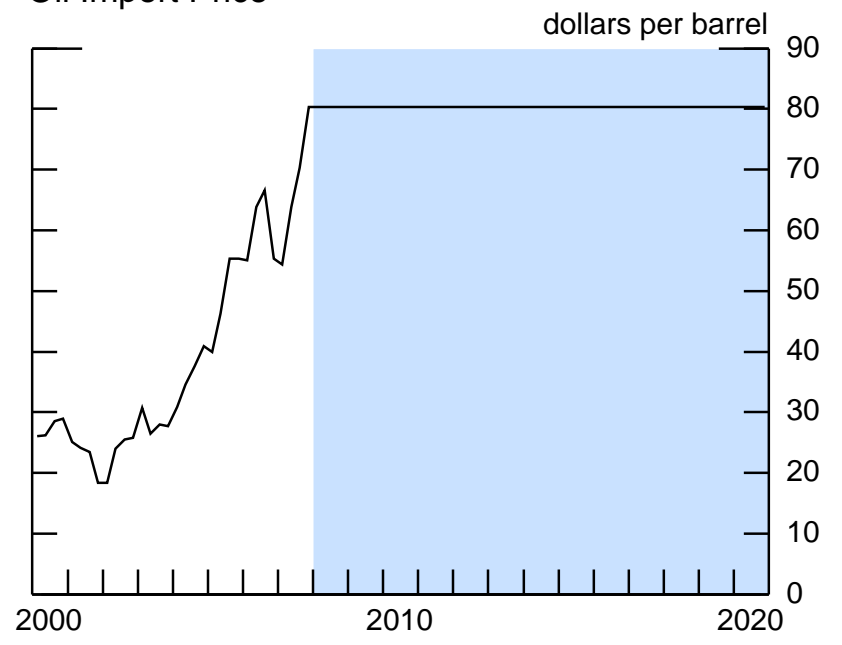

Rate of Return on Portfolio Investment

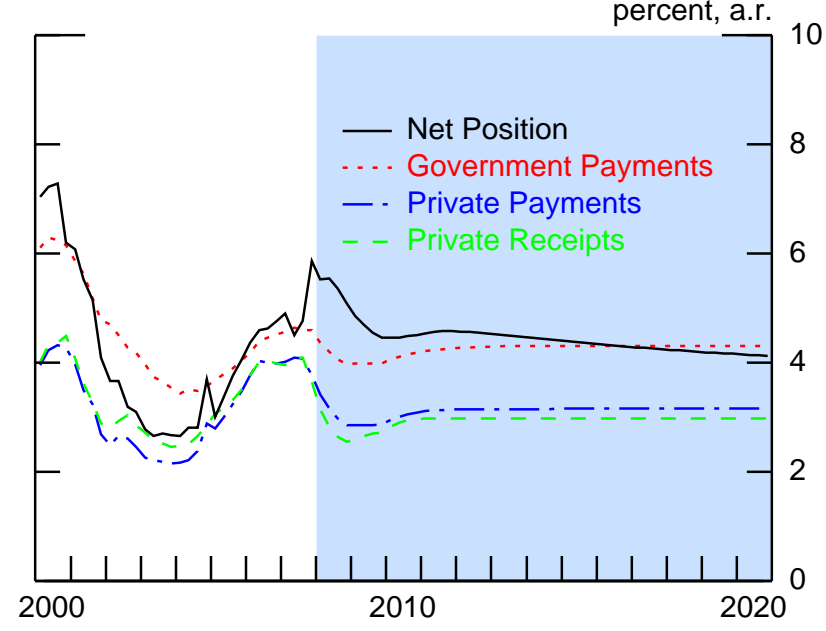

Foreign GDP (with US GDP, dashed)

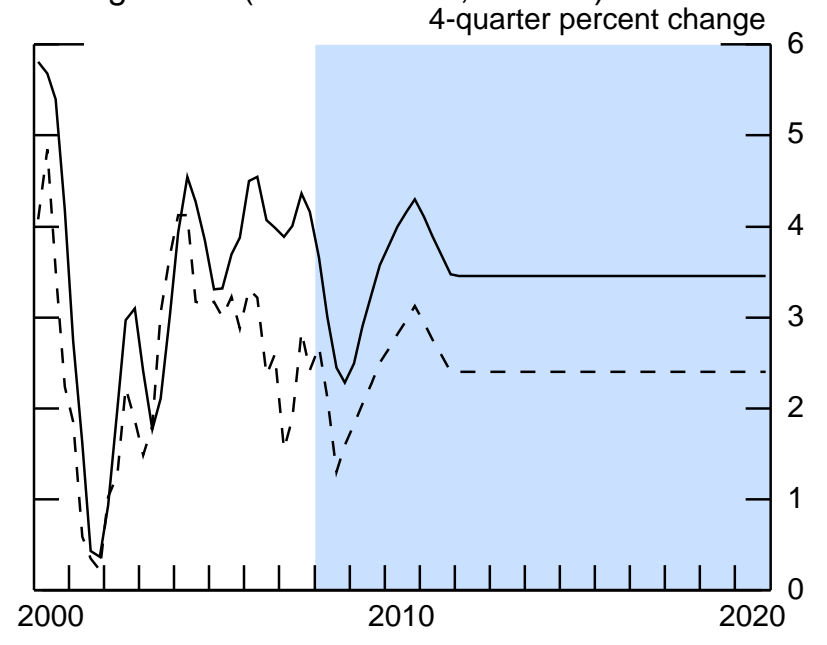

US Short \& Long-Term Interest Rates

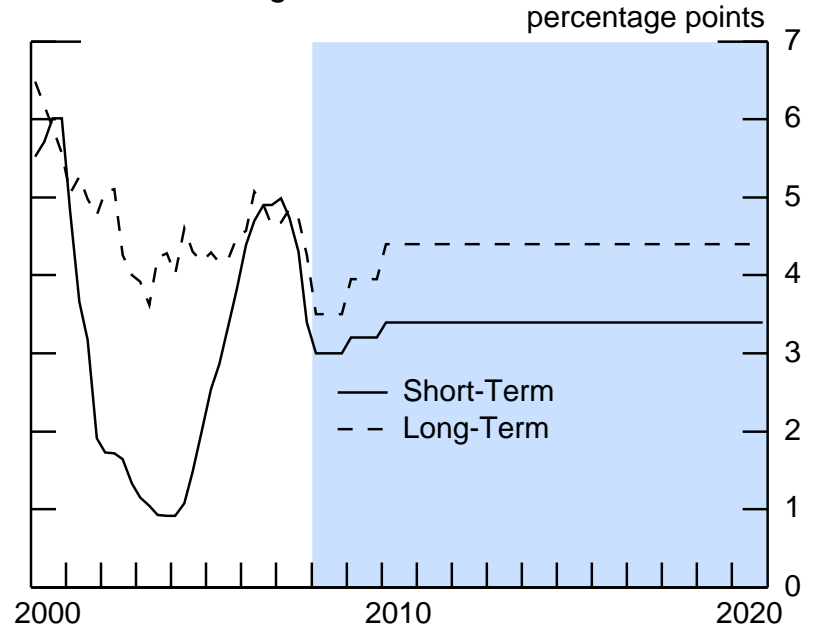

Rate of Return on Direct Investment

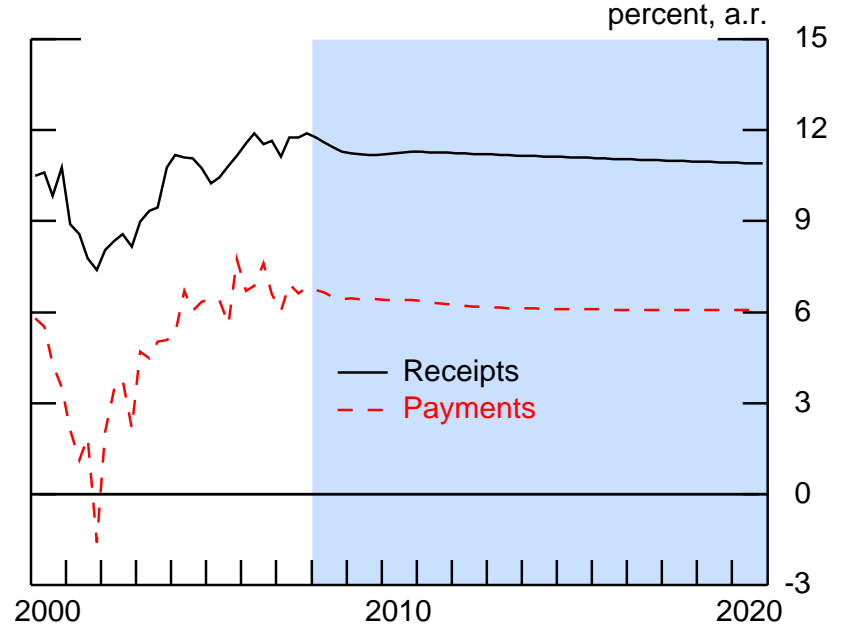




\section{Extended Baseline Projection}

Real Exports

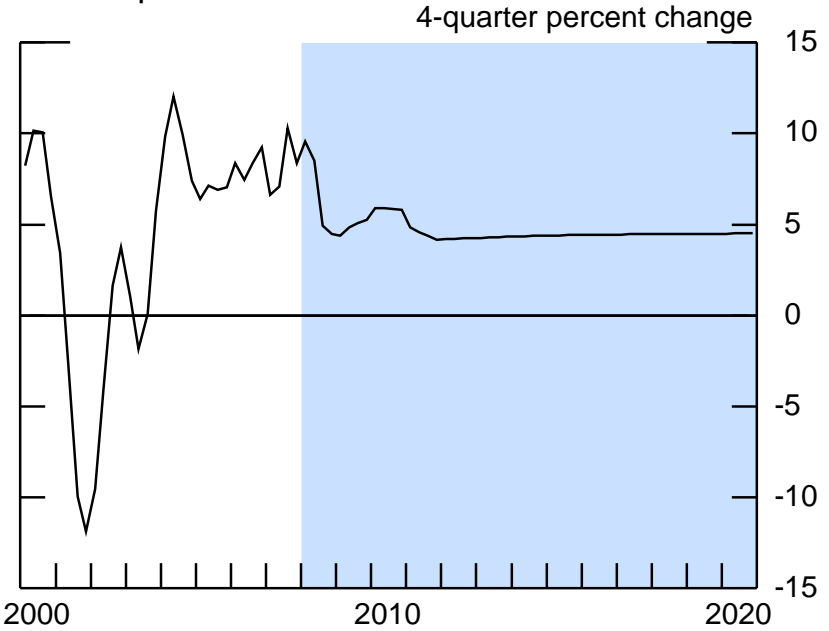

Nominal Trade Balance (Ex. Oil, dashed)

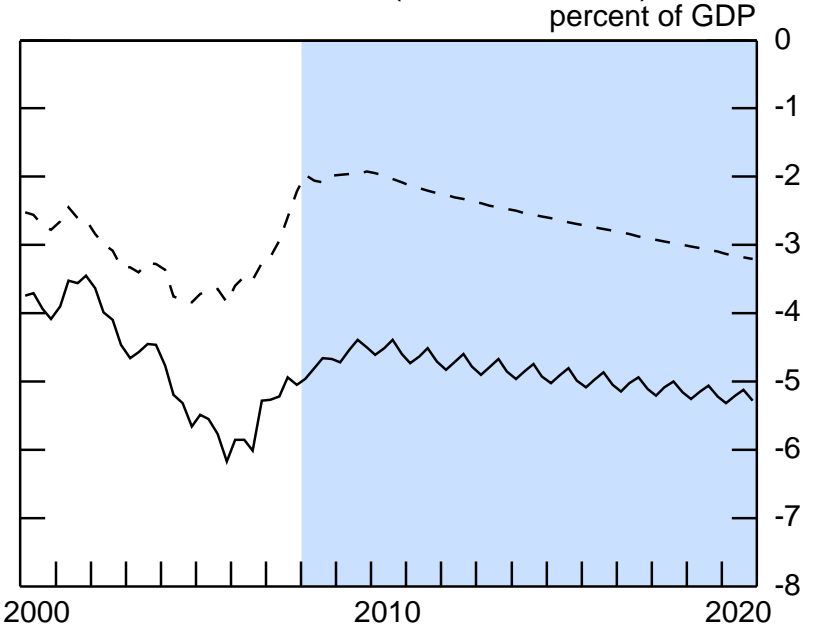

Net International Investment Position/GDP

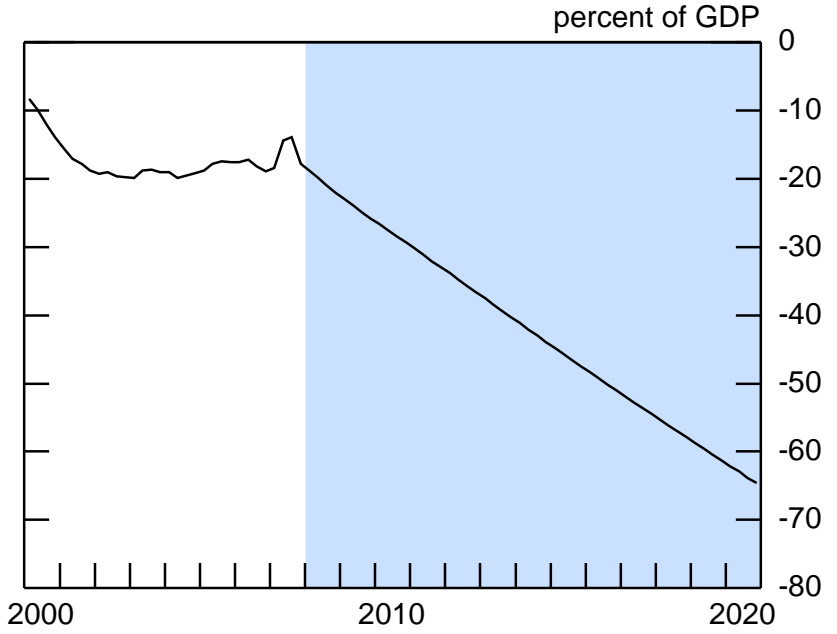

Real Imports

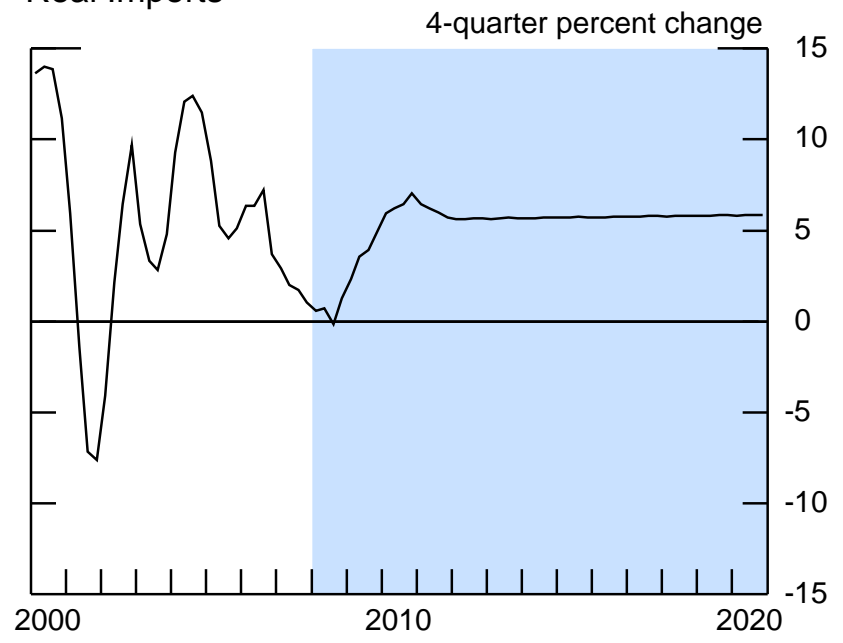

Current Account Balance

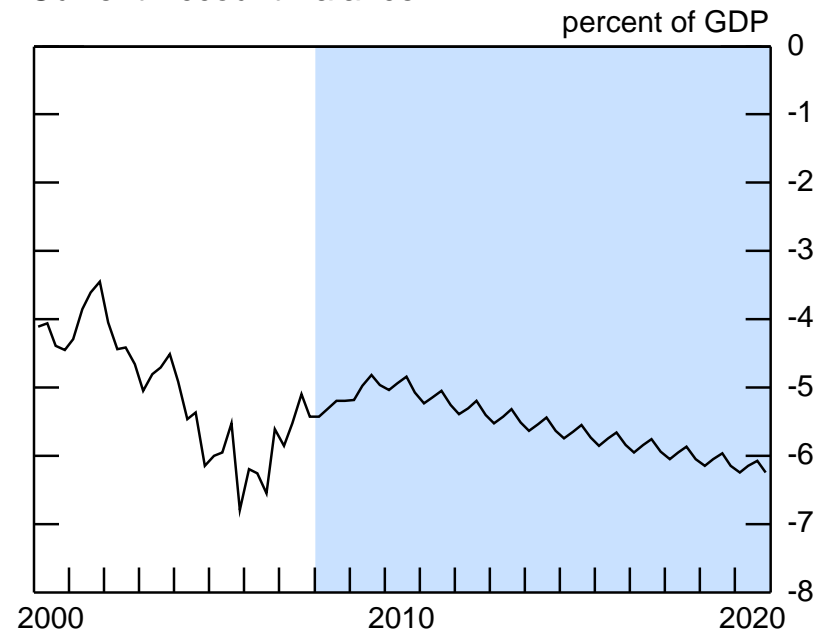

Net Investment Income

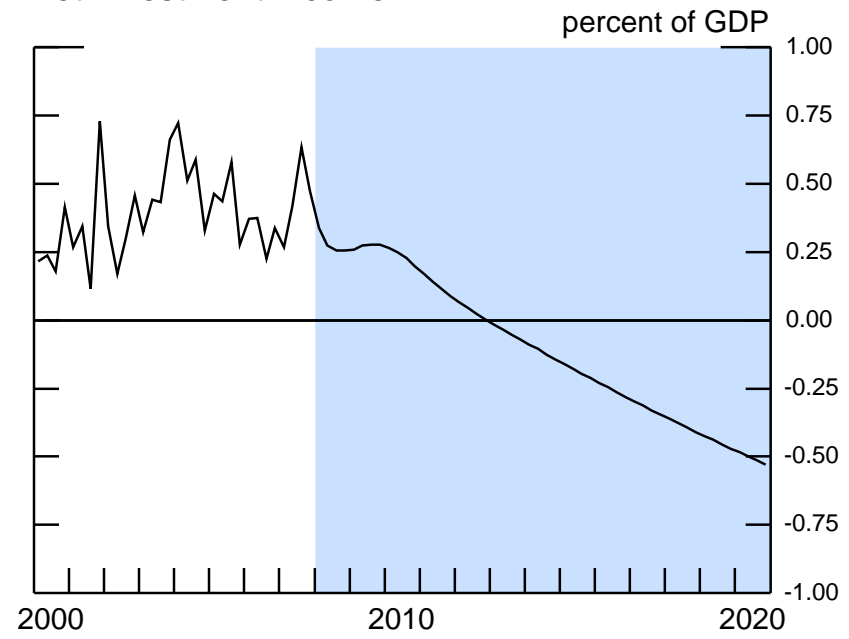




\section{Extended Baseline Projection}

Gross Investment Positions

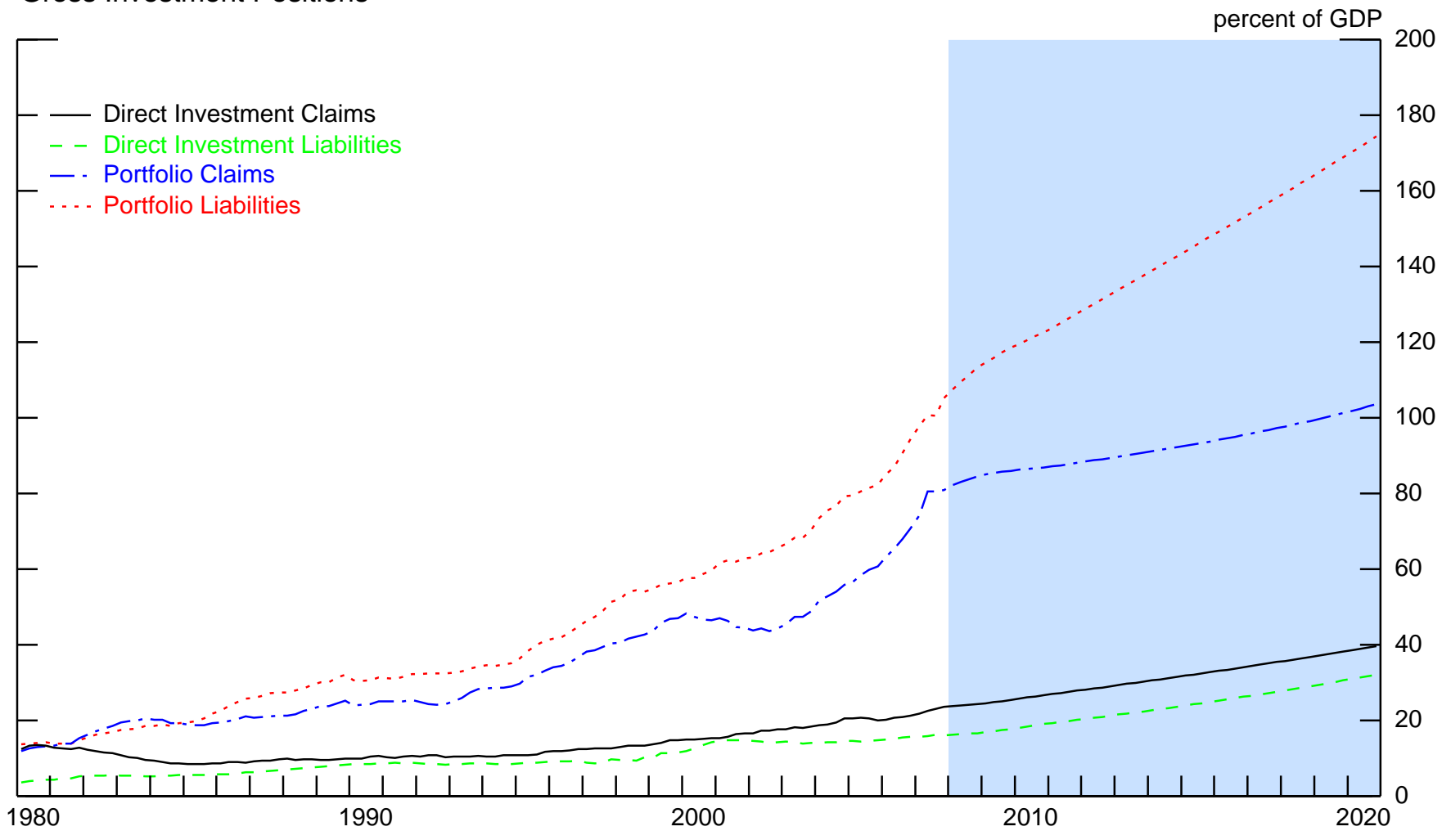

Rates of Return

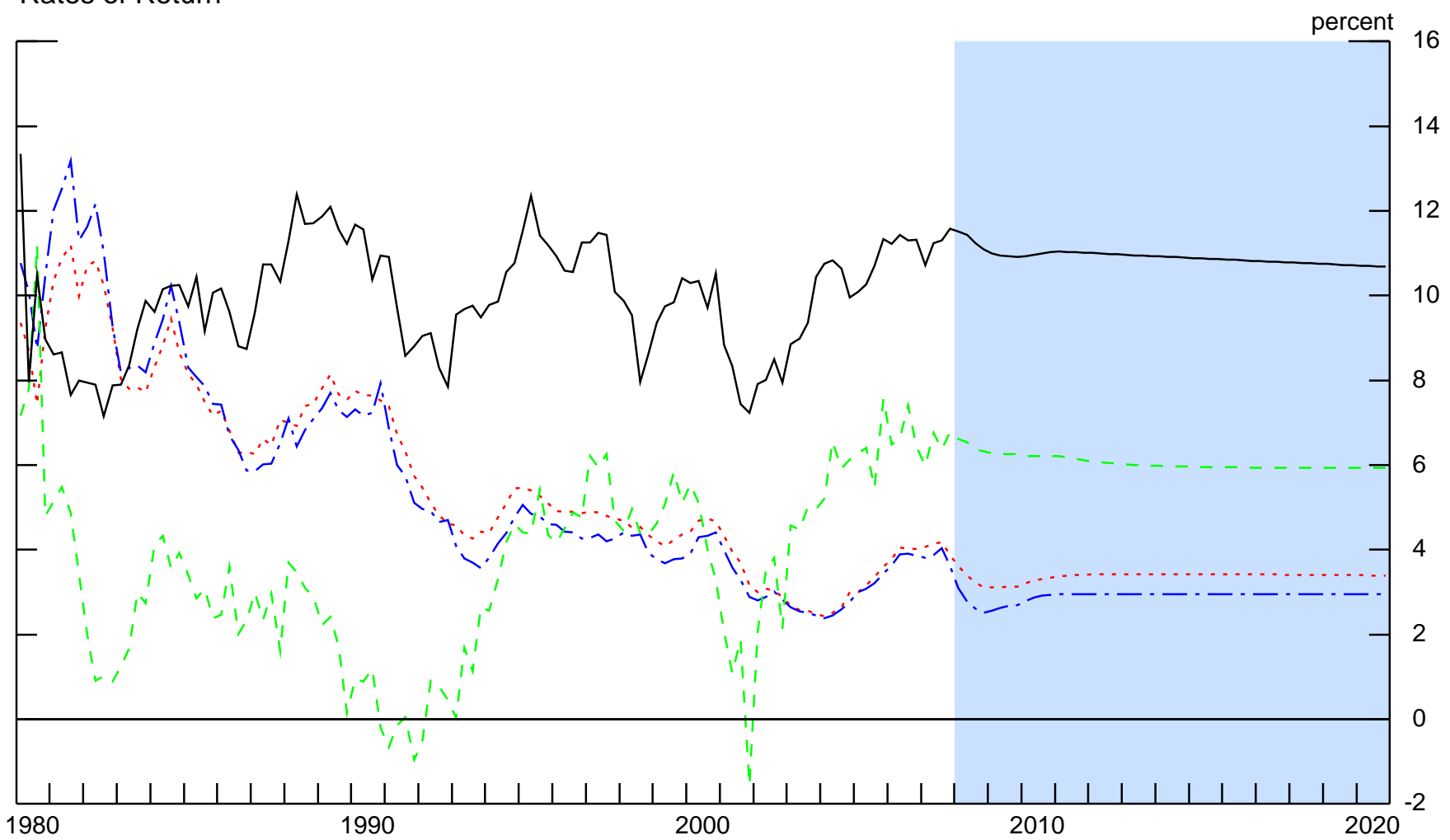




\section{Alternative Projections}

Black: Baseline Green: U.S. Growth = Foreign Growth Red: Oil Prices Rise

Blue: Dollar Depreciation and Higher Interest Rates Magenta: Higher Foreign Growth

Real Exchange Rate

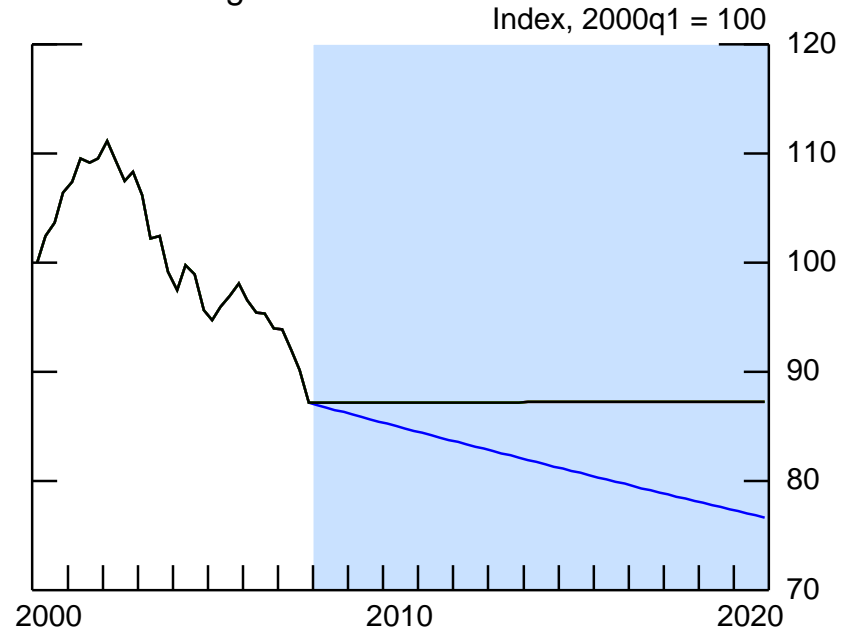

Oil Import Price

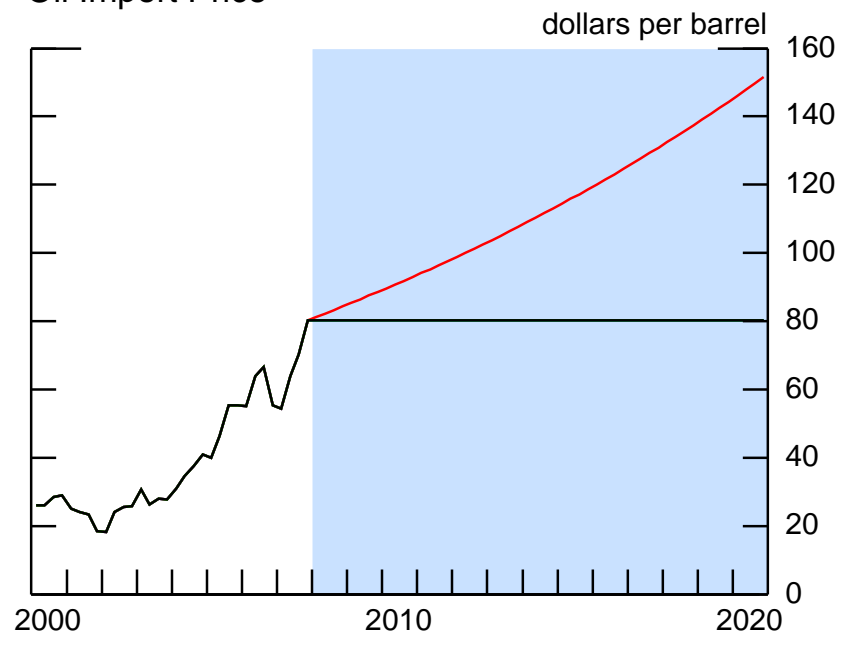

Rate of Return on Overall Portfolio Investment

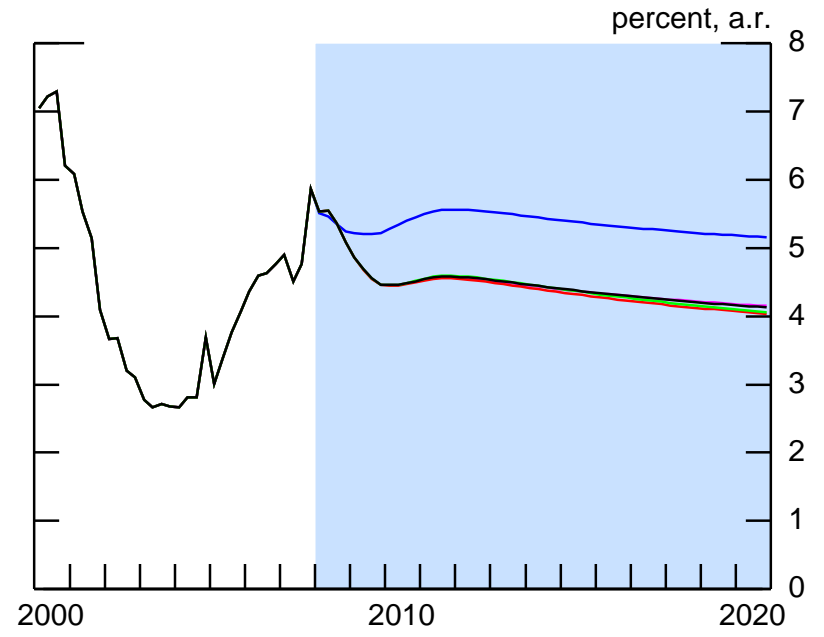

Foreign GDP (with US GDP, dashed)

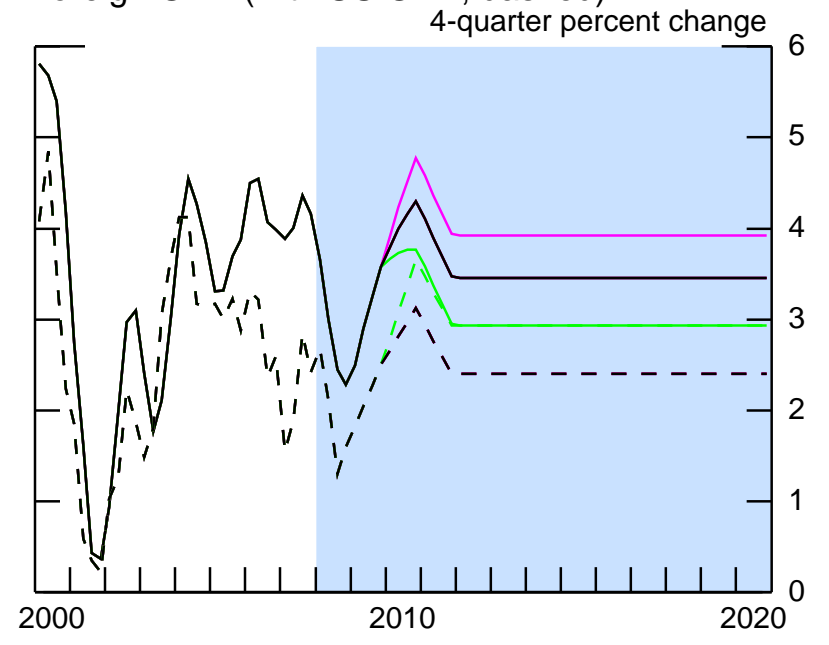

US Short \& Long-Term Interest Rates

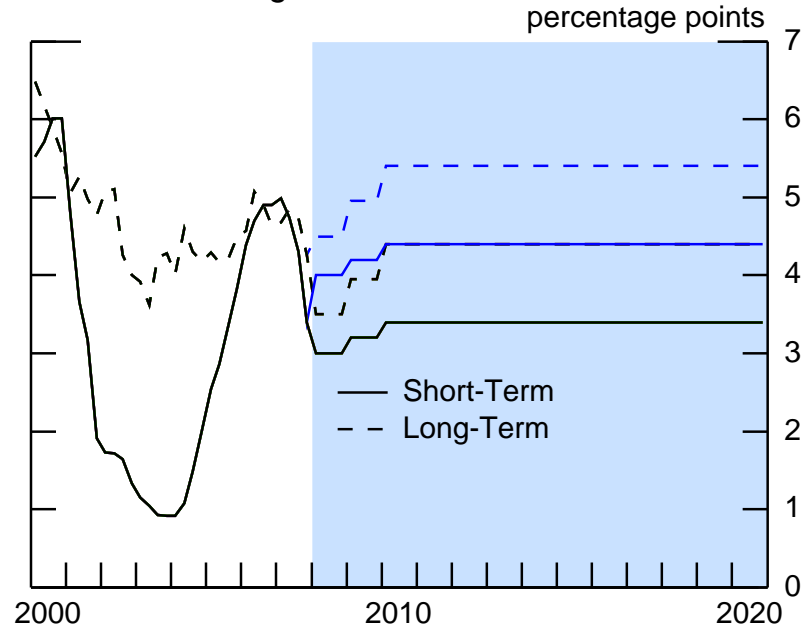

Rate of Return on Direct Investment

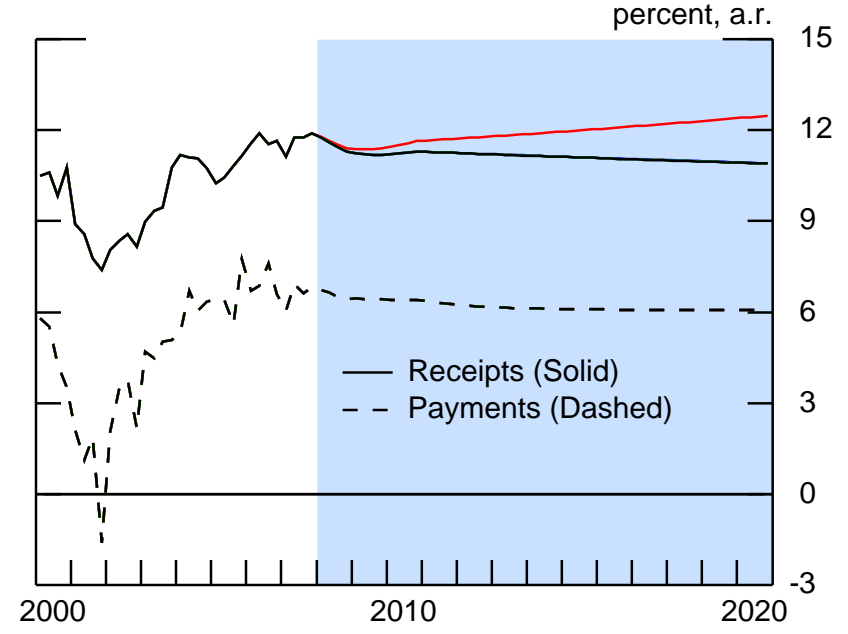




\section{Alternative Projections}

Black: Baseline Green: U.S. Growth = Foreign Growth Red: Oil Prices Rise Blue: Dollar Depreciation and Higher Interest Rates Magenta: Higher Foreign Growth

Real Exports

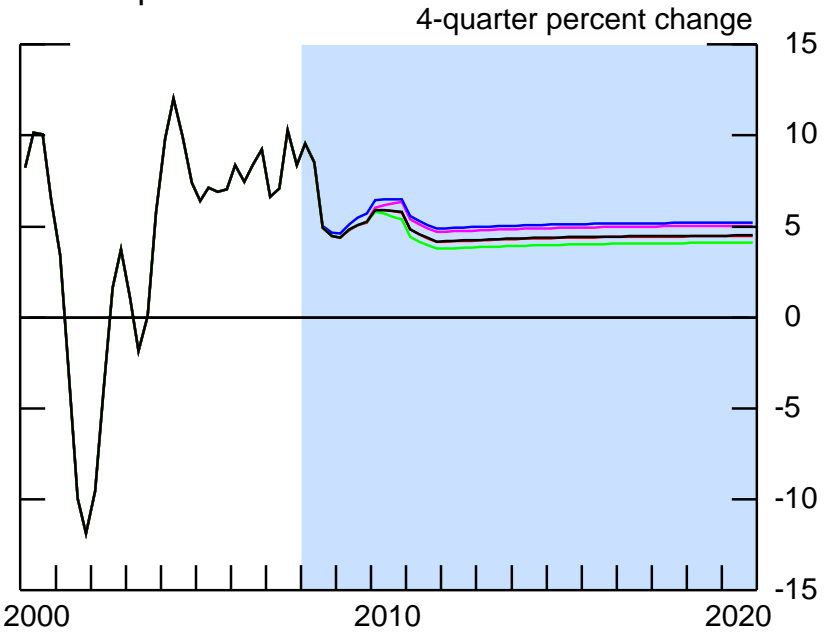

Nominal Trade Balance (Ex. Oil, dashed)

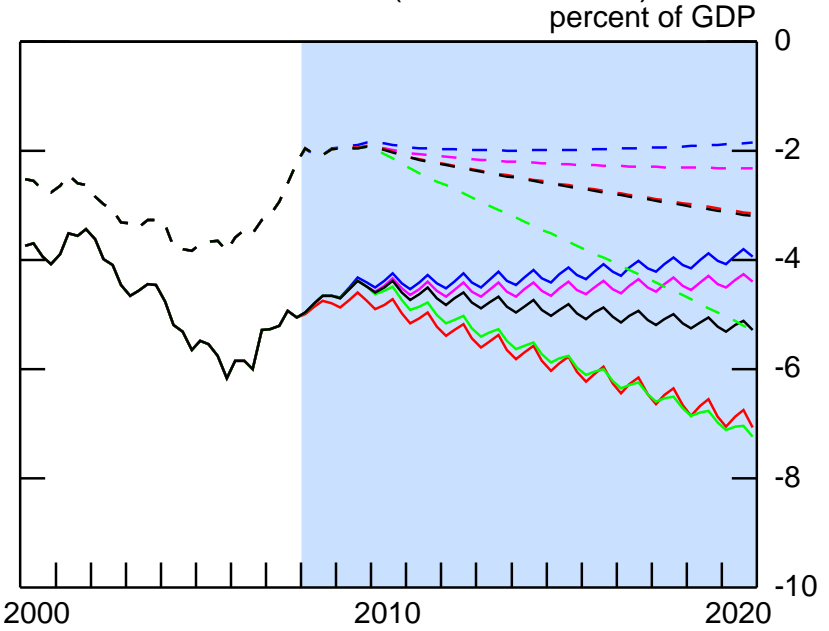

Net International Investment Position/GDP

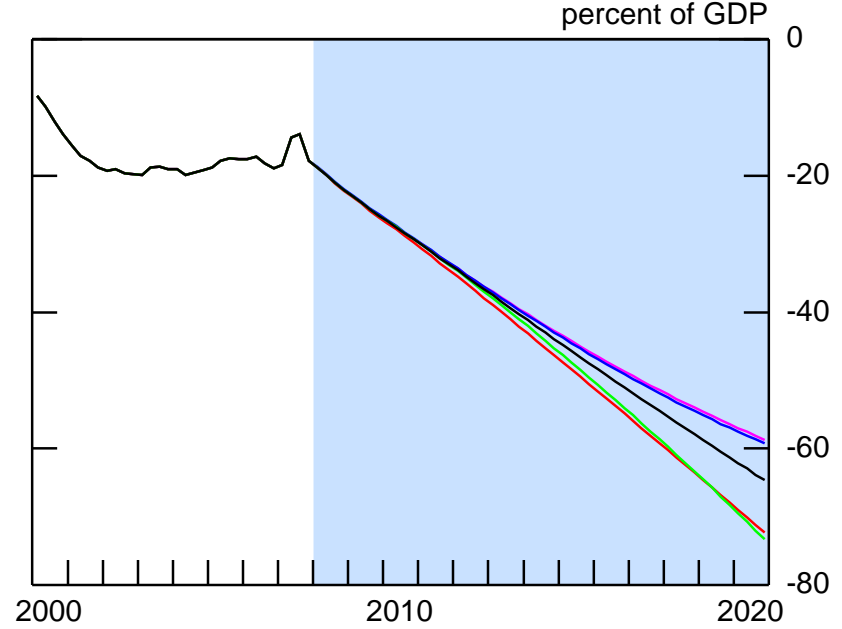

Real Imports

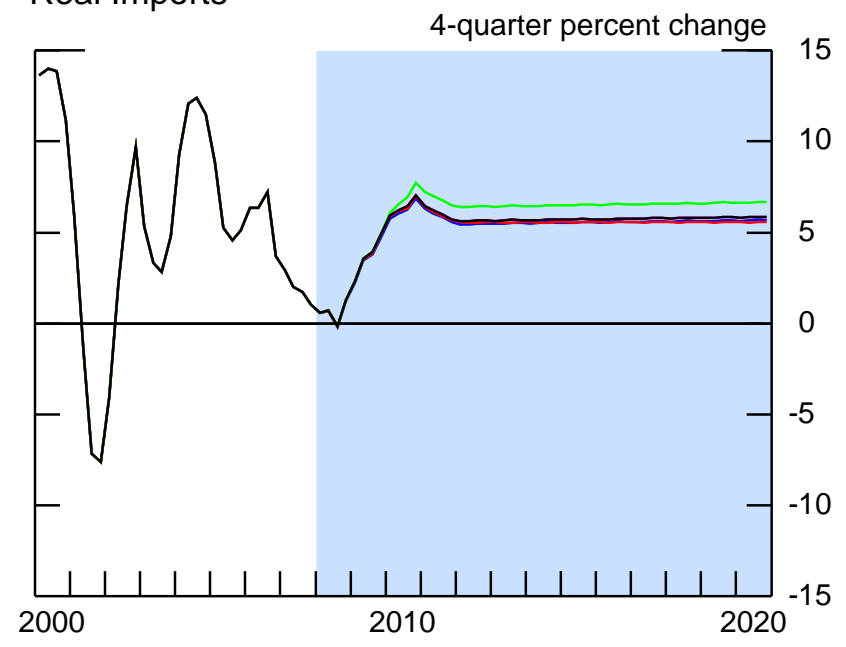

Current Account Balance

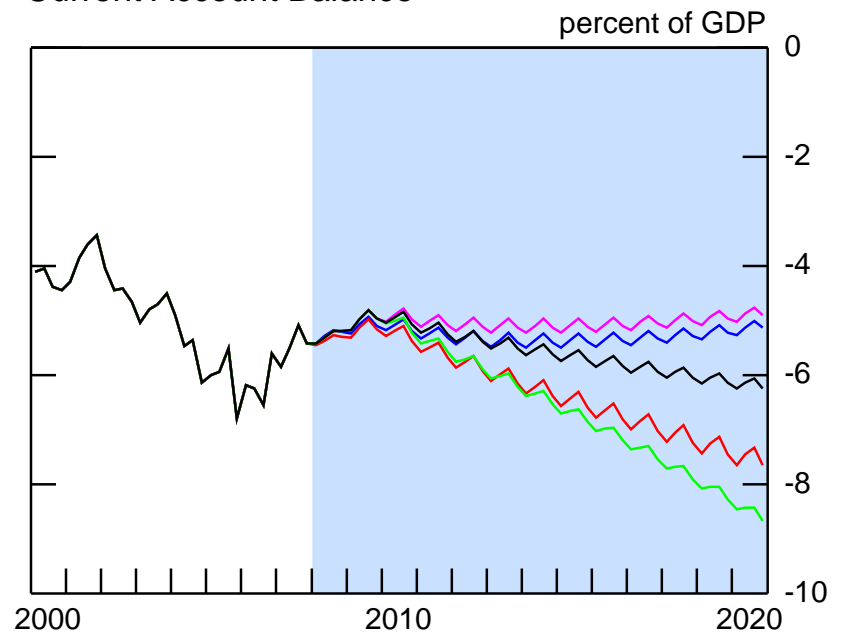

Net Investment Income

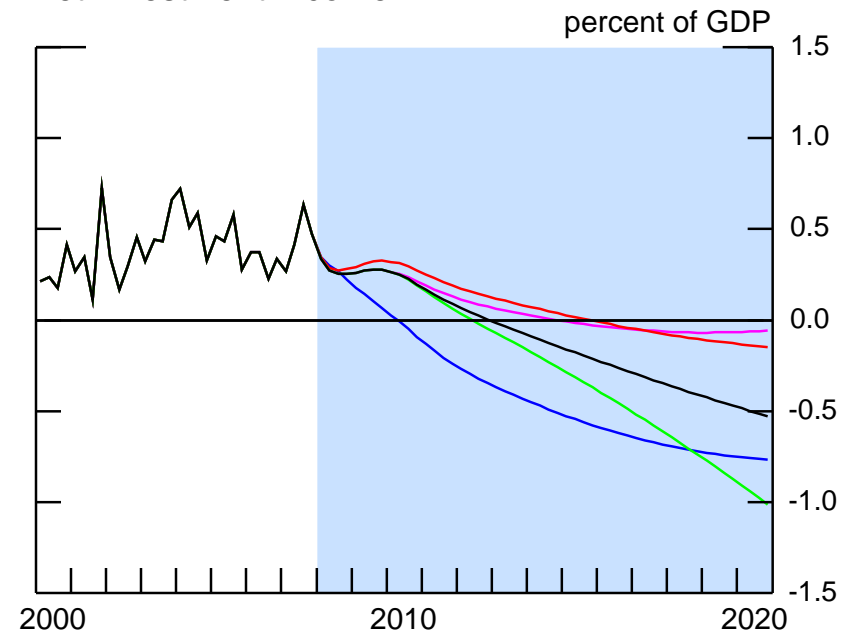




\section{Ex Post Historical Simulation}

\section{Black: History Red: Model begins in 1995}

Real Exchange Rate

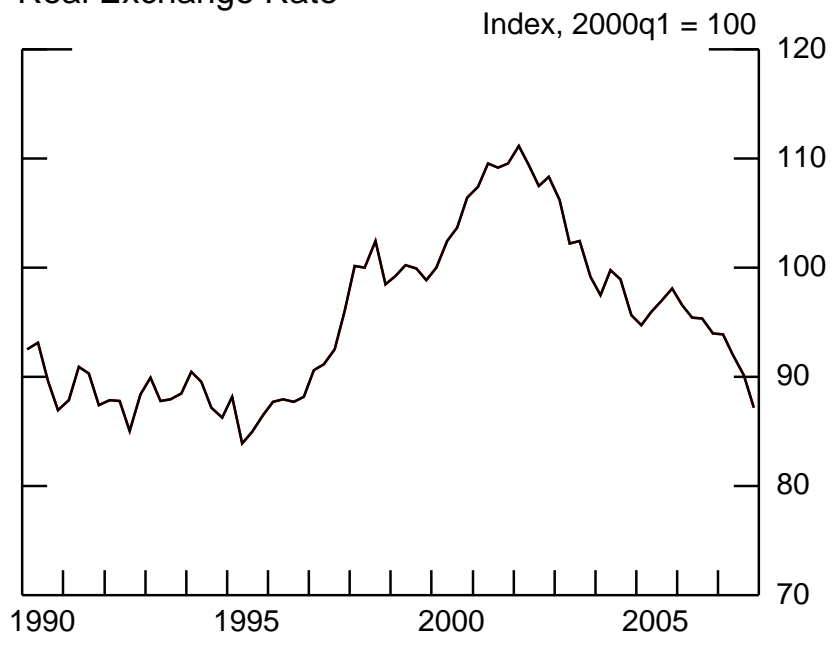

Oil Import Price

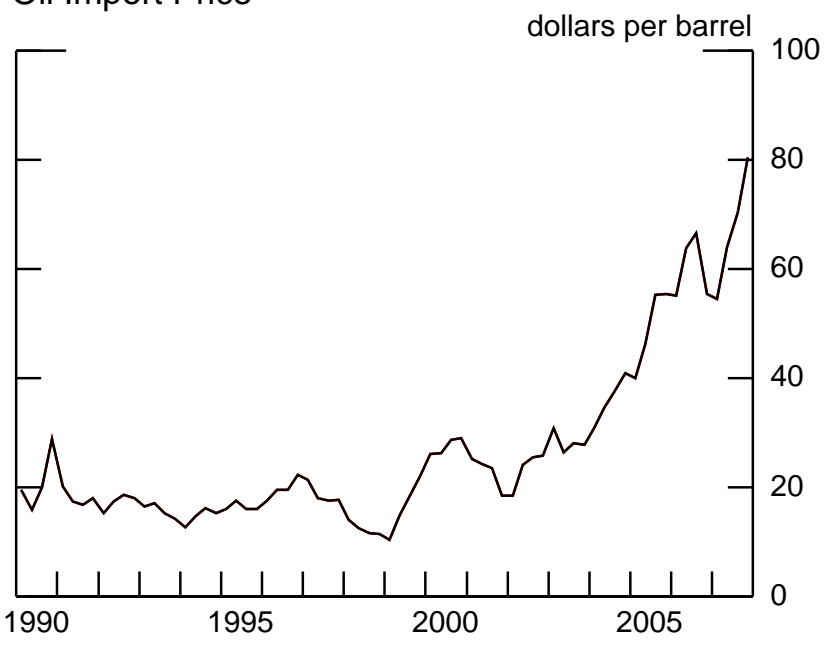

Rate of Return on Overall Portfolio Investment

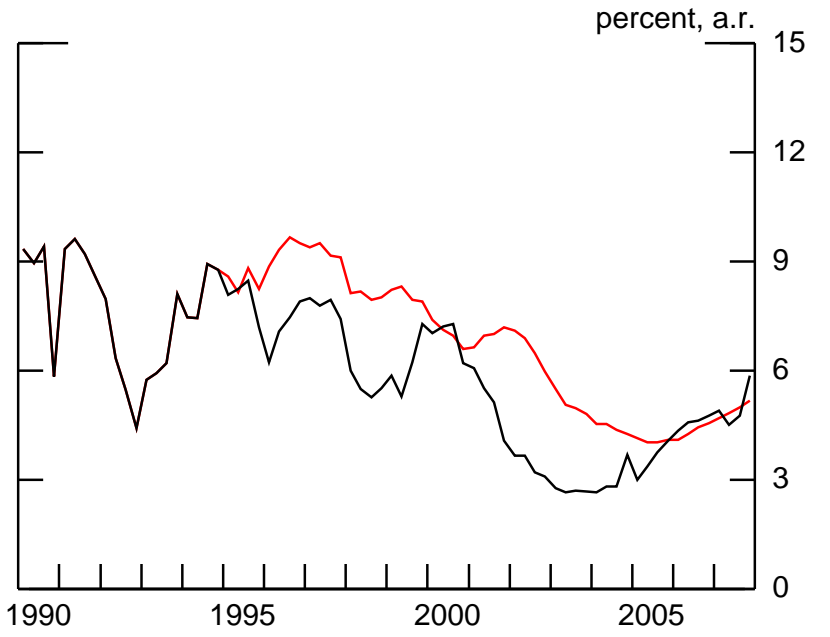

Foreign GDP (with US GDP, dashed)

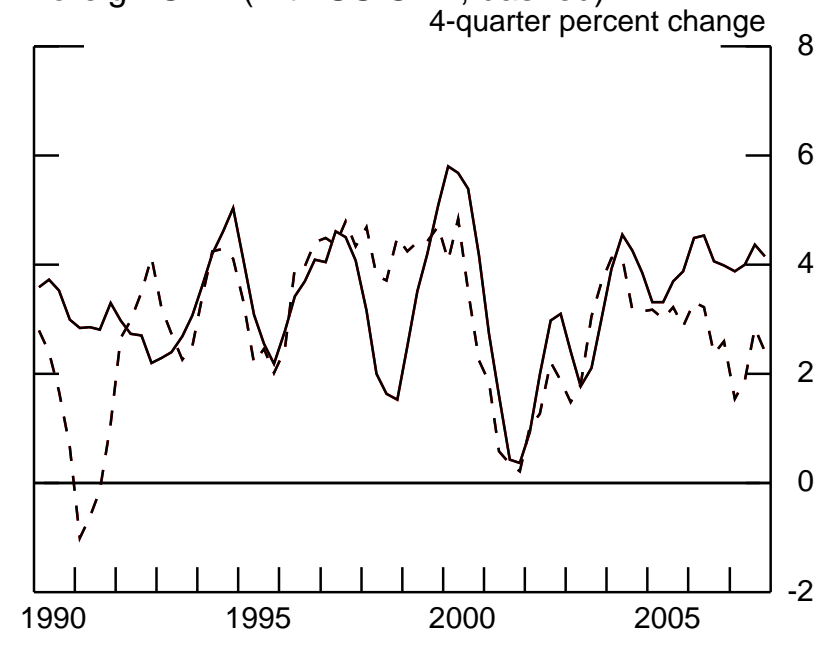

US Short \& Long-Term Interest Rates

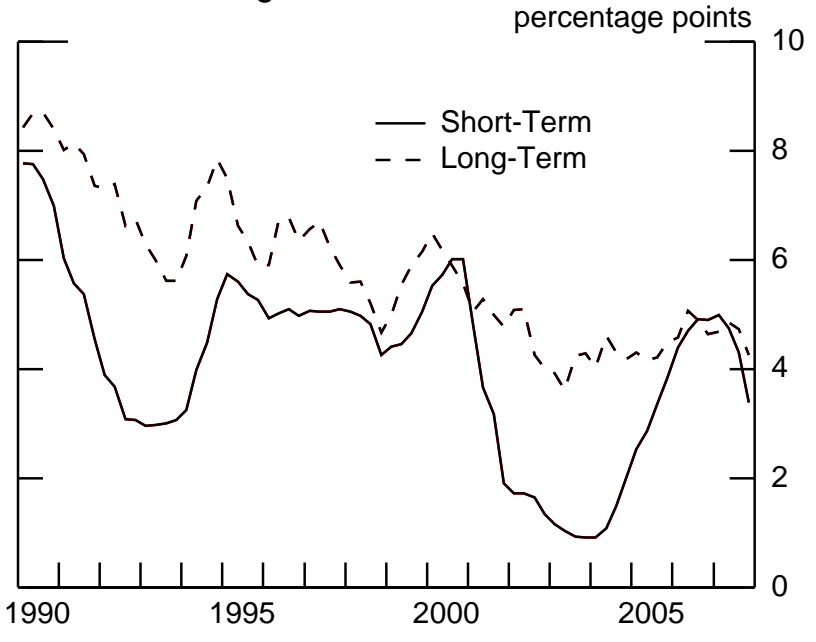

Rate of Return on Direct Investment

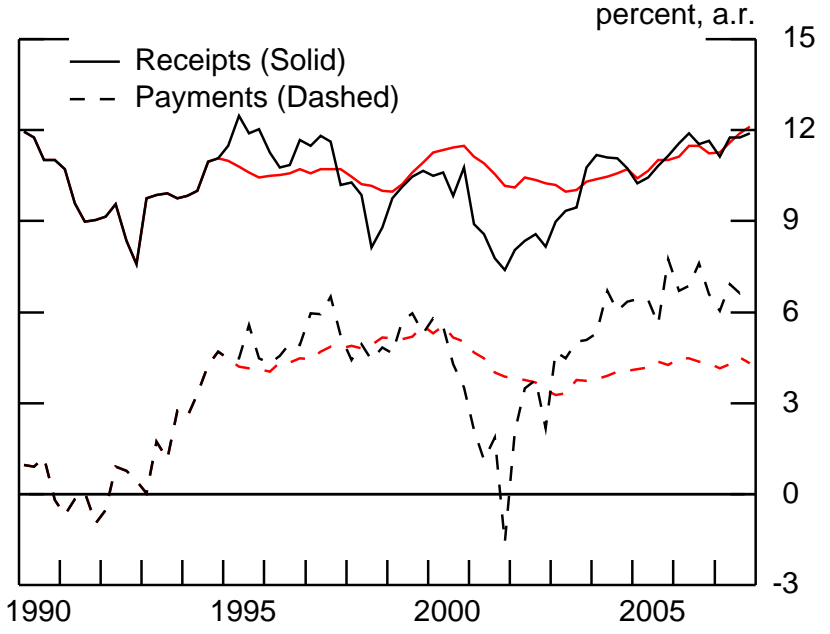




\section{Ex Post Historical Simulation}

\section{Black: History Red: Model begins in 1995}

Real Exports

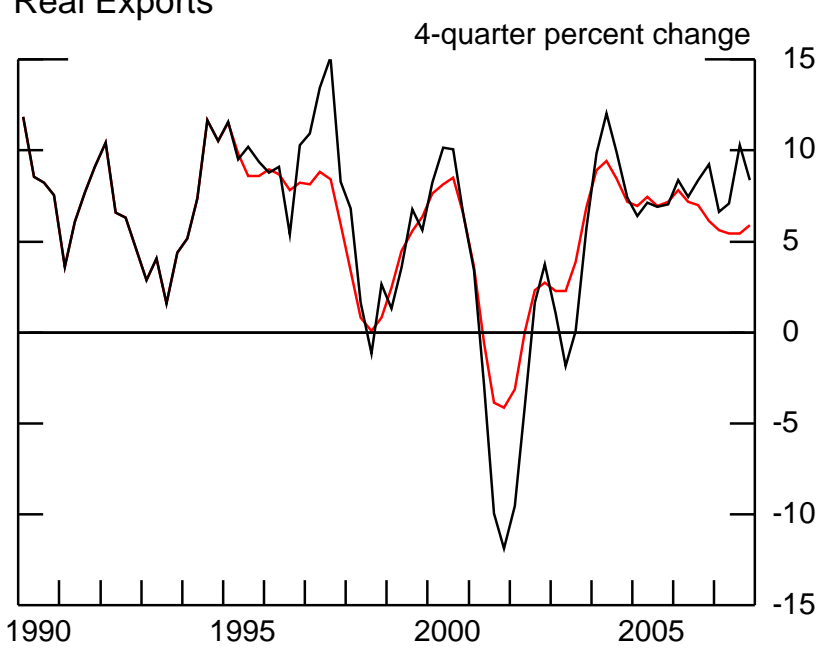

Nominal Trade Balance (Ex. Oil, dashed)

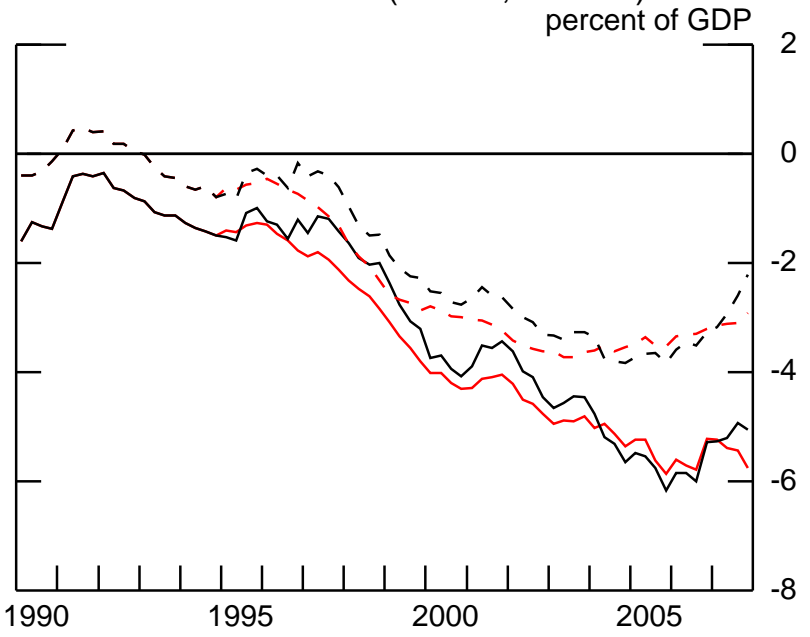

Net International Investment Position/GDP

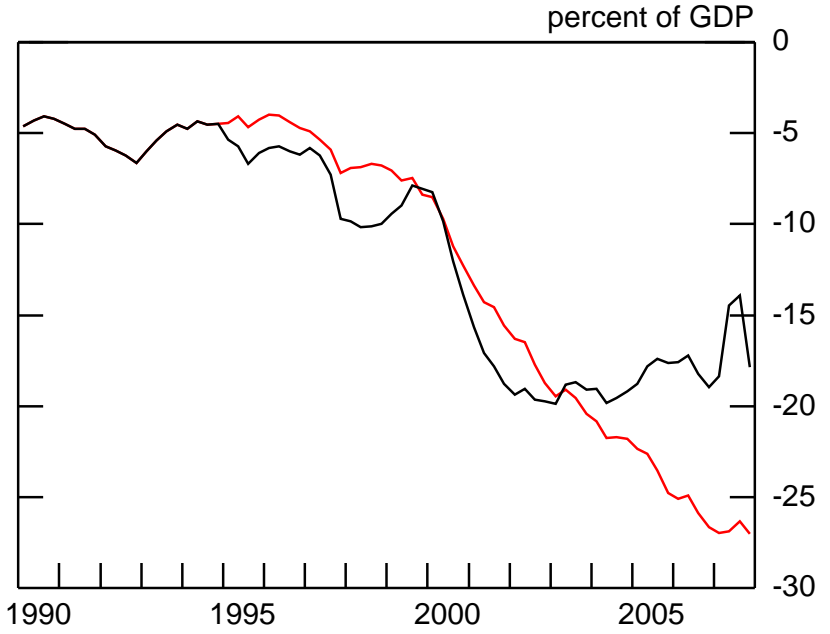

Real Imports

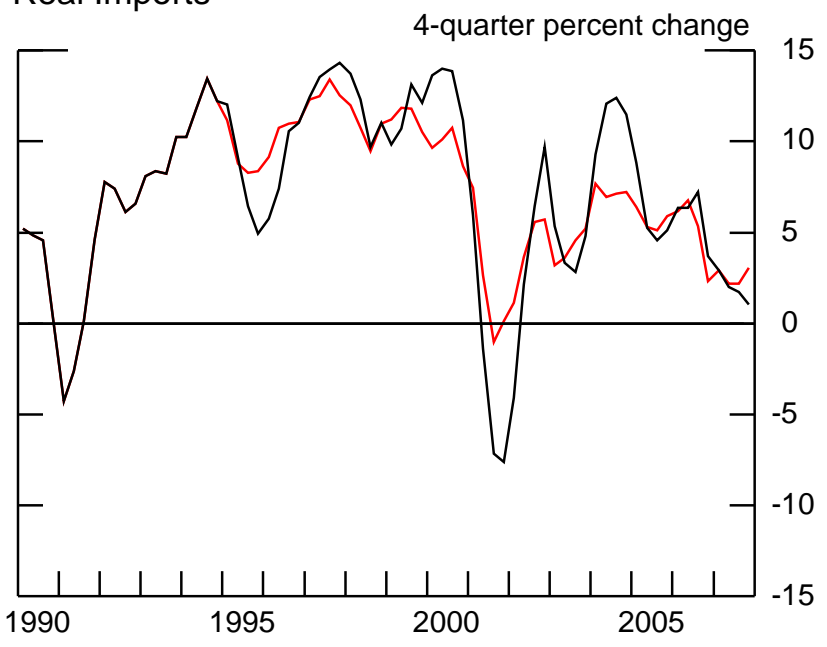

Current Account Balance

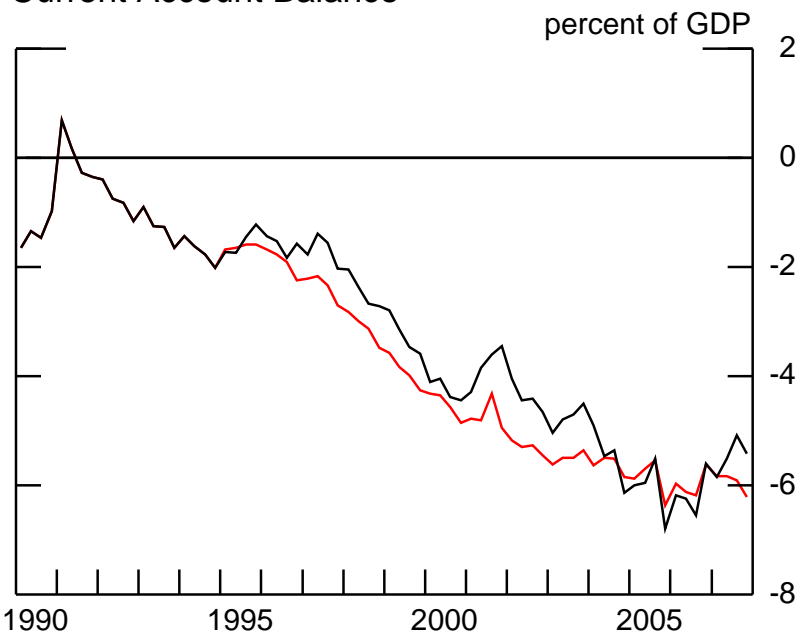

Net Investment Income

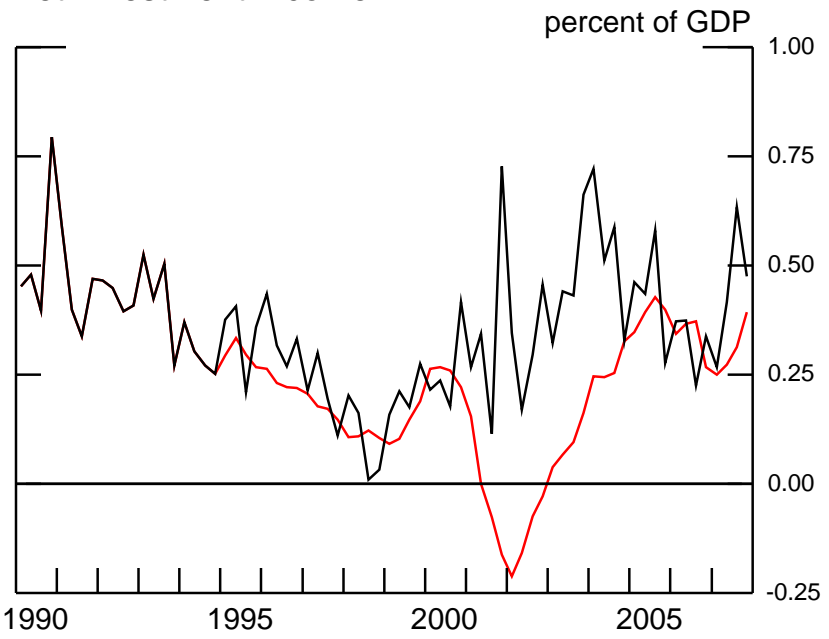


Net International Investment Position as a Share of GDP, 2006

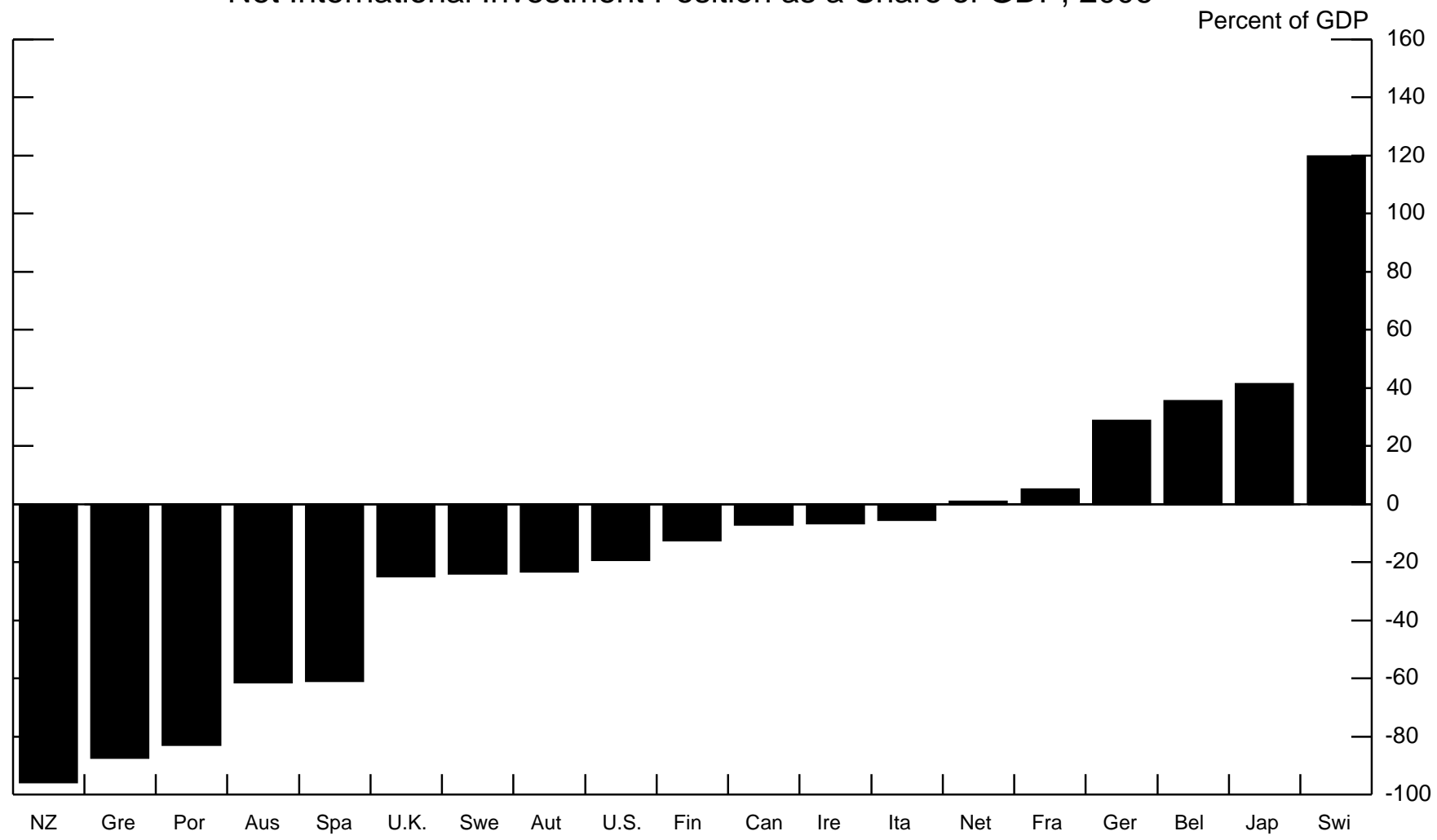

Source: IMF International Financial Statistics. Sweden data from 2005.

Net Investment Income as a Share of GDP, 2006

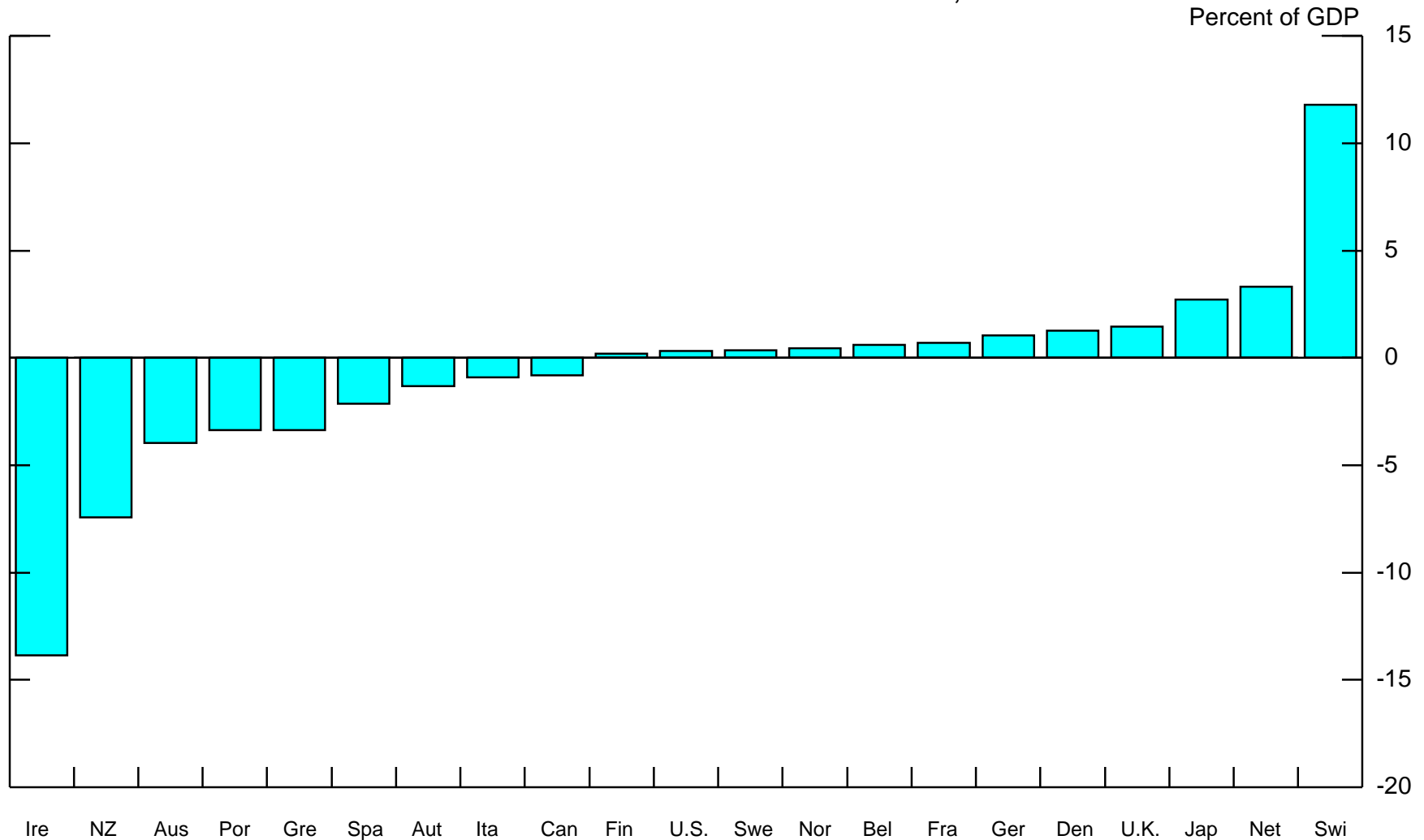

Source: IMF Balance of Payments Statistics. 
Net International Investment Position as a Share of Exports, 2006

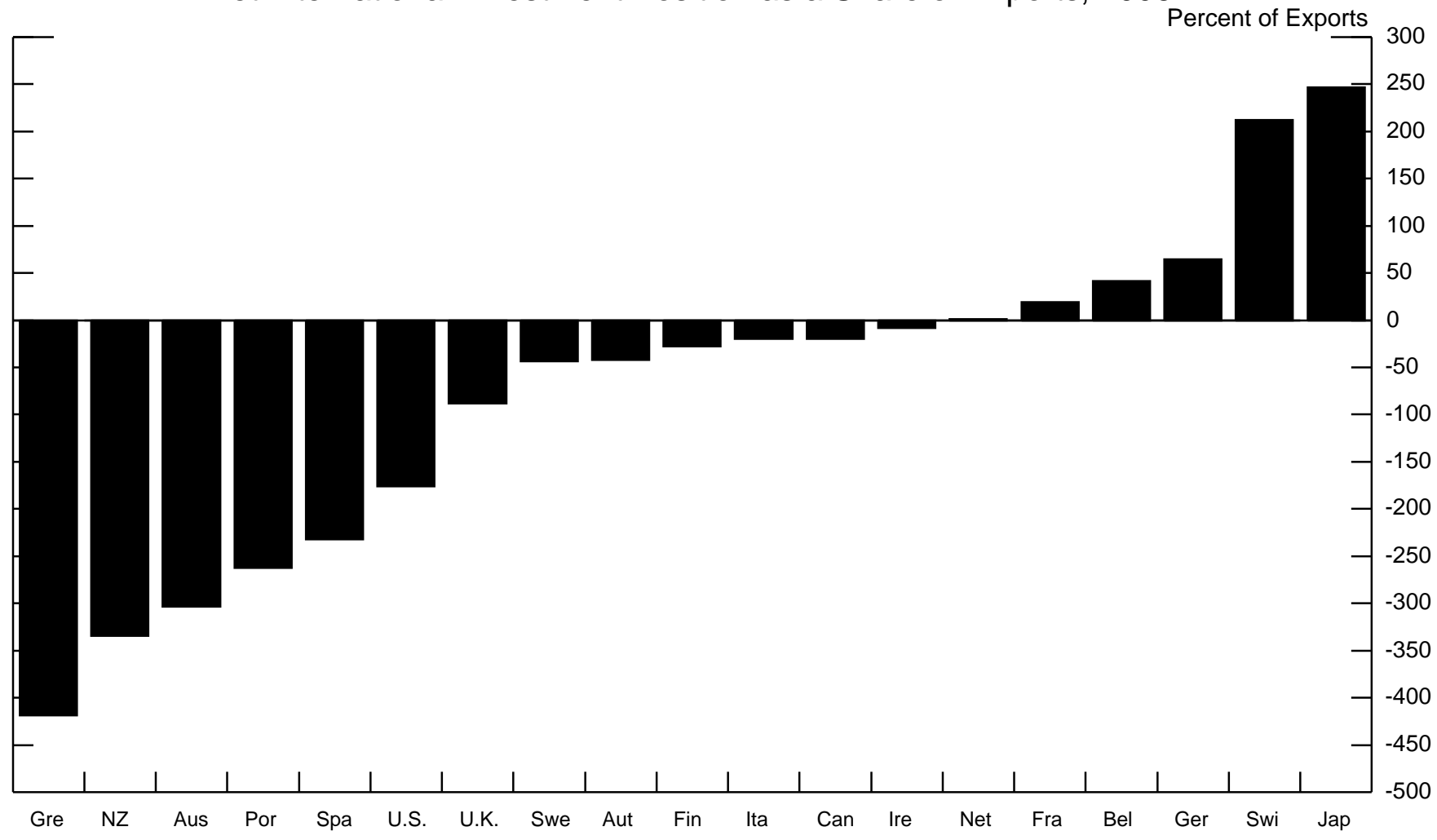

Source: IMF International Financial Statistics. Sweden data from 2005.

Net Investment Income as a Share of Exports, 2006

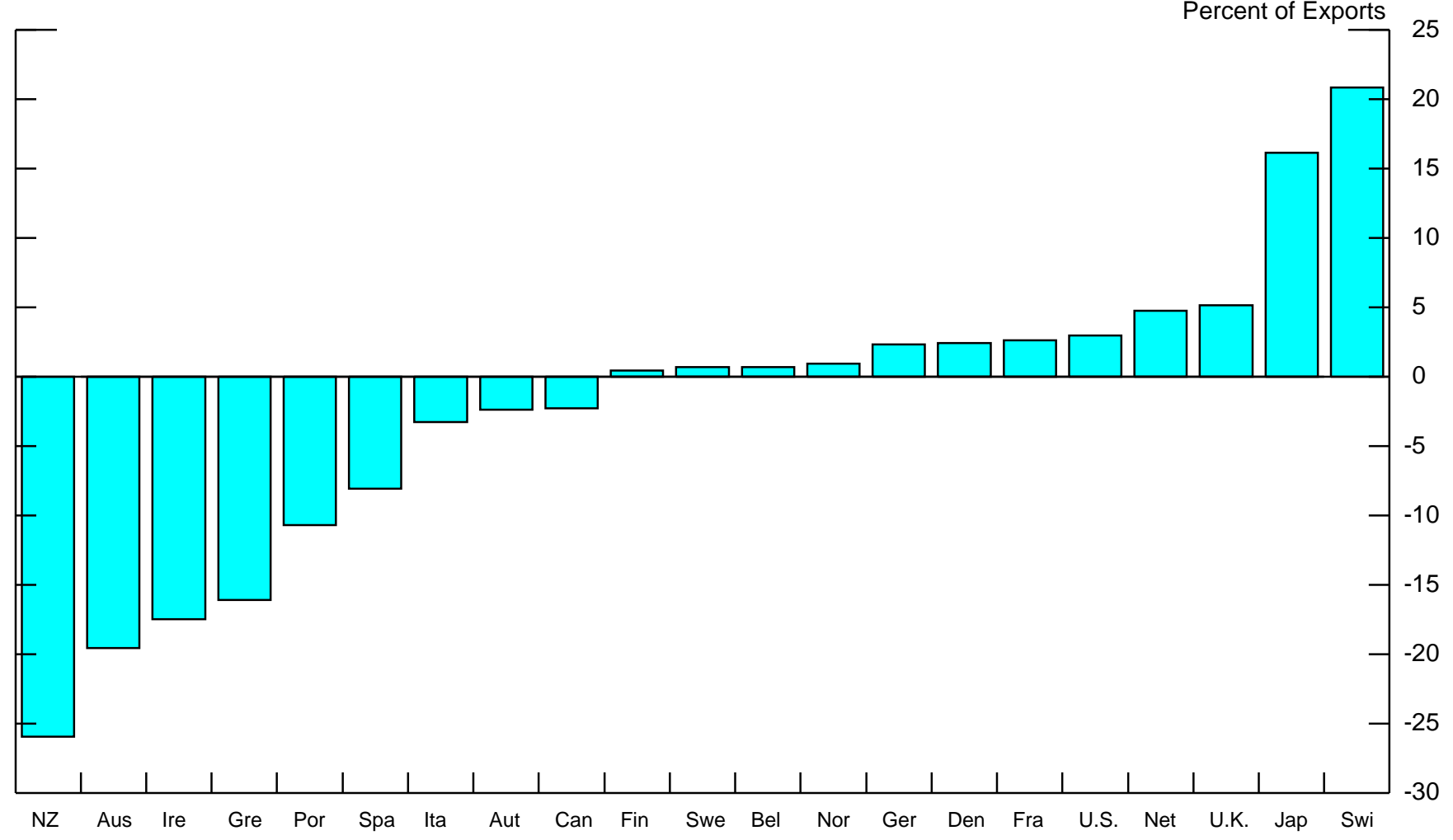

Source: IMF Balance of Payments Statistics. 
NIIP/GDP vs Net Investment Income/GDP, 2006

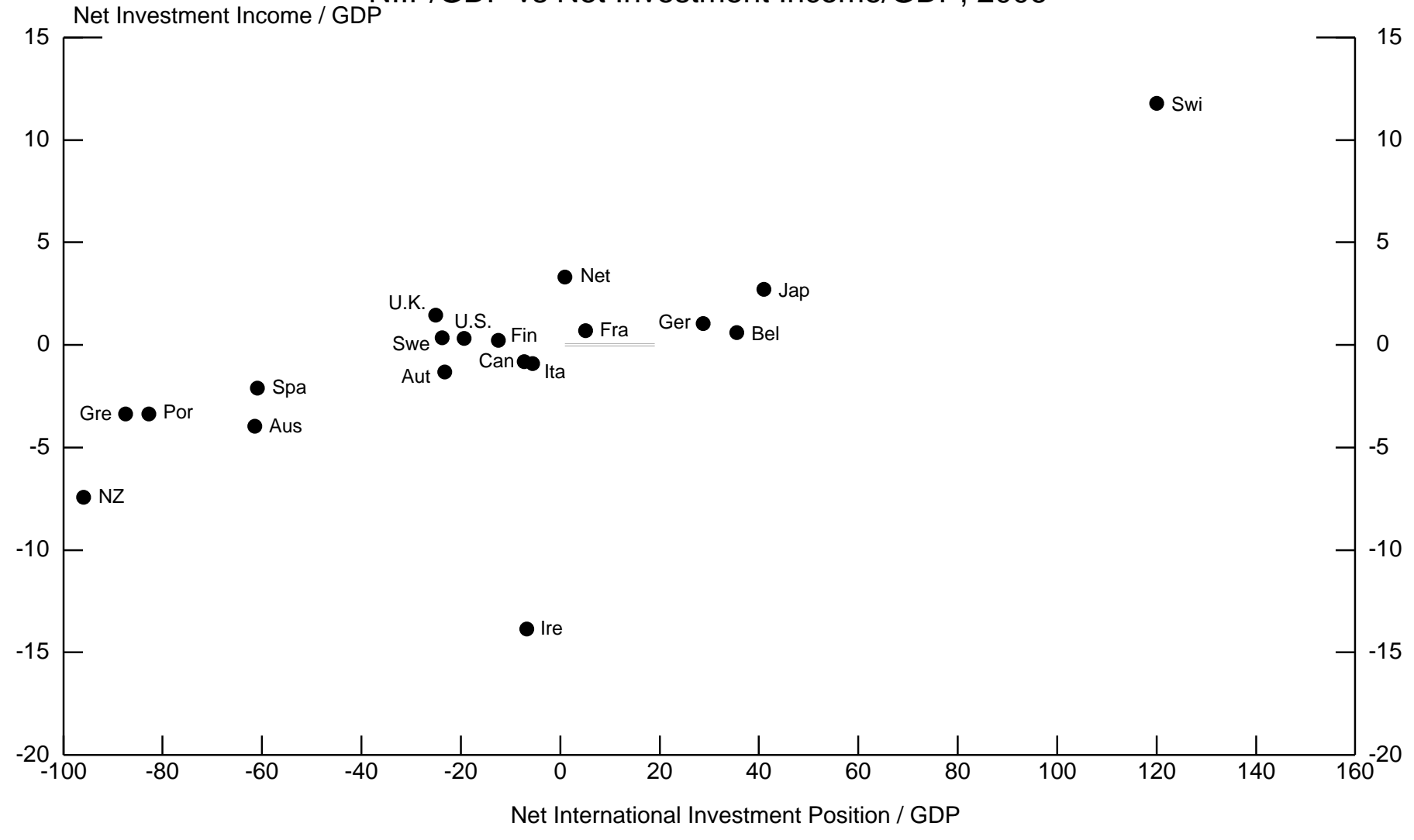


Net International Investment Position as a Share of GDP

(Measured at Year of Current Account Adjustment)

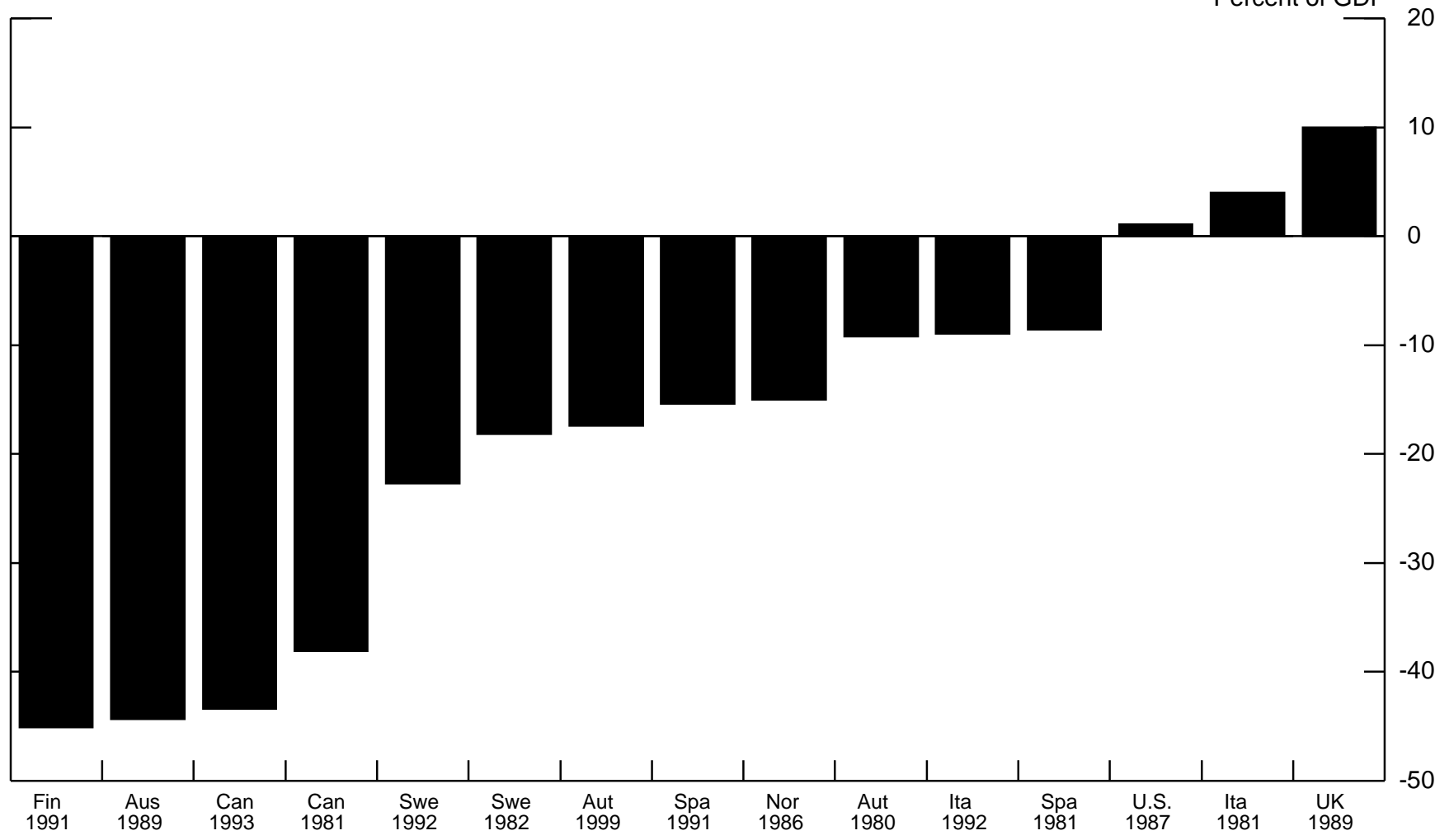

Source: IMF International Financial Statistics.

Net Investment Income as a Share of GDP

(Measured at Year of Current Account Adjustment)

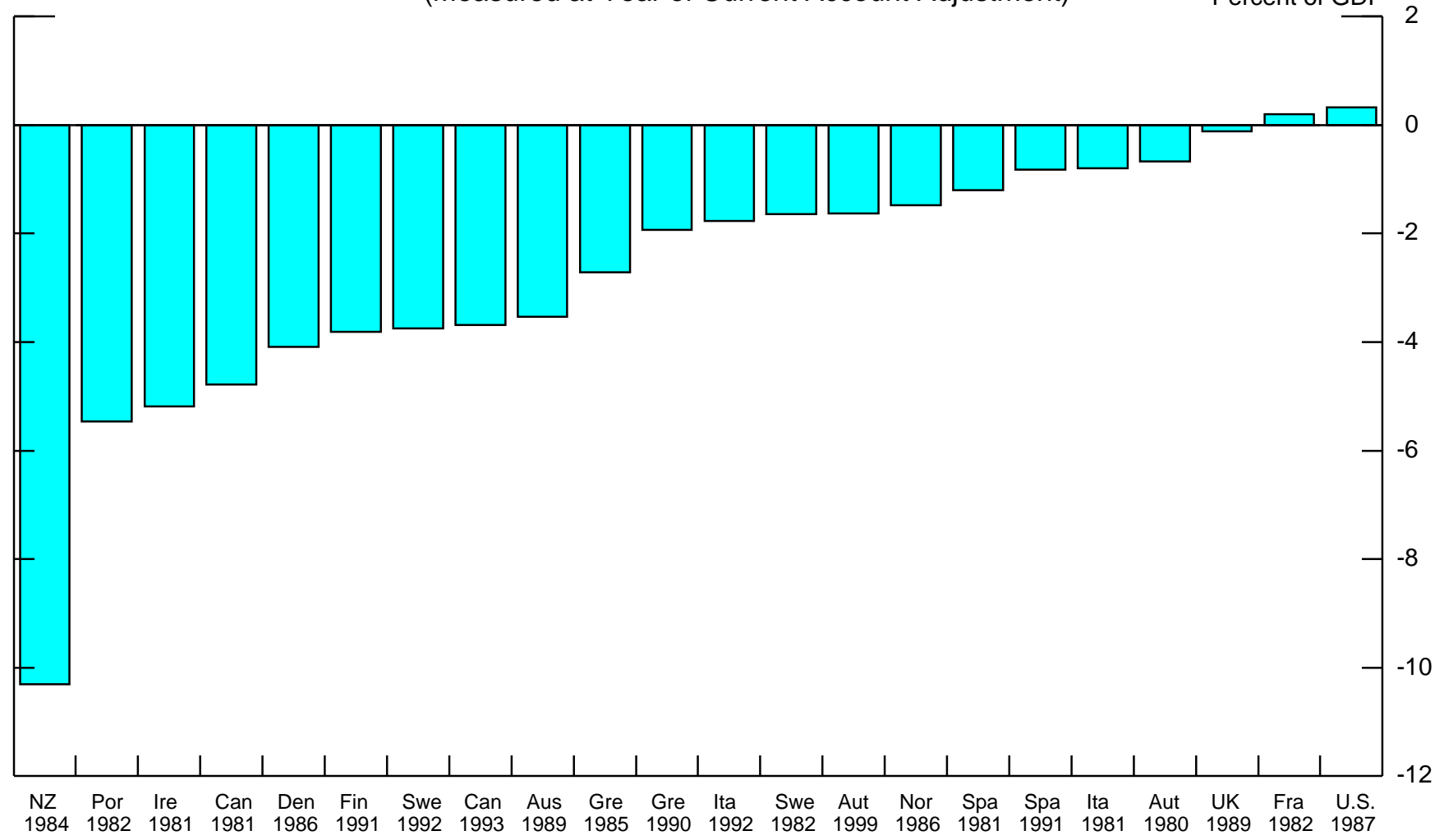

Source: IMF Balance of Payments Statistics. 


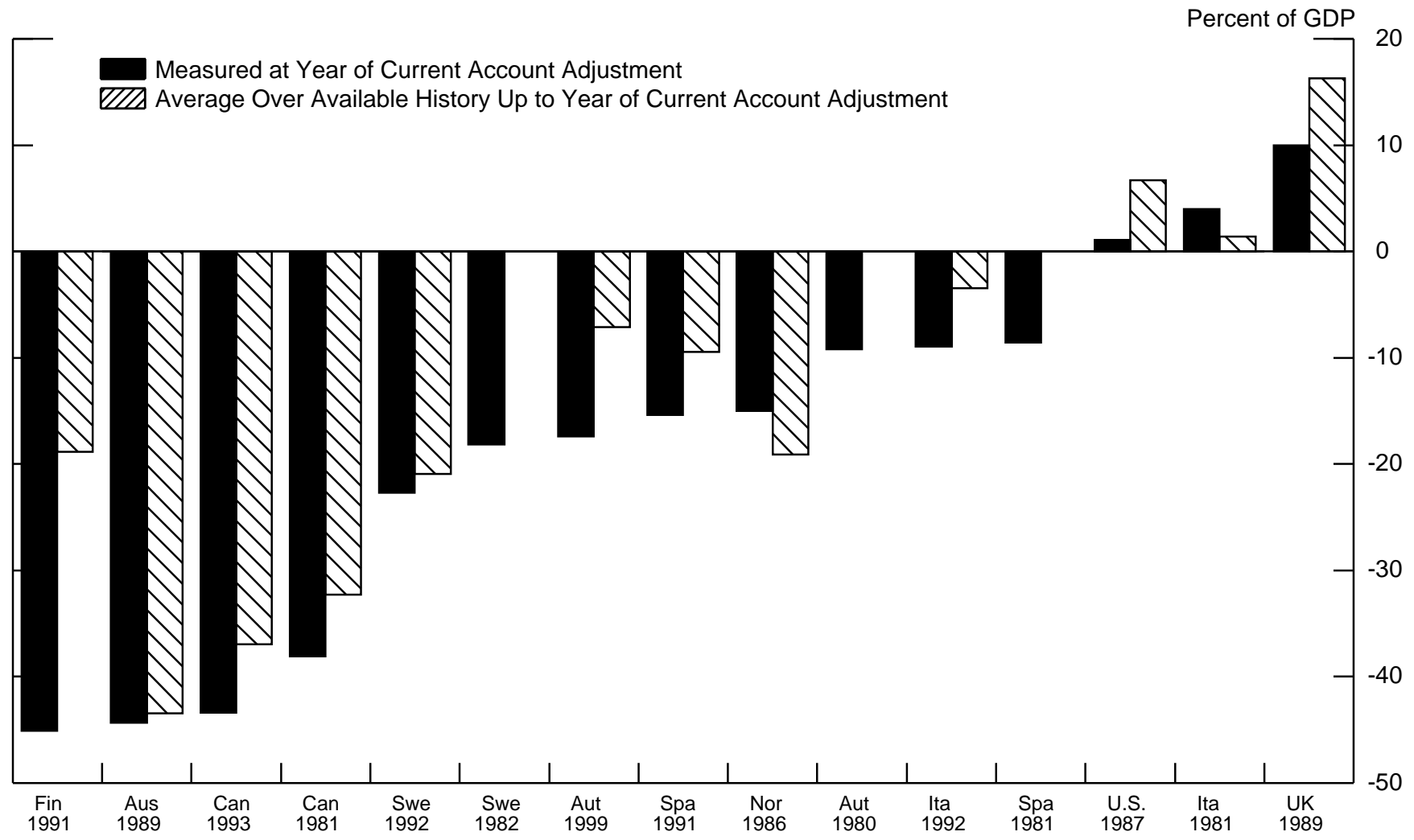

Source: IMF International Financial Statistics.

Net Investment Income as a Share of GDP

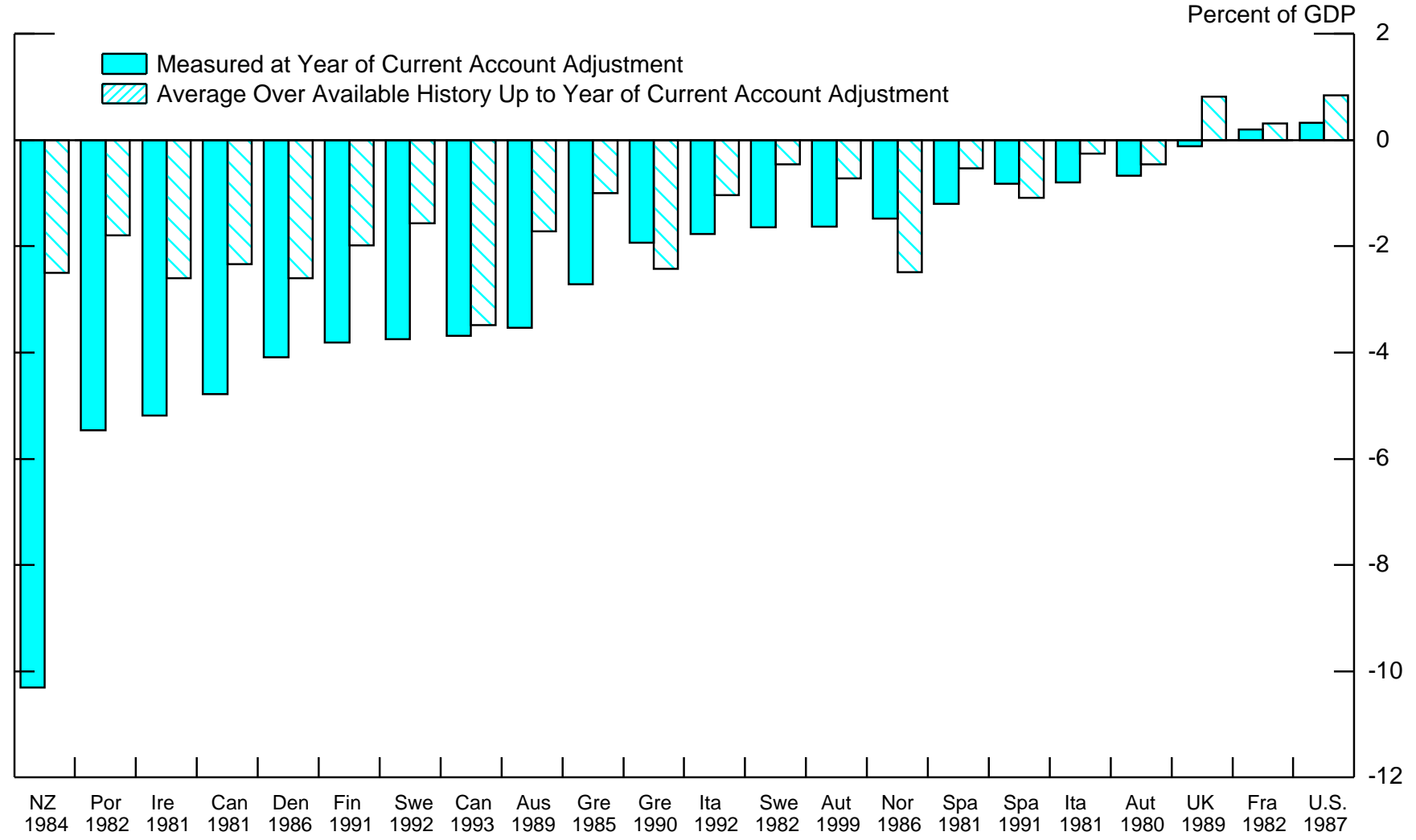

Source: IMF Balance of Payments Statistics. 


\section{Shares in World Market Capitalization}
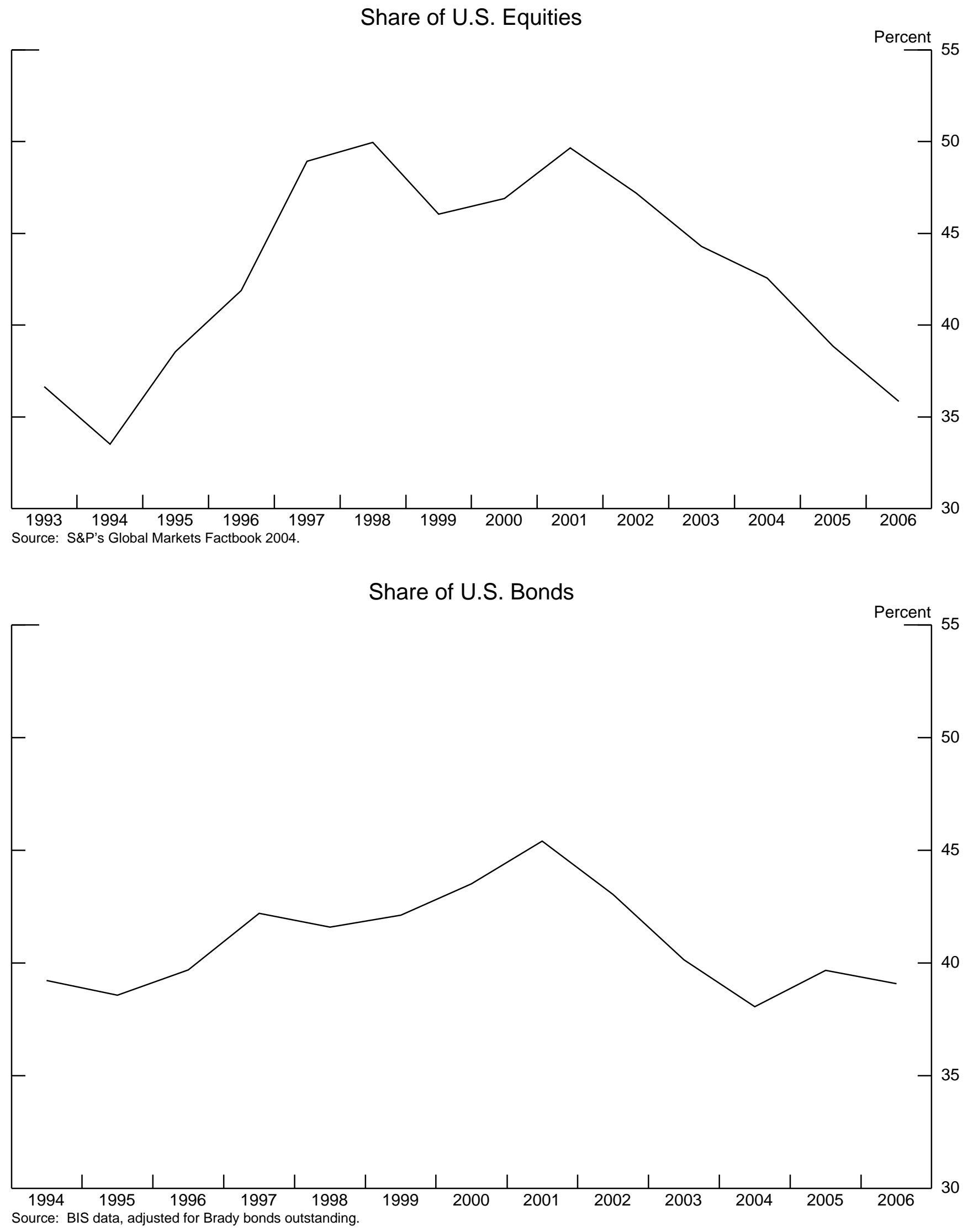
Share of U.S. and All External Equities in Total Equity Portfolios of Foreign Investors

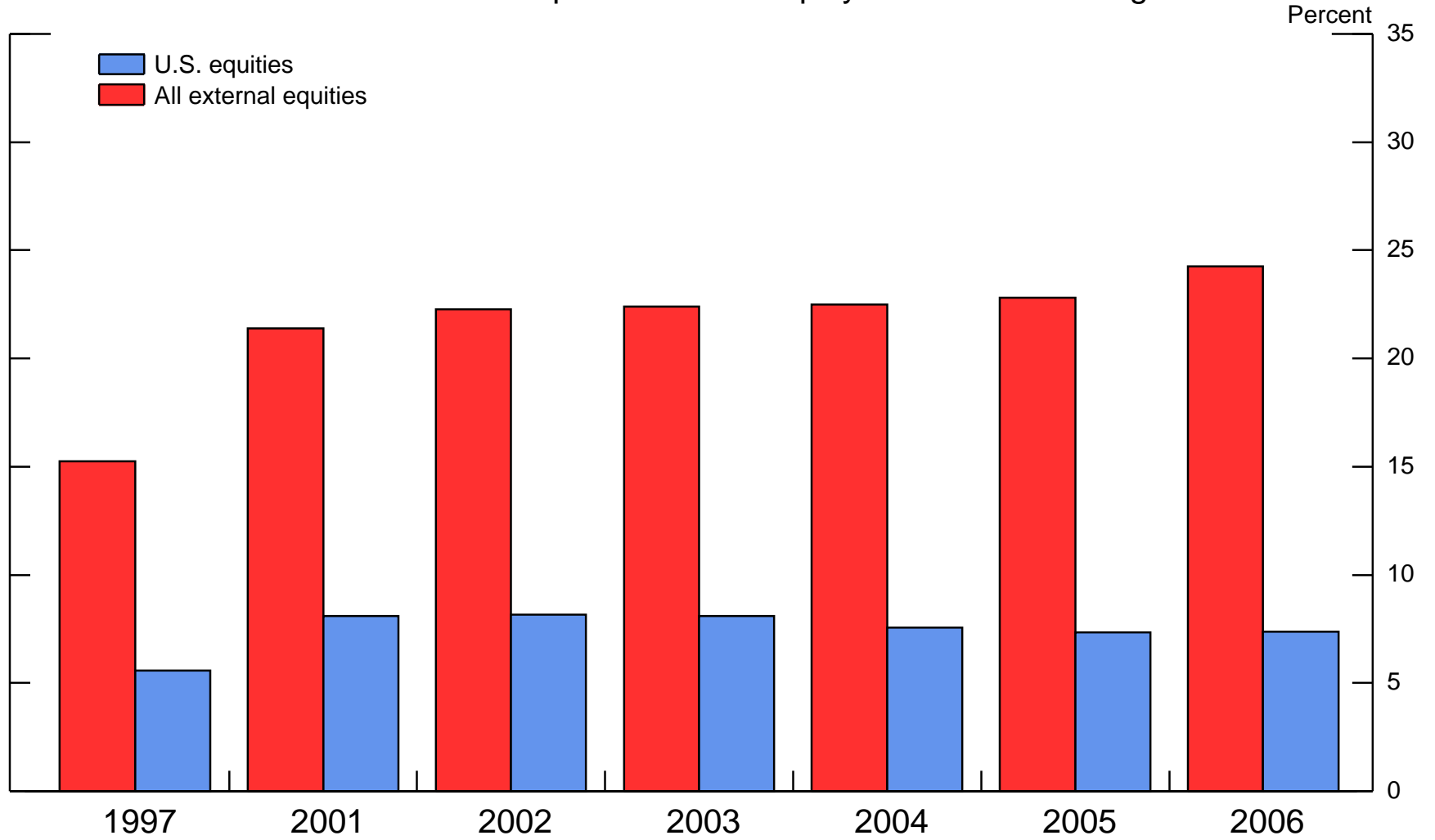

Share of U.S. and All External Bonds in Total Bond Portfolios of Foreign Investors

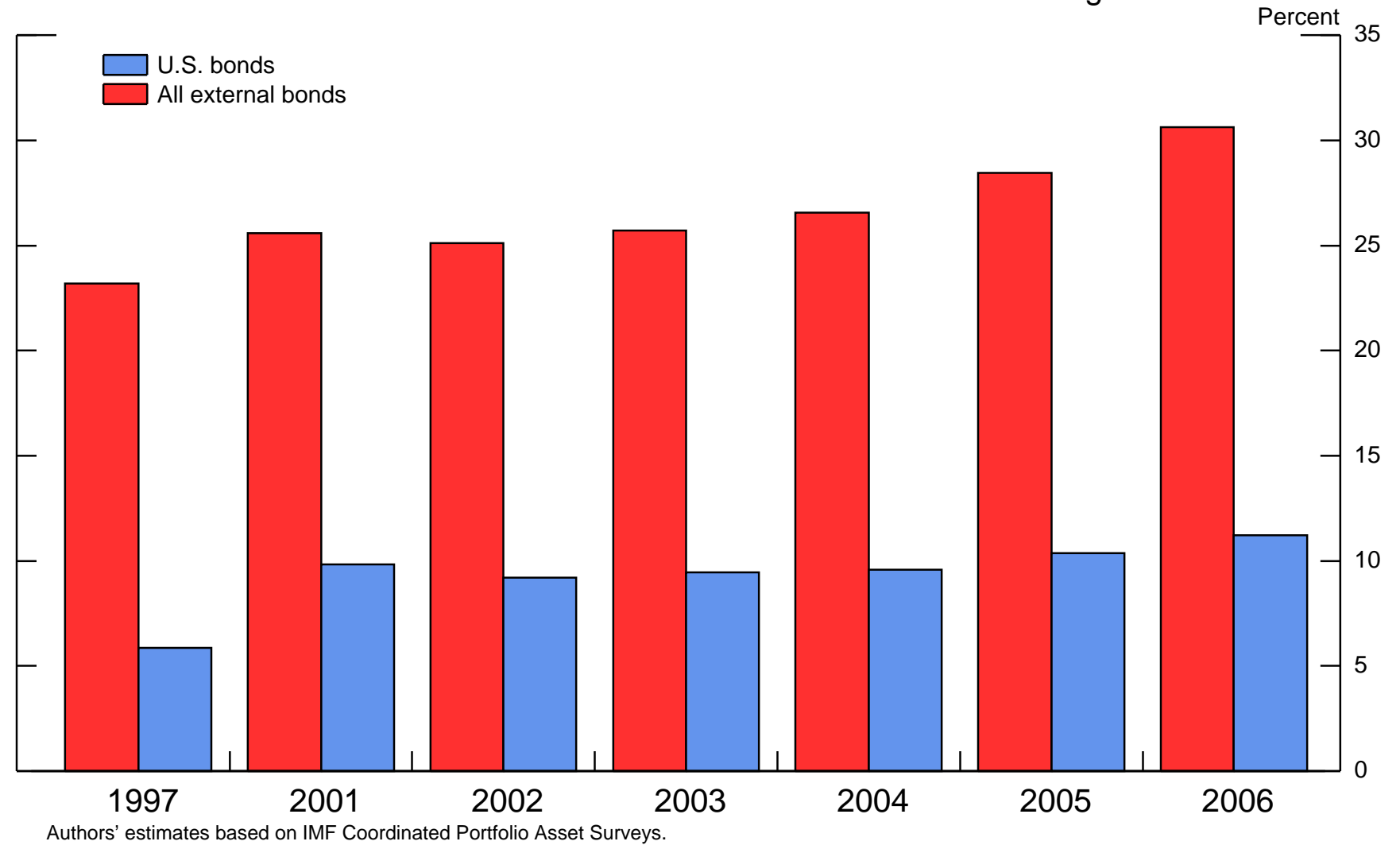




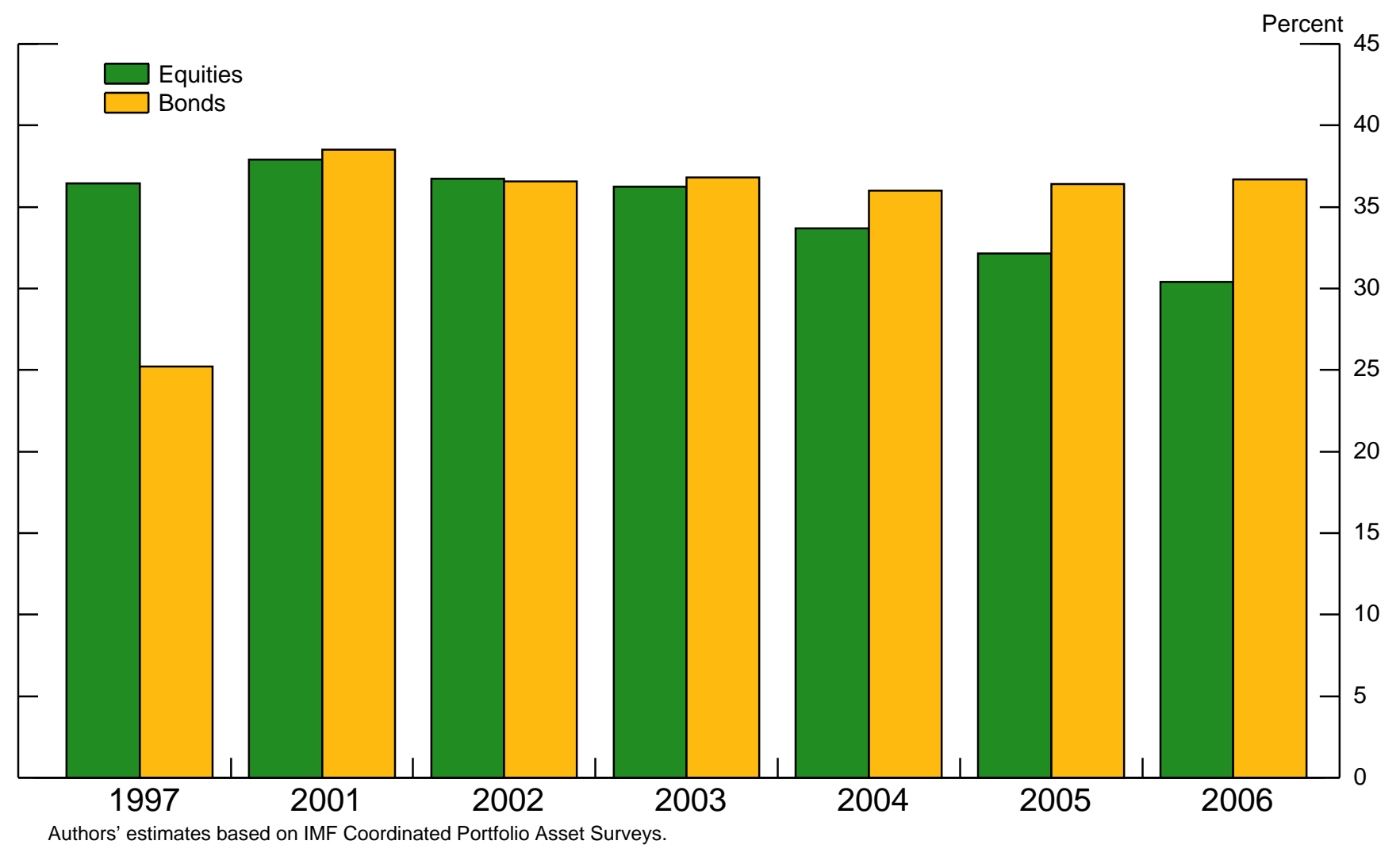


Foreigners' Relative Portfolio Weights in U.S. and All External Equities

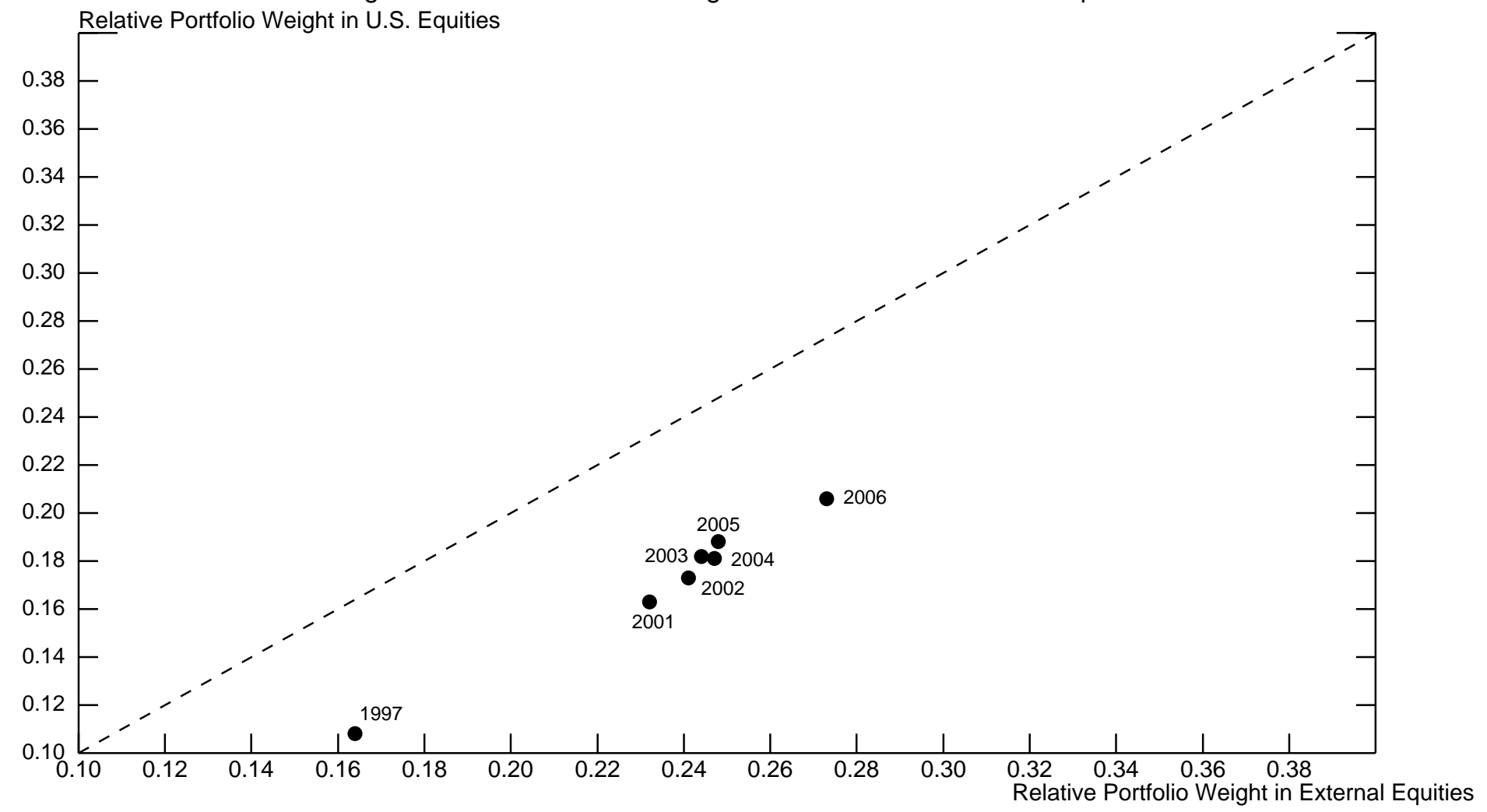

Foreigners' Relative Portfolio Weights in U.S. and All External Bonds

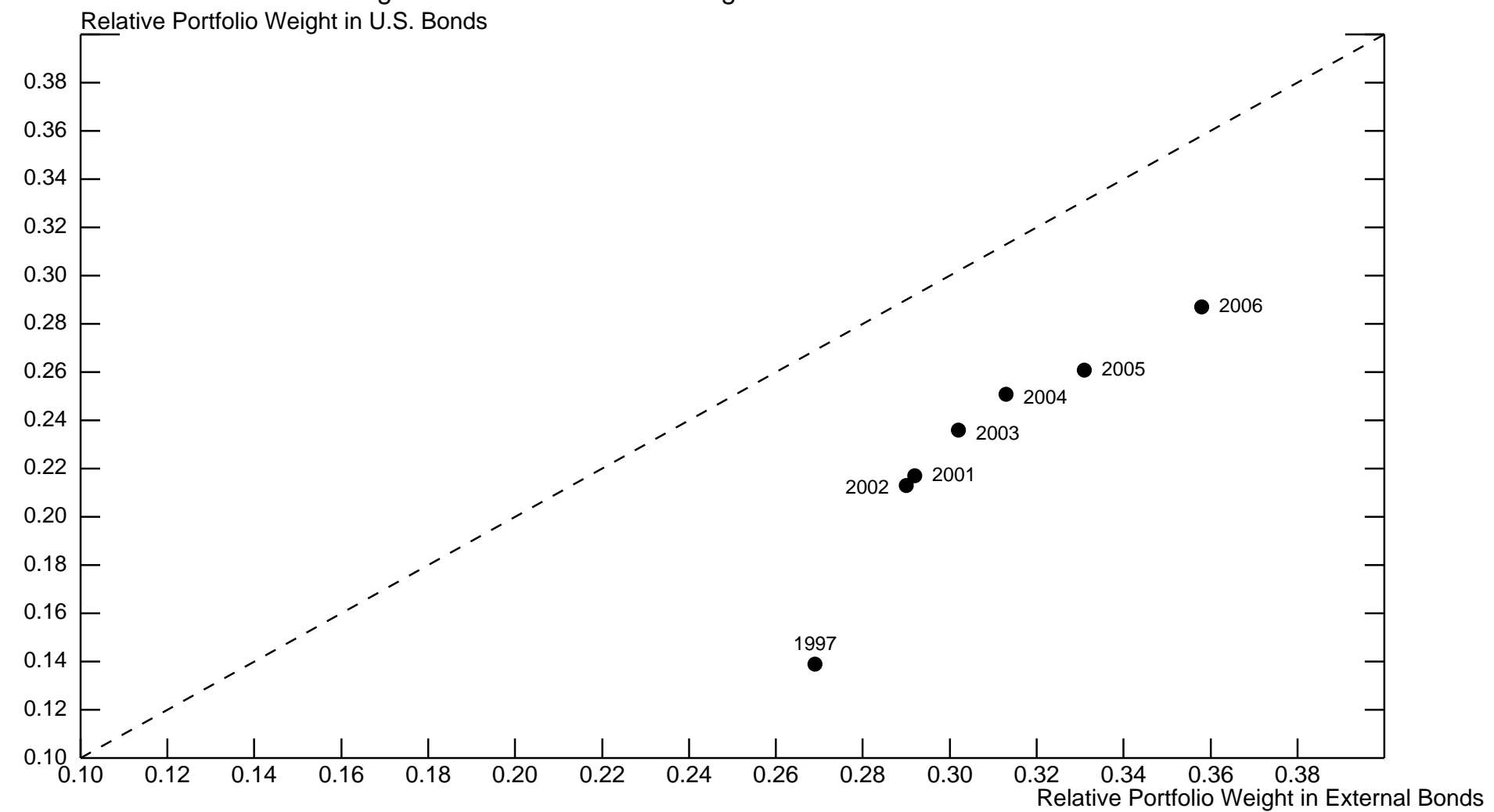




\section{Projections of Foreign Holdings of U.S. Securities}

A. U.S. Market Capitalization

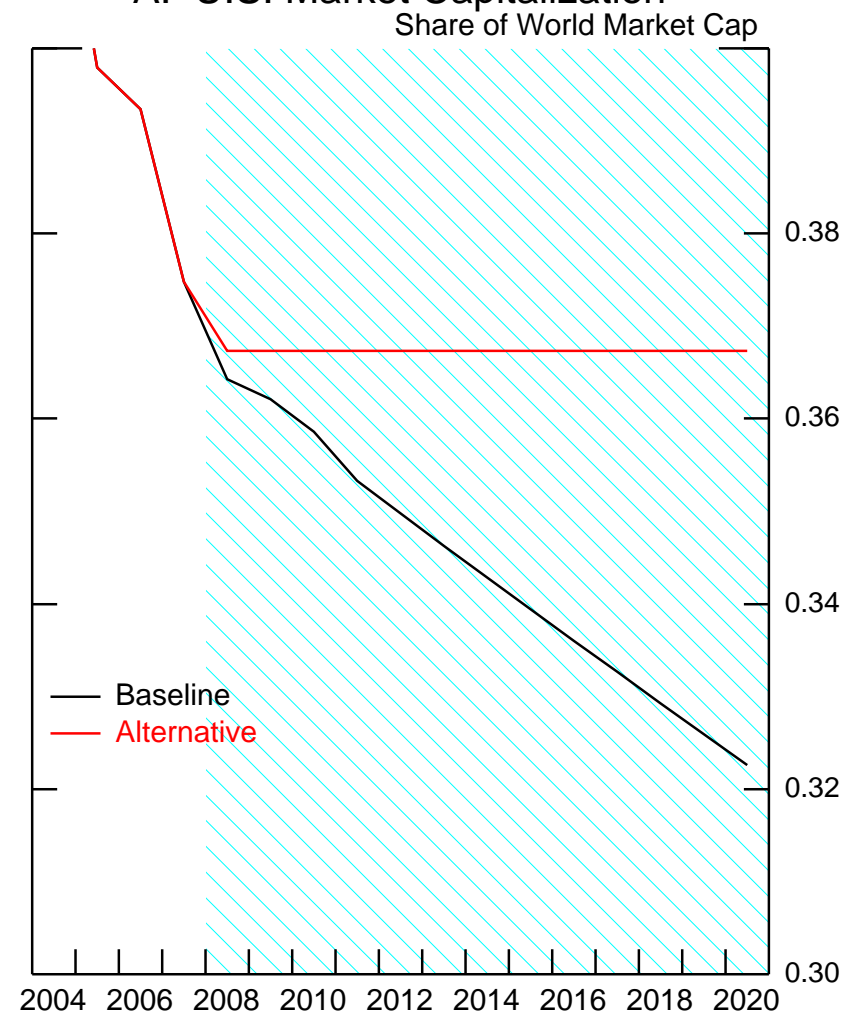

C. U.S. Securities

Share of Total Foreign Portfolio

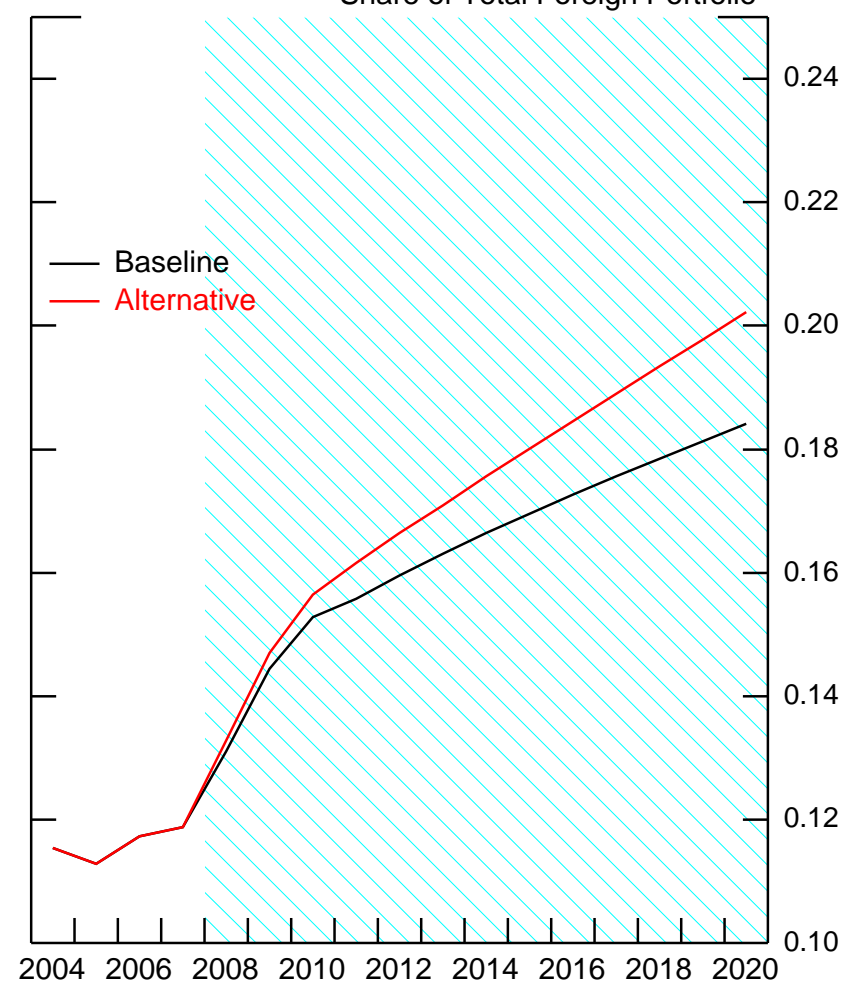

B. Foreign Holdings

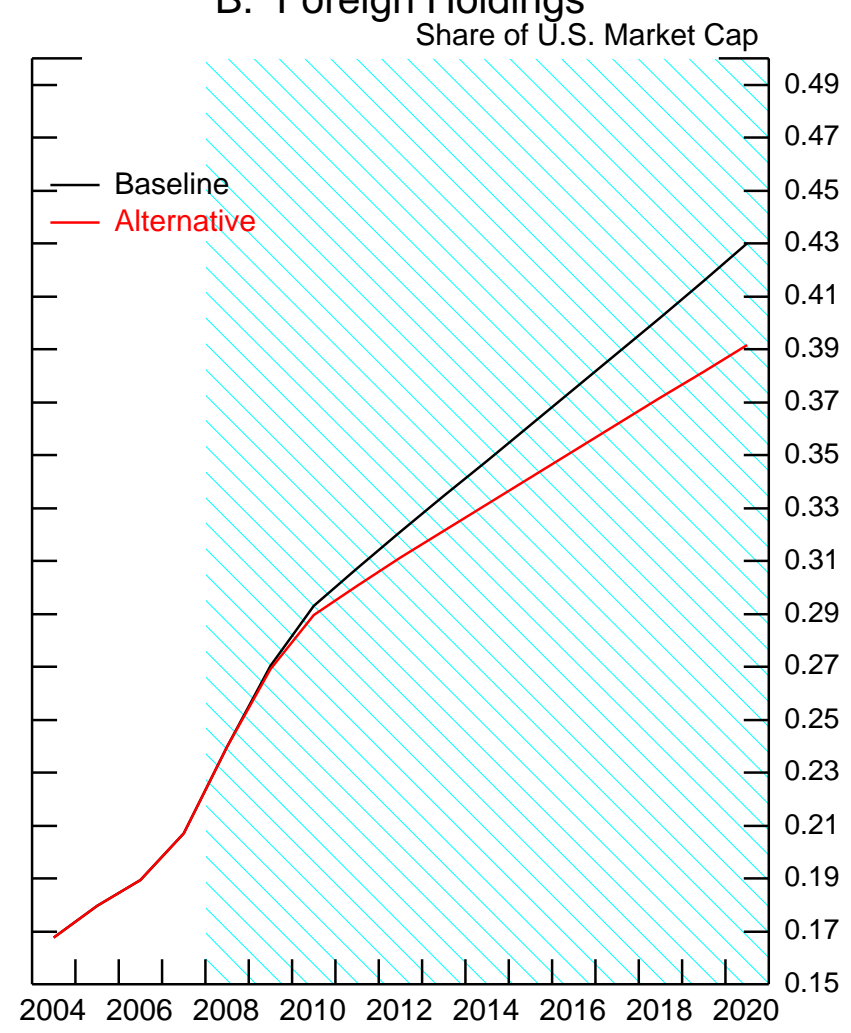

D. U.S. Securities

Relative Weight in Foreign Portfolio

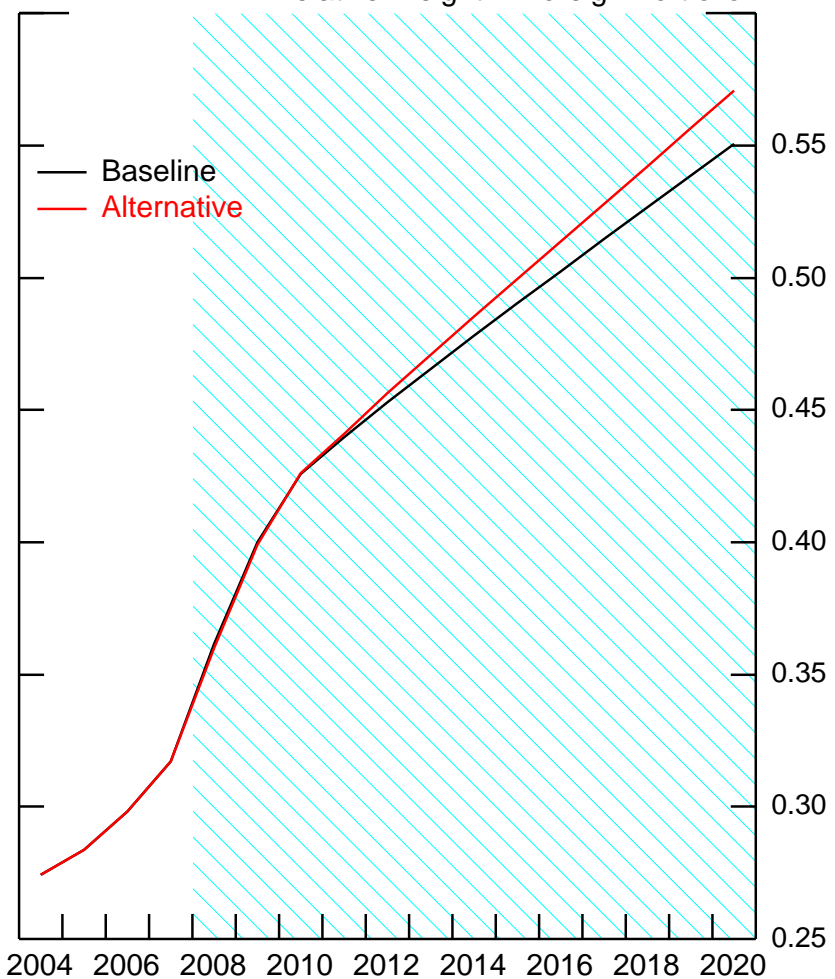


Table 1: Panel Regressions for Interest Rates

Dependent Variable: 10-yr Nominal Government Bond Yields

\begin{tabular}{|c|c|c|c|c|c|c|c|c|c|c|}
\hline & (1) & (2) & (3) $\dagger$ & $(4) \dagger$ & (5) & (6) $\ddagger$ & (7) $\ddagger$ & (8) $\ddagger$ & (9)‡ & $(10) \ddagger$ \\
\hline 10-yr. Int. Rate (-1) & 0.426 & 0.578 & 0.587 & 0.564 & 0.559 & 0.596 & 0.395 & 0.596 & 0.371 & 0.573 \\
\hline SE & 0.041 & 0.059 & 0.058 & 0.060 & 0.062 & 0.064 & 0.048 & 0.063 & 0.047 & 0.066 \\
\hline t-stat & 10.32 & 9.89 & 10.09 & 9.36 & 9.06 & 9.37 & 8.20 & 9.47 & 7.87 & 8.74 \\
\hline 10-yr. Int. Rate (-2) & 0.157 & 0.064 & 0.056 & 0.057 & 0.060 & 0.069 & 0.176 & 0.071 & 0.167 & 0.060 \\
\hline SE & 0.028 & 0.062 & 0.064 & 0.056 & 0.055 & 0.068 & 0.031 & 0.060 & 0.037 & 0.062 \\
\hline t-stat & 5.69 & 1.03 & 0.87 & 1.02 & 1.10 & 1.01 & 5.67 & 1.17 & 4.50 & 0.97 \\
\hline Money Market Int. Rate & 0.246 & 0.198 & 0.194 & 0.204 & 0.211 & 0.195 & 0.238 & 0.170 & 0.265 & 0.206 \\
\hline SE & 0.025 & 0.030 & 0.029 & 0.033 & 0.036 & 0.032 & 0.024 & 0.033 & 0.025 & 0.036 \\
\hline t-stat & 9.82 & 6.64 & 6.82 & 6.12 & 5.87 & 6.12 & 9.90 & 5.19 & 10.72 & 5.69 \\
\hline Inflation & 0.212 & 0.180 & 0.185 & 0.206 & 0.201 & 0.177 & 0.240 & 0.208 & 0.246 & 0.205 \\
\hline SE & 0.042 & 0.066 & 0.065 & 0.063 & 0.067 & 0.066 & 0.038 & 0.062 & 0.044 & 0.064 \\
\hline t-stat & 5.08 & 2.73 & 2.85 & 3.25 & 3.01 & 2.67 & 6.36 & 3.36 & 5.63 & 3.18 \\
\hline Real GDP Growth & 0.077 & 0.060 & 0.064 & 0.071 & 0.066 & 0.049 & 0.089 & 0.045 & 0.110 & 0.057 \\
\hline SE & 0.027 & 0.024 & 0.026 & 0.026 & 0.026 & 0.026 & 0.033 & 0.025 & 0.040 & 0.029 \\
\hline t-stat & 2.88 & 2.54 & 2.47 & 2.72 & 2.49 & 1.89 & 2.72 & 1.78 & 2.76 & 1.94 \\
\hline Int. Rate Volatility & 0.093 & -0.486 & -0.422 & -0.392 & -0.484 & -0.483 & 0.166 & -0.393 & 0.175 & -0.436 \\
\hline SE & 0.408 & 0.289 & 0.288 & 0.308 & 0.296 & 0.324 & 0.480 & 0.326 & 0.526 & 0.319 \\
\hline$t$-stat & 0.23 & -1.68 & -1.47 & -1.27 & -1.64 & -1.49 & 0.35 & -1.21 & 0.33 & -1.37 \\
\hline Fiscal Balance / GDP & -0.005 & -0.025 & -0.031 & -0.022 & -0.019 & -0.025 & -0.004 & 0.001 & -0.035 & -0.026 \\
\hline SE & 0.016 & 0.011 & 0.012 & 0.010 & 0.011 & 0.011 & 0.015 & 0.012 & 0.016 & 0.012 \\
\hline t-stat & -0.34 & -2.17 & -2.61 & -2.14 & -1.71 & -2.25 & -0.25 & 0.09 & -2.13 & -2.23 \\
\hline NIIP / GDP (-1) & & & -0.002 & & & & -0.001 & -0.001 & -0.005 & -0.004 \\
\hline SE & & & 0.002 & & & & 0.001 & 0.001 & 0.003 & 0.002 \\
\hline t-stat & & & -1.60 & & & & -1.25 & -2.25 & -1.90 & -1.92 \\
\hline NIINCOME / GDP (-1) & & & & -0.020 & & & 0.052 & 0.030 & 0.001 & -0.016 \\
\hline SE & & & & 0.059 & & & 0.013 & 0.009 & 0.103 & 0.066 \\
\hline t-stat & & & & -0.35 & & & 4.01 & 3.46 & 0.01 & -0.25 \\
\hline CAB / GDP (-1) & & & & & 0.008 & & -0.011 & -0.001 & -0.003 & 0.015 \\
\hline SE & & & & & 0.012 & & 0.009 & 0.008 & 0.015 & 0.010 \\
\hline t-stat & & & & & 0.61 & & -1.21 & -0.17 & -0.22 & 1.49 \\
\hline Ext. Liab. Variable (-1) & & & & & & 0.020 & -0.004 & -0.001 & 0.006 & 0.013 \\
\hline SE & & & & & & 0.015 & 0.003 & 0.002 & 0.029 & 0.017 \\
\hline t-stat & & & & & & 1.38 & -1.43 & -0.41 & 0.19 & 0.75 \\
\hline Euro & & -0.072 & -0.108 & -0.119 & -0.055 & -0.125 & 0.000 & -0.071 & -0.061 & -0.197 \\
\hline SE & & 0.137 & 0.128 & 0.154 & 0.120 & 0.145 & 0.081 & 0.090 & 0.146 & 0.163 \\
\hline t-stat & & -0.53 & -0.84 & -0.77 & -0.46 & -0.86 & 0.00 & -0.79 & -0.42 & -1.21 \\
\hline Constant & 0.267 & -0.332 & -0.481 & -0.113 & -0.025 & -0.455 & 0.307 & -0.143 & -0.020 & -0.266 \\
\hline SE & 0.130 & 1.058 & 1.064 & 0.952 & 0.937 & 1.028 & 0.150 & 0.711 & 0.433 & 0.916 \\
\hline$t$-stat & 2.05 & -0.31 & -0.45 & -0.12 & -0.03 & -0.44 & 2.05 & -0.20 & -0.05 & -0.29 \\
\hline Time Fixed Effects & No & Yes & Yes & Yes & Yes & Yes & No & Yes & No & Yes \\
\hline Country Fixed Effects & No & Yes & Yes & Yes & Yes & Yes & No & No & Yes & Yes \\
\hline $\mathrm{R}^{\wedge} 2$ & 0.938 & 0.967 & 0.969 & 0.970 & 0.968 & 0.970 & 0.945 & 0.969 & 0.948 & 0.970 \\
\hline SER & 1.060 & 0.810 & 0.796 & 0.787 & 0.814 & 0.791 & 1.022 & 0.798 & 1.020 & 0.798 \\
\hline \# Observations & 541 & 541 & 532 & 518 & 511 & 474 & 438 & 438 & 438 & 438 \\
\hline
\end{tabular}

Except as noted, countries included are Australia, Austria, Belgium, Canada, Denmark, Finland, France, Germany, Greece, Iceland, Ireland, Italy, Japan, Netherlands, New Zealand, Norway, Portugal, Spain, Sweden, Switzerland, the United Kingdom, and the United States.

$\dagger$ Excludes Iceland.

‡ Excludes Canada, Iceland, and Italy. 
Table 2: Panel Regressions for Exchange Rates

Dependent Variable: Real Effective Exchange Rate as Percent Deviation from Sample Mean (Note: Means calculated by country.) (Note: REER is home relative to foreign. An increase is an appreciation.)

\begin{tabular}{|c|c|c|c|c|c|c|c|c|c|c|}
\hline & (1) & (2) & (3) $\dagger$ & $(4) \dagger$ & (5) & (6) $\ddagger$ & $(7) \ddagger$ & (8) $\ddagger$ & (9) $\ddagger$ & $(10) \ddagger$ \\
\hline REER Pct. Dev. (-1) & 1.066 & 1.053 & 1.066 & 1.078 & 1.043 & 1.046 & 1.087 & 1.097 & 1.021 & 1.026 \\
\hline SE & 0.035 & 0.035 & 0.031 & 0.039 & 0.036 & 0.026 & 0.044 & 0.037 & 0.044 & 0.032 \\
\hline t-stat & 30.32 & 30.29 & 34.81 & 27.90 & 28.75 & 40.73 & 24.86 & 29.84 & 23.40 & 32.09 \\
\hline REER Pct. Dev. (-2) & -0.333 & -0.321 & -0.331 & -0.330 & -0.313 & -0.317 & -0.334 & -0.327 & -0.326 & -0.311 \\
\hline SE & 0.036 & 0.034 & 0.031 & 0.037 & 0.038 & 0.035 & 0.047 & 0.039 & 0.054 & 0.045 \\
\hline$t$-stat & -9.27 & -9.37 & -10.55 & -8.83 & -8.27 & -9.13 & -7.06 & -8.29 & -6.05 & -6.91 \\
\hline Money Market Int. Rate & 0.178 & 0.365 & 0.380 & 0.363 & 0.371 & 0.421 & 0.198 & 0.370 & 0.254 & 0.417 \\
\hline SE & 0.081 & 0.162 & 0.167 & 0.169 & 0.159 & 0.178 & 0.090 & 0.145 & 0.093 & 0.170 \\
\hline$t$-stat & 2.19 & 2.25 & 2.28 & 2.16 & 2.33 & 2.37 & 2.20 & 2.56 & 2.72 & 2.45 \\
\hline Inflation & -0.242 & -0.453 & -0.427 & -0.359 & -0.471 & -0.440 & -0.230 & -0.308 & -0.334 & -0.426 \\
\hline SE & 0.051 & 0.136 & 0.131 & 0.150 & 0.146 & 0.131 & 0.086 & 0.131 & 0.098 & 0.143 \\
\hline t-stat & -4.71 & -3.33 & -3.27 & -2.40 & -3.23 & -3.36 & -2.68 & -2.34 & -3.42 & -2.97 \\
\hline Real GDP Growth & -0.173 & -0.332 & -0.344 & -0.332 & -0.337 & -0.274 & -0.111 & -0.157 & -0.167 & -0.234 \\
\hline SE & 0.142 & 0.173 & 0.192 & 0.193 & 0.198 & 0.202 & 0.185 & 0.190 & 0.197 & 0.214 \\
\hline t-stat & -1.22 & -1.92 & -1.80 & -1.72 & -1.70 & -1.36 & -0.60 & -0.83 & -0.85 & -1.09 \\
\hline Int. Rate Volatility & -0.458 & -0.937 & -0.961 & -0.557 & -0.871 & -1.314 & -0.339 & -0.244 & -0.329 & -0.692 \\
\hline SE & 0.559 & 1.093 & 1.146 & 1.225 & 1.022 & 1.226 & 0.549 & 0.944 & 0.821 & 1.202 \\
\hline$t$-stat & -0.82 & -0.86 & -0.84 & -0.45 & -0.85 & -1.07 & -0.62 & -0.26 & -0.40 & -0.58 \\
\hline Fiscal Balance / GDP & 0.014 & 0.094 & 0.116 & 0.073 & 0.030 & 0.185 & 0.072 & 0.118 & 0.048 & 0.125 \\
\hline SE & 0.050 & 0.108 & 0.107 & 0.107 & 0.097 & 0.118 & 0.067 & 0.061 & 0.113 & 0.127 \\
\hline t-stat & 0.28 & 0.87 & 1.09 & 0.68 & 0.31 & 1.57 & 1.07 & 1.93 & 0.43 & 0.98 \\
\hline NIIP / GDP (-1) & & & 0.016 & & & & 0.013 & 0.017 & 0.011 & 0.013 \\
\hline SE & & & 0.009 & & & & 0.007 & 0.007 & 0.014 & 0.014 \\
\hline$t$-stat & & & 1.76 & & & & 1.81 & 2.66 & 0.78 & 0.96 \\
\hline NIINCOME / GDP (-1) & & & & 0.356 & & & -0.052 & -0.067 & 0.552 & 0.486 \\
\hline SE & & & & 0.200 & & & 0.083 & 0.087 & 0.275 & 0.261 \\
\hline t-stat & & & & 1.78 & & & -0.62 & -0.76 & 2.01 & 1.86 \\
\hline CAB / GDP (-1) & & & & & -0.002 & & -0.068 & -0.077 & -0.191 & -0.166 \\
\hline SE & & & & & 0.103 & & 0.080 & 0.092 & 0.115 & 0.138 \\
\hline$t$-stat & & & & & -0.02 & & -0.86 & -0.84 & -1.66 & -1.20 \\
\hline Ext. Liab. Variable (-1) & & & & & & 0.271 & 0.001 & 0.012 & 0.509 & 0.486 \\
\hline SE & & & & & & 0.129 & 0.021 & 0.023 & 0.233 & 0.251 \\
\hline t-stat & & & & & & 2.10 & 0.05 & 0.52 & 2.19 & 1.93 \\
\hline Euro & & 0.099 & 0.362 & 0.524 & 0.148 & -0.486 & 0.632 & 0.294 & -0.095 & -0.138 \\
\hline SE & & 0.837 & 0.858 & 0.897 & 0.849 & 1.106 & 0.657 & 0.759 & 0.946 & 1.283 \\
\hline t-stat & & 0.12 & 0.42 & 0.58 & 0.17 & -0.44 & 0.96 & 0.39 & -0.10 & -0.11 \\
\hline Constant & 0.677 & -0.598 & -0.513 & -0.755 & -0.344 & -2.039 & 0.310 & -1.746 & -0.668 & -2.507 \\
\hline SE & 0.673 & 2.090 & 2.146 & 2.377 & 2.268 & 2.452 & 0.754 & 1.218 & 1.426 & 2.664 \\
\hline t-stat & 1.01 & -0.29 & -0.24 & -0.32 & -0.15 & -0.83 & 0.41 & -1.43 & -0.47 & -0.94 \\
\hline Time Fixed Effects & No & Yes & Yes & Yes & Yes & Yes & No & Yes & No & Yes \\
\hline Country Fixed Effects & No & Yes & Yes & Yes & Yes & Yes & No & No & Yes & Yes \\
\hline $\mathrm{R}^{\wedge} 2$ & 0.7116 & 0.7705 & 0.7749 & 0.7864 & 0.7701 & 0.7741 & 0.7301 & 0.7771 & 0.7463 & 0.7901 \\
\hline SER & 5.0163 & 4.7281 & 4.6858 & 4.5901 & 4.8073 & 4.6942 & 4.9430 & 4.6687 & 4.9065 & 4.6473 \\
\hline \# Observations & 497 & 497 & 488 & 480 & 473 & 434 & 404 & 404 & 404 & 404 \\
\hline
\end{tabular}

Except as noted, countries included are Australia, Austria, Belgium, Canada, Denmark, Finland, France, Germany, Greece, Iceland, Ireland, Italy, Japan, Netherlands, New Zealand, Norway, Portugal, Spain, Sweden, Switzerland, the United Kingdom, and the United States.

$\dagger$ Excludes Iceland.

$\ddagger$ Excludes Canada, Iceland, and Italy. 
Table 3: Panel Regressions for Exchange Rates

Dependent Variable: Real Effective Exchange Rate Percent Change (Note: REER is home relative to foreign. An increase is an appreciation.)

\begin{tabular}{|c|c|c|c|c|c|c|c|c|c|c|}
\hline & (1) & (2) & (3) $\dagger$ & (4) $\dagger$ & (5) & (6) $\ddagger$ & (7) $\ddagger$ & (8) $\ddagger$ & (9)‡ & $(10) \ddagger$ \\
\hline REER Pct Change $(-1)$ & 0.185 & 0.185 & 0.205 & 0.207 & 0.165 & 0.206 & 0.201 & 0.214 & 0.180 & 0.179 \\
\hline SE & 0.048 & 0.037 & 0.031 & 0.038 & 0.040 & 0.037 & 0.062 & 0.044 & 0.064 & 0.044 \\
\hline t-stat & 3.82 & 4.93 & 6.58 & 5.43 & 4.11 & 5.52 & 3.22 & 4.86 & 2.83 & 4.09 \\
\hline REER Pct Change (-2) & -0.112 & -0.131 & -0.137 & -0.138 & -0.126 & -0.162 & -0.142 & -0.150 & -0.158 & -0.172 \\
\hline SE & 0.026 & 0.030 & 0.030 & 0.031 & 0.032 & 0.029 & 0.026 & 0.028 & 0.030 & 0.033 \\
\hline t-stat & -4.27 & -4.35 & -4.49 & -4.49 & -3.97 & -5.57 & -5.44 & -5.38 & -5.35 & -5.28 \\
\hline Money Market Int. Rate & 0.162 & 0.356 & 0.387 & 0.356 & 0.443 & 0.398 & 0.206 & 0.345 & 0.285 & 0.476 \\
\hline SE & 0.055 & 0.182 & 0.186 & 0.179 & 0.183 & 0.207 & 0.077 & 0.167 & 0.103 & 0.202 \\
\hline t-stat & 2.95 & 1.96 & 2.08 & 1.99 & 2.42 & 1.92 & 2.69 & 2.07 & 2.76 & 2.35 \\
\hline Inflation & -0.046 & -0.331 & -0.296 & -0.237 & -0.339 & -0.312 & -0.017 & -0.155 & -0.069 & -0.313 \\
\hline SE & 0.086 & 0.128 & 0.126 & 0.122 & 0.129 & 0.128 & 0.068 & 0.083 & 0.106 & 0.130 \\
\hline t-stat & -0.53 & -2.59 & -2.36 & -1.95 & -2.62 & -2.44 & -0.25 & -1.87 & -0.66 & -2.41 \\
\hline Real GDP Growth & 0.024 & -0.084 & -0.069 & -0.052 & -0.151 & 0.022 & 0.063 & 0.051 & 0.038 & 0.004 \\
\hline SE & 0.172 & 0.199 & 0.215 & 0.215 & 0.234 & 0.226 & 0.236 & 0.221 & 0.250 & 0.250 \\
\hline t-stat & 0.14 & -0.42 & -0.32 & -0.24 & -0.65 & 0.10 & 0.27 & 0.23 & 0.15 & 0.02 \\
\hline Int. Rate Volatility & -1.201 & -0.972 & -0.995 & -0.380 & -1.416 & -0.851 & -0.795 & -0.221 & -1.164 & -0.734 \\
\hline SE & 0.633 & 1.082 & 1.143 & 1.044 & 1.171 & 1.297 & 0.405 & 0.769 & 0.644 & 1.213 \\
\hline t-stat & -1.90 & -0.90 & -0.87 & -0.36 & -1.21 & -0.66 & -1.96 & -0.29 & -1.81 & -0.60 \\
\hline Fiscal Balance / GDP & 0.150 & 0.379 & 0.387 & 0.351 & 0.343 & 0.486 & 0.203 & 0.261 & 0.317 & 0.458 \\
\hline SE & 0.072 & 0.164 & 0.151 & 0.164 & 0.143 & 0.189 & 0.086 & 0.084 & 0.150 & 0.177 \\
\hline t-stat & 2.09 & 2.31 & 2.56 & 2.15 & 2.40 & 2.57 & 2.35 & 3.10 & 2.11 & 2.59 \\
\hline NIIP / GDP (-1) & & & 0.007 & & & & 0.000 & 0.006 & 0.001 & 0.006 \\
\hline SE & & & 0.013 & & & & 0.007 & 0.006 & 0.019 & 0.015 \\
\hline t-stat & & & 0.51 & & & & 0.07 & 1.03 & 0.05 & 0.44 \\
\hline NIINCOME / GDP (-1) & & & & 0.019 & & & -0.032 & -0.046 & -0.056 & -0.284 \\
\hline SE & & & & 0.242 & & & 0.060 & 0.070 & 0.250 & 0.240 \\
\hline t-stat & & & & 0.08 & & & -0.54 & -0.66 & -0.22 & -1.19 \\
\hline CAB / GDP (-1) & & & & & 0.254 & & 0.100 & 0.078 & 0.154 & 0.194 \\
\hline SE & & & & & 0.112 & & 0.057 & 0.079 & 0.077 & 0.124 \\
\hline t-stat & & & & & 2.26 & & 1.75 & 0.99 & 2.00 & 1.57 \\
\hline Ext. Liab. Variable (-1) & & & & & & -0.065 & 0.012 & 0.023 & 0.178 & 0.186 \\
\hline SE & & & & & & 0.058 & 0.019 & 0.022 & 0.139 & 0.179 \\
\hline t-stat & & & & & & -1.12 & 0.66 & 1.05 & 1.28 & 1.04 \\
\hline Euro & & -0.255 & -0.168 & -0.272 & 0.500 & -0.232 & 0.611 & 0.294 & 0.374 & -0.226 \\
\hline SE & & 0.801 & 0.779 & 0.812 & 0.952 & 0.958 & 0.458 & 0.571 & 0.639 & 1.033 \\
\hline$t$-stat & & -0.32 & -0.22 & -0.34 & 0.53 & -0.24 & 1.33 & 0.52 & 0.59 & -0.22 \\
\hline Constant & 0.038 & -4.118 & -4.505 & -5.150 & -2.471 & -4.973 & -0.886 & -4.995 & -2.187 & -5.132 \\
\hline SE & 0.654 & 3.045 & 3.020 & 2.982 & 3.569 & 3.317 & 0.770 & 2.648 & 1.601 & 3.560 \\
\hline t-stat & 0.06 & -1.35 & -1.49 & -1.73 & -0.69 & -1.50 & -1.15 & -1.89 & -1.37 & -1.44 \\
\hline Time Fixed Effects & No & Yes & Yes & Yes & Yes & Yes & No & Yes & No & Yes \\
\hline Country Fixed Effects & No & Yes & Yes & Yes & Yes & Yes & No & No & Yes & Yes \\
\hline $\mathrm{R}^{\wedge} 2$ & 0.0557 & 0.2750 & 0.2849 & 0.2987 & 0.2821 & 0.2839 & 0.0835 & 0.2758 & 0.1039 & 0.3038 \\
\hline SER & 5.5589 & 5.1462 & 5.0894 & 4.8938 & 5.1916 & 5.0676 & 5.2979 & 4.8912 & 5.3659 & 4.9215 \\
\hline \# Observations & 488 & 488 & 479 & 471 & 464 & 427 & 397 & 397 & 397 & 397 \\
\hline
\end{tabular}

Except as noted, countries included are Australia, Austria, Belgium, Canada, Denmark, Finland, France, Germany, Greece, Iceland, Ireland, Italy, Japan, Netherlands, New Zealand, Norway, Portugal, Spain, Sweden, Switzerland, the United Kingdom, and the United States.

$\dagger$ Excludes Iceland

‡ Excludes Canada, Iceland, and Italy. 
Table 4: Standard Determinants of Current Account / GDP

Per Capita GDP

\begin{tabular}{llll}
1 & 2 & 3 & 4 \\
\hline 0.003 & 0.005 & 0.010 & 0.011
\end{tabular}

$\Delta$ Growth

$3.200 \quad 3.806$

$4.475 \quad 4.628$

$\begin{array}{llll}0.032 & 0.066 & -0.063 & -0.010\end{array}$

$\begin{array}{llll}0.396 & 1.043 & -0.436 & -0.102\end{array}$

Fiscal Balance

$\begin{array}{llll}0.189 & 0.185 & 0.214 & 0.207\end{array}$

$\begin{array}{lrrrr} & 2.864 & 3.333 & 2.616 & 3.063 \\ \text { NFA } & \mathbf{0 . 0 1 8} & \mathbf{0 . 0 1 6} & \mathbf{0 . 0 1 3} & \mathbf{0 . 0 1 1} \\ & 2.765 & 2.603 & 2.526 & 2.713 \\ \text { Age Dependency Ratio } & -\mathbf{0 . 0 2 5} & -0.010 & -\mathbf{0 . 0 6 8} & -\mathbf{0 . 0 4 1} \\ & -1.954 & -0.574 & -3.233 & -1.627 \\ \text { Oil Balance / GDP } & \mathbf{0 . 1 5 8} & \mathbf{0 . 1 5 6} & \mathbf{0 . 1 6 5} & \mathbf{0 . 1 6 8} \\ & 3.130 & 3.038 & 2.452 & 2.367 \\ \text { Openness } & \mathbf{0 . 0 1 2} & 0.006 & 0.010 & 0.000 \\ & 1.996 & 1.099 & 1.012 & 0.064 \\ \text { Governance Indicators } & & & -\mathbf{0 . 0 1 8} & -\mathbf{0 . 0 1 5} \\ & & & -2.379 & -2.133 \\ \text { U.S.(1997 - 2006) } & & -0.060 & & -\mathbf{0 . 0 7 7} \\ & & -3.752 & & -4.174 \\ \text { Developing Asia (1997-2006) } & & \mathbf{0 . 0 4 7} & & \mathbf{0 . 0 4 7} \\ & & 4.666 & & 8.520 \\ \text { \#Obs } & & & & \\ \text { R^2 } & & & & \\ \text { SER } & 346 & 346 & 221 & 221 \\ & 0.313 & 0.364 & 0.372 & 0.445 \\ & 0.035 & 0.034 & 0.037 & 0.034\end{array}$

Panel regression with unreported constant and period fixed effects.

84 cross-sections and 5 periods.

t-statistic reported underneath coefficient

Bold indicates signifance at the 10 percent level.

Developing Asia includes China, Hong Kong, Indonesia, Korea, Malaysia,

Philippines, Taiwan, and Thailand 